UNIVERSIDADE DE SÃO PAULO

FACULDADE DE ECONOMIA, ADMINISTRAÇÃO E CONTABILIDADE DEPARTAMENTO DE CONTABILIDADE E ATUÁRIA

PROGRAMA DE PÓS-GRADUAÇÃO EM CONTROLADORIA E CONTABILIDADE

CRISTINA LINARES CINTRA DE CARVALHO

PESSOAS COM DEFICIÊNCIA NO ENSINO SUPERIOR: PERCEPÇÕES DOS ALUNOS

SÃo PAULO 
Prof. Dr. Marco Antônio Zago

Reitor da Universidade de São Paulo

Prof. Dr. Adalberto Américo Fischmann

Diretor da Faculdade de Economia, Administração, Contabilidade e Atuária

Prof. Dr. Gerlando Augusto Sampaio Franco de Lima

Chefe do Departamento de Contabilidade e Atuária

Prof. Dr. Andson Braga de Aguiar Coordenador do Programa de Pós-Graduação em Controladoria e Contabilidade 
Dissertação apresentada à Faculdade de Economia, Administração e Contabilidade da Universidade de São Paulo, como parte dos requisitos para obtenção do grau de Mestre em Controladoria e Contabilidade

Orientador: Prof. Dr. Edson Luiz Riccio

\section{SÃO PAULO}


Autorizo a reprodução e divulgação total ou parcial deste trabalho, por qualquer meio convencional ou eletrônico, para fins de estudo e pesquisa, desde que citada a fonte.

FICHA CATALOGRÁFICA

Elaborada pela Seção de Processamento Técnico do SBD/FEA/USP

Carvalho, Cristina Linares Cintra de

Pessoas com deficiência no ensino superior: percepções dos alunos I

Cristina Linares Cintra de Carvalho. -- São Paulo, 2015.

$95 \mathrm{p}$.

Dissertação (Mestrado) - Universidade de São Paulo, 2015.

Orientador: Édson Luiz Riccio.

1. Deficientes 2. Contabilidade 3. Educação especial 4. Inclusão escolar I. Universidade de São Paulo. Faculdade de Economia, Administração e Contabilidade II. Título.

CDD -305.908 
A minha filha Bianca, a qual nem existia quando iniciei este trabalho, e que hoje ocupa todos os meus pensamentos. 


\section{AGRADECIMENTOS}

Em primeiro lugar a Deus, que possibilitou que eu chegasse a esta etapa da vida.

Ao Prof. Dr. Edson Luiz Riccio pela atenção e apoio durante o processo de elaboração deste trabalho.

A Prof. Dra. Silvia Pereira de Castro Casa Nova por me inspirar a seguir na docência e mostrar que é possível vencer obstáculos aparentemente instransponíveis.

A Prof. Dra. Rosângela Gavioli Prieto por abrir um novo horizonte em termos de pesquisa e apresentar questões tão indispensáveis sobre o tema.

A minha família, que foi essencial para o desenvolvimento deste trabalho, e sem a qual eu não teria condições para fazê-lo.

A todos os alunos com deficiência que contribuíram com esta pesquisa e que lutam por seus direitos de cidadãos, buscando uma sociedade mais justa.

Por fim, aos amigos da academia pelo incentivo, ideias e apoio nas horas difíceis. 


\section{RESUMO}

Carvalho, C L C. (2015). Pessoas com deficiência no ensino superior: percepções dos alunos. Dissertação de Mestrado, Faculdade de Economia, Administração e Contabilidade, Universidade de São Paulo, São Paulo.

Cerca de 10\% de toda a população mundial, aproximadamente 650 milhões de pessoas vivem com alguma deficiência, transtorno global de desenvolvimento (TGD) ou com alta habilidade/ superdotação (AH/SD) de acordo com a Organização das Nações Unidas (2011). Em todo o mundo estas pessoas têm baixas perspectivas de escolaridade, de participação na economia e nos programas de saúde. O presente trabalho tem por objetivo entender a trajetória de vida de alunos com deficiência graduados e com alguma passagem pela contabilidade, seja através da faculdade ou através do ambiente de trabalho, apoiando-se em relatos da vida profissional, educacional, obstáculos e facilitadores encontrados. Buscou-se através da história oral, pontos convergentes entre os relatos e sugestões para a melhoria das condições nas universidades para acesso e permanência da pessoa com deficiência. O trabalho desenvolve-se a partir de uma breve retrospectiva na história das pessoas com deficiência, aborda as políticas públicas brasileiras sobre o tema, traz dados sobre educação superior das pessoas com deficiência e por fim, entrevista os alunos encontrados. Verificou-se, assim, que é crescente o número de alunos com deficiência no ensino superior e que as condições nas instituições de ensino melhoraram nos últimos anos. No entanto os facilitadores apontados pelos entrevistados continuam fora das instituições, tais como amigos de sala. Além disto, a divulgação dos serviços existentes deve ser mais difundida, a fim de que todos tenham consciência de seus direitos. Conclui-se que apesar do enorme avanço ocorrido nas últimas décadas, ainda há muito a ser desenvolvido dentro das universidades para que se possa garantir o direito de educação à todos.

Palavras-chave: Pessoas com Deficiência. Educação Superior. Necessidades Especiais. Inclusão. Alunos com Deficiência. 


\begin{abstract}
Carvalho, C L C. (2015). People with disabilities in higher education: perceptions of students. Master's thesis, Faculdade de Economia, Administração e Contabilidade, Universidade de São Paulo, São Paulo.

About $10 \%$ of people over the world, almost 650 million, have some disabilities, pervasive developmental disorder or intellectual giftedness, according to United Nations (2011). These people have low schooling perspective, economics participation and health programs. This study aims to understand the trajectory of life of students with disabilities and graduates with a passage for the accounting, either through college or through the work environment, relying on reports vocational educational life; obstacles encountered and facilitators. It tried to through life history, convergence between the reports and suggestions for improving conditions in the universities to access and retention of people with disabilities. The work develops from a brief setback in the history of people with disabilities, addresses the Brazilian public policies on the subject, brings data on higher education of persons with disabilities and ultimately interview the students found. It was thus that an increasing number of students with disabilities in higher education and that the conditions in educational institutions have evolved over the last decades. However facilitators appointed by the interviewees remain out of institutions, such as partners. In addition, disclosure of existing services should be expanded, so that all know their rights. It's possible conclude that despite the impressive progress in recent decades, much remains to be developed within universities so that we can ensure the right to education for all.
\end{abstract}

Keywords: People with Disabilities. Higher Education. Special Needs. Inclusion. Students with Disabilities. 


\section{SUMÁRIO}

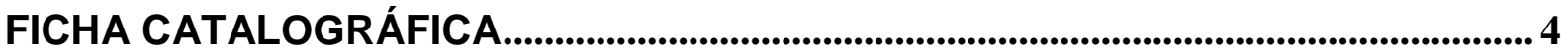

LISTA DE ABREVIATURAS ................................................................................10

LISTA DE FIGURAS ……..................................................................................................... 11

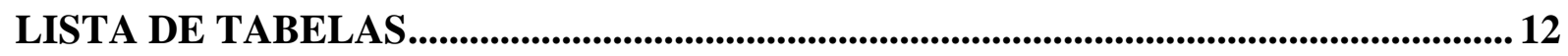

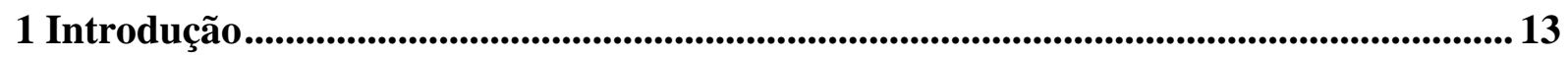

2 Revisão de Literatura......................................................................................................... 15

2.1 História das pessoas com deficiência ..................................................................... 15

2.2 Definição e Legislação sobre pessoas com deficiência................................................... 17

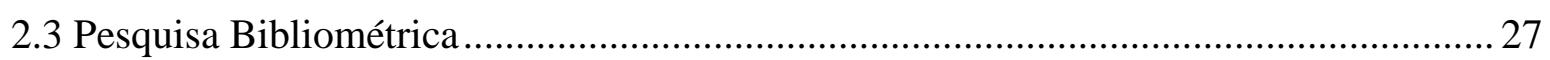

2.4 Contabilidade e Pessoas com Deficiência ................................................................. 34

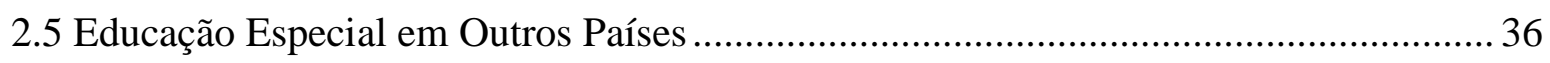

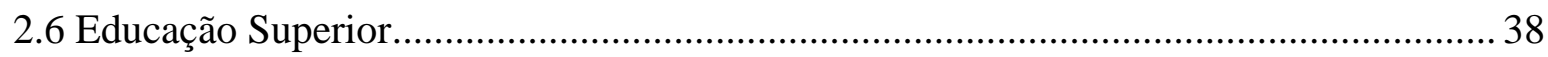

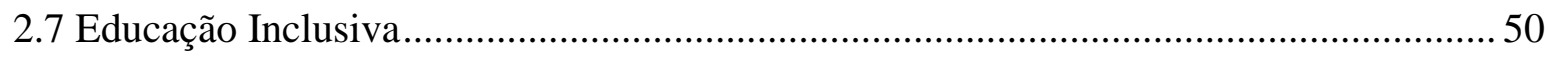

3 Metodologia..............................................................................................................6 60

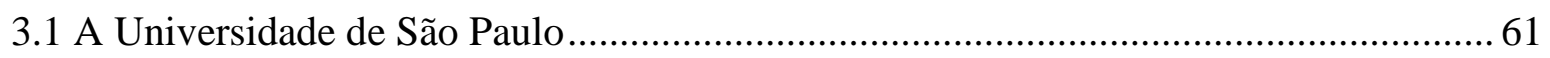

3.2 A Faculdade de Economia Administração e Contabilidade (FEA)................................... 62

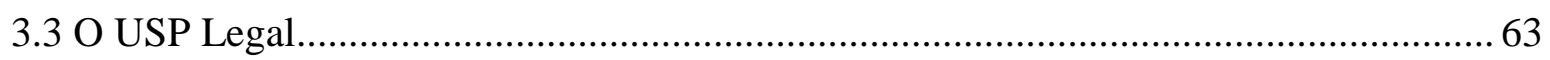

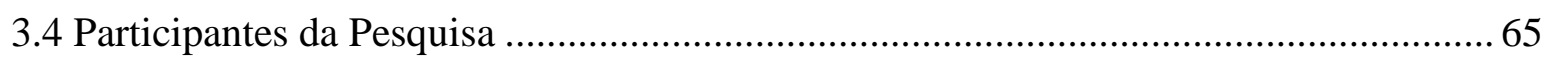

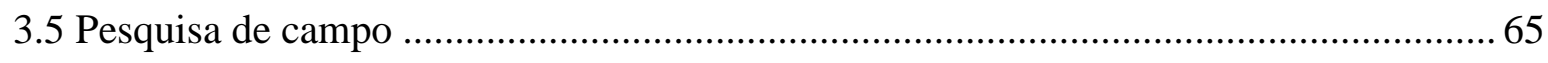

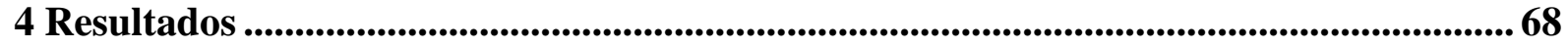

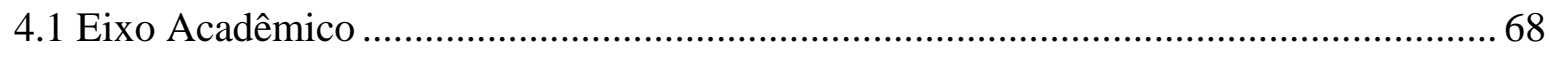

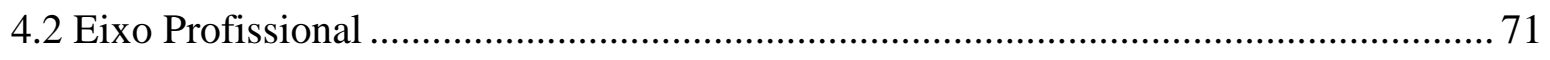

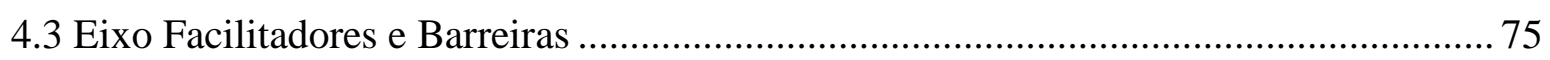

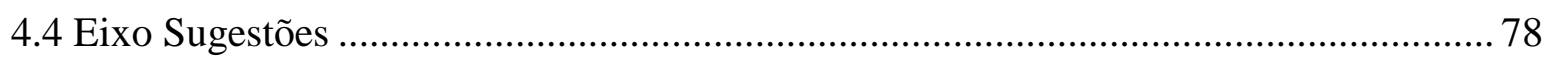

5 Considerações Finais............................................................................................................... 81

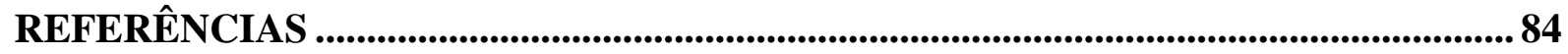

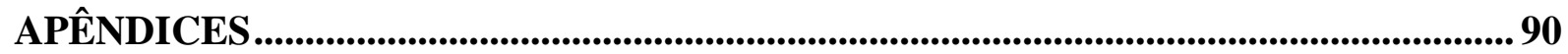

APÊNDICE A - Termo de Consentimento Livre e Esclarecido .......................................... 90

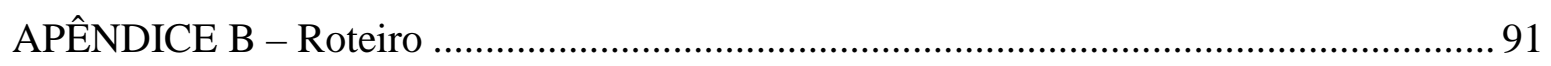




\section{LISTA DE ABREVIATURAS}

\begin{tabular}{|c|c|}
\hline ABNT & Associação Brasileira de Normas Técnicas. \\
\hline CAPES & Coordenação de Aperfeiçoamento de Pessoal de Nível Superior. \\
\hline CAVC & Centro Acadêmico Visconde de Cairu. \\
\hline CCInt & Comissão de Cooperação Internacional. \\
\hline CFC & Conselho Federal de Contabilidade. \\
\hline CID & Classificação Internacional de Doença. \\
\hline DF & Distrito Federal. \\
\hline $\mathrm{EACH}$ & Escola de Artes, Ciências e Humanidades. \\
\hline FAPESP & Fundação de Amparo à Pesquisa do Estado de São Paulo. \\
\hline FCEA & Faculdade de Ciências Econômicas e Administrativas. \\
\hline FEA & Faculdade de Economia, Administração e Contabilidade. \\
\hline FFLCH & Faculdade de Filosofia, Letras e Ciências Humanas. \\
\hline FIA & Fundação Instituto de Administração. \\
\hline FIPE & Fundação Instituto de Pesquisas Econômicas. \\
\hline FIPECAFI & Fundação Instituto de Pesquisas Contábeis, Atuariais e Financeiras. \\
\hline FUVEST & Fundação Universitária para o Vestibular. \\
\hline HU & Hospital Universitário. \\
\hline IBGE & Instituto Brasileiro de Geografia e Estatística. \\
\hline IFES & Instituições Federais de Educação Superior. \\
\hline IME & Instituto de Matemática e Estatística. \\
\hline INCLUIR & Programa de Acessibilidade na Educação Superior. \\
\hline INCLUSP & Programa de Inclusão da Universidade de São Paulo. \\
\hline INEP & Instituto Nacional de Estudos e Pesquisas Educacionais Anísio Teixeira. \\
\hline LDB & Lei de Diretrizes e Bases da Educação Nacional. \\
\hline LIBRAS & Língua Brasileira de Sinais. \\
\hline MEC & Ministério da Educação. \\
\hline ONU & Organização das Nações Unidas. \\
\hline PDF & Portable Document Format. \\
\hline PNE & Plano Nacional de Educação. \\
\hline POLI & Escola Politécnica. \\
\hline PROUNI & Programa Universidade para Todos. \\
\hline SEESP & Secretaria de Educação Especial de São Paulo. \\
\hline SESu & Secretarias de Ensino Superior. \\
\hline SIBI & Sistema Integrado de Bibliotecas. \\
\hline STF & Supremo Tribunal Federal. \\
\hline TGD & Transtornos globais do desenvolvimento. \\
\hline UFSC & Universidade Federal de Santa Catarina. \\
\hline UNESCO & Organização das Nações Unidas para a Educação, a Ciência e a Cultura. \\
\hline UNESP & Universidade Estadual Paulista. \\
\hline UNICAMP & Universidade Estadual de Campinas. \\
\hline USP & Universidade de São Paulo. \\
\hline
\end{tabular}




\section{LISTA DE FIGURAS}

Figura 1. Concentração de obras publicadas sobre o assunto Educação e Deficiência........... 29

Figura 2. Principais autores e quantidade de publicações. .................................................. 30

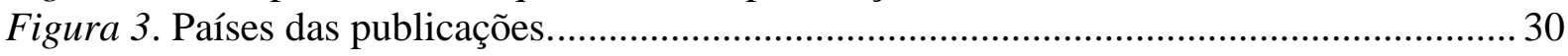

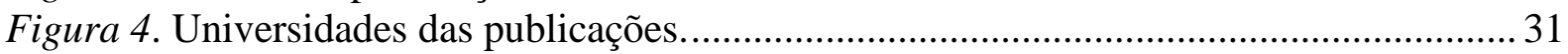

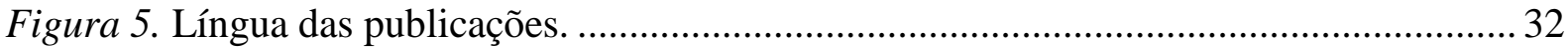

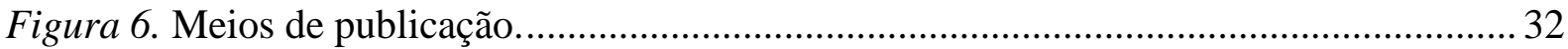

Figura 7. Citações por ano.................................................................................................. 33

Figura 8. Matrículas no ensino médio no Brasil e Estado de São Paulo de 1991 a 2006. Fonte:

Censo da Educação Básica - microdados (INEP, 2010). ..................................................... 47

Figura 9. Proporção entre instituições de educação superior pública e privada de 2000 a 2011

(Censo da Educação Superior/MEC/INEP/DEED, 2011)...................................................... 48

Figura 10. Evolução do número de matrículas na educação superior no Brasil - 1962-2011

(Censo da Educação Superior/MEC/INEP/DEED, 2011)..................................................... 49

Figura 11. Distribuição do número de matrículas por área geral de conhecimento em 2010

(Censo da Educação Superior/MEC/INEP/DEED, 2010).

Figura 12. Distribuição Geográfica de Pessoas com Deficiência na cidade de São Paulo

(Prefeitura de São Paulo, 2012). 


\section{LISTA DE TABELAS}

Tabela 1 Tipos de Deficiência. .18

Tabela 2 Taxa de crescimento anual da população de 1980 a 2007 (IBGE, 2010).................. 40

Tabela 3 Taxa de matrícula bruta no ensino superior de 1999 e 2006 ..................................... 42

Tabela 4 Evolução das taxas de escolarização bruta e líquida na educação superior de 2001 a 2009.

Tabela 5 Alunos matriculados na graduação.

Tabela 6 População total de 15 a 17 anos, matrículas no ensino médio total e relativa á população de 15 a 17 anos e taxas de matrícula no Brasil e no Estado de São Paulo de 1998 a 2006.

Tabela 7 Evolução do Número de Matrículas totais e por série do Ensino Fundamental de 2001 a 2010

Tabela 8 Evolução do Número de Matrículas totais e por série do Ensino Médio de 2001 a 2010

Tabela 9 Evolução do Número de Matrículas, Ingressantes e Concluintes do Ensino Superior de 2001 a 2010

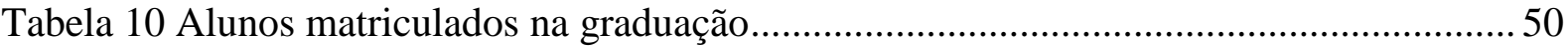

Tabela 11 Resultados de educação para respondentes com deficiência e sem deficiência....... 53 


\section{Introdução}

Segundo números da Organização das Nações Unidas (ONU), havia cerca de 650 milhões de pessoas com deficiência no mundo todo, em 2011. Esse número representa aproximadamente 10\% da população mundial. O último Censo de pessoas com deficiência, realizado em 2010 pela Secretaria dos Direitos da Pessoa com Deficiência do Governo do Estado de São Paulo, mostrou que no Brasil são cerca de 40 milhões de pessoas classificadas com alguma deficiência, seja ela leve, moderada ou grave. Na cidade de São Paulo, em 2012, dados do Censo Inclusão revelavam que 2,7 milhões de pessoas declararam ter alguma deficiência. Nas últimas décadas, o assunto inclusão ganhou visibilidade devido a diversos documentos assinados pelo Governo, tais como a Declaração Universal dos Direitos Humanos, Declaração de Salamanca e a Convenção Internacional sobre os Direitos das Pessoas com Deficiência. A inclusão permeia pela educação. Esta pode ser vista globalmente como estratégia de transformação social, política e econômica, pois por meio dela o cidadão pode adquirir informação e formação necessárias para o trabalho e para a sociedade; segundo Valdes (2006, p. 163) sendo, dessa forma, uma potencial forma de inclusão social.

Esse estudo tem por objetivo geral entender a trajetória dos alunos com deficiência graduados e com alguma passagem pela contabilidade, seja através da faculdade ou através do ambiente profissional. Através da historia oral, foram levantadas as condições encontradas nas instituições que passaram, as intervenções realizadas e o que poderia ser melhorado. Além do objetivo geral, existem outros intermediários, que percorrerão:

$\checkmark$ o histórico das pessoas com deficiência,

$\checkmark$ a legislação existente,

$\checkmark$ uma pesquisa bibliométrica

$\checkmark$ a educação superior e inclusiva utilizando-se de censos escolares.

O problema da pesquisa consistiu em conhecer a experiência de alguns alunos com deficiência e que tenham relação com a contabilidade. “A elaboração do problema inicia um processo de problematização que acompanhará todo o processo da pesquisa, em relação ao qual o pesquisador nunca ficará tranquilo, nem mesmo depois de a pesquisa ter sido concluída.” (Rey, 2010, p. 87). 
O anseio de pesquisar o assunto surgiu do interesse da autora e de seu orientador na primeira semana de ingresso da autora no Programa de Pós Graduação em Controladoria e Contabilidade, onde foram apresentados os professores de cada disciplina e suas linhas de pesquisa. A autora anteriormente desenvolveu um programa de recrutamento de pessoas com deficiência na empresa onde trabalhava e teve muitas dificuldades em conseguir o número mínimo de contratações exigido pela empresa. A partir de então surgiu a inquietação sobre o baixo número de pessoas com deficiência que conseguem um emprego com remuneração alta e uma escolaridade avançada. Ao tomar a decisão de pesquisar sobre o tema, constatou-se que pouco conhecia sobre o assunto, o que tornou esta pesquisa ainda mais desafiadora, fonte de muito aprendizado e estímulo para a superação das dificuldades enfrentadas no seu desenvolvimento. A jornada teve início com a participação da autora em eventos sobre o tema, dentre eles o Encontro Internacional de Tecnologia e Inovação para Pessoas com Deficiência organizado pela secretária do Estado de São Paulo, Linamara Rizzo Battistella e também na matrícula da disciplina Educação Especial, Direito à Educação e Políticas de Inclusão Escolar no Brasil ministrada na Faculdade de Educação da USP pela professora Rosangela Pietro. Vale ressaltar a inexistência de trabalhos na área da Contabilidade, relacionando o ensino de Contabilidade e alunos com deficiência, como será exposto na análise bibliométrica. Mesmo diante das dificuldades encontradas no decorrer deste trabalho, maiores e mais fortes foram as motivações para superá-las, diante da relevância da temática. 


\section{Revisão de Literatura}

\subsection{História das pessoas com deficiência}

As pessoas com deficiência tiveram diversos tratamentos no decorrer da história da humanidade. Segundo Silva (1987, p. 31) “anomalias físicas ou mentais, deformações congênitas, amputações traumáticas, doenças graves e de conseqüências incapacitantes, sejam elas de natureza transitória ou permanente, são tão antigas quanto a própria humanidade”.

Ao realizar uma retrospectiva sobre a situação das pessoas com deficiência junto à sociedade, nota-se inúmeras situações distintas: na Antiguidade existia uma tendência assistencialista e outra marginalizada, segundo Silva (1987). Em Esparta, as crianças que nasciam com alguma deficiência eram eliminadas imediatamente; em Roma, a sociedade permitia aos pais o sacrifício dos filhos com deficiência, que muitas vezes, eram jogados de precipícios ou abandonados na beira de rios, a própria sorte. Em Atenas, influenciado por Aristóteles, pelo sentimento de universalidade, as pessoas com deficiência eram amparadas de forma precária pela sociedade nas instituições de saúde. Além da marginalização e do assistencialismo, nesta época, em Roma, cria-se a utilização comercial das pessoas com deficiência para a nobreza, em tavernas, bordéis e circos; muitas vezes em situações humilhantes (Silva, 1987). O advento da doutrina cristã trouxe junto os princípios de caridade e amor ao próximo, acarretando no surgimento de hospitais voltados ao atendimento, dentre outros, das pessoas com deficiência.

A Idade Média traz a ideia de “castigo de Deus” para as deficiências e neste período, as pessoas com deficiência acabam vivendo à margem da sociedade, organizando-se em grupos, que se revezavam para pedir esmolas. Além disso, com a intensificação de povoamento em regiões concentradas, agravou-se a questão de higiene e saúde da população, favorecendo o surgimento de doenças que acabavam por mutilar membros ou a perda dos sentidos, aumentando o número de deficientes. O Renascimento traz algum avanço neste sentido, ao propor a ciência e o humanismo.

Silva (1987, p. 43) menciona que entre os esquimós mais antigos que mantiveram contatos com missionários franceses nos séculos XVII e XVIII nos territórios canadenses hoje, as pessoas idosas ou deficientes eram deixadas, por sua própria orientação e muitas vezes por 
sua própria escolha e vontade, num local mais propício e próximo dos pontos onde todos sabiam ser a área de convergência contínua e de aparecimento de ursos brancos, para serem por eles devoradas. Segundo acreditavam, os ursos brancos eram considerados como animais sagrados e de grande utilidade para a tribo e que deviam manter-se bem alimentados. Assim, sua pele mantinha-se também em ótimo estado para, quando mortos, bem agasalhem a população.

Além deles, os índios ajores ainda hoje vivem como nômades, em região pantanosa, entre os rios Otuquis e Paraguai, nos isolados confins da Bolívia e Paraguai. São índios orgulhosos de seu estilo de vida. Devido ao nomadismo, todos os recém-nascidos com deficiência, ou mesmo aqueles não desejados, são enterrados vivos, contra sua vontade. Consideram alguns esse tipo de morte altamente desejável, pois a terra os protegerá contra tudo e contra todos.

O século XX mudou a percepção sobre estas pessoas principalmente nos Estados Unidos, onde os "veteranos" de guerra mutilados eram tratados como heróis pela sociedade e a atenção do governo se voltou para este público. (Silva, 1987)

No Brasil, semelhante aos demais países, as pessoas com deficiência eram tratadas à margem da sociedade e em algumas tribos indígenas eram mortas ao nascerem. Após o descobrimento, a deficiência aumentou entre os escravos, consequência das condições precárias de transporte da África, até o continente americano e também dos castigos impostos pelos senhores com amputações de membros, castigos estes previstos em leis da época (Figueira, 2008). O século XIX limitou-se a ação assistencialista do Estado e filantropia da população, de forma precária, onde as pessoas com deficiência, principalmente mental, eram trancafiadas em hospitais e manicômios e retiradas da sociedade.

Do ponto de visto histórico, os direitos conquistados pelas pessoas com deficiência são muito recentes. Pela legislação brasileira, somente a partir de 1969 o tema começa a ser tratado, através do Decreto Lei $n^{0} 1.044$, que dispõe sobre tratamento excepcional para os alunos portadores das afecções que indica. No entanto, é a partir de 1988 que realmente o tema passa a ser recorrente através de Leis, Decretos, Portarias e outros documentos oficiais, como veremos a seguir no próximo tópico. 
2.2 Definição e Legislação sobre pessoas com deficiência

Deficiência, segundo o dicionário Michaelis, é definida como lacuna, falta, imperfeição, insuficiência, mutação cromossômica. O aspecto negativo, trazido no dicionário, reflete a imagem que a pessoa com deficiência tem perante a sociedade.

Atualmente, o termo para designar as pessoas com alguma necessidade especial é "pessoa com deficiência”. Este termo surgiu em 2006 na Convenção sobre os Direitos das Pessoas com Deficiência. Anteriormente o termo utilizado era "portador de deficiência”. Existe controvérsia quanto ao termo adequado a ser utilizado até mesmo entre as pessoas com deficiência. Alguns são favoráveis ao termo atual, outros sugerem o termo "necessidades especiais”. Como mencionado anteriormente, a palavra deficiência traz consigo um significado negativo; “necessidades especiais” torna-se muito abrangente, visto que todo indivíduo pode possuir uma necessidade especial e "portador” traz o sentido de algo que pode ser colocado, retirado, transmitido. A fim de seguir o conceito legislativo, será usado neste trabalho o termo "pessoa com deficiência”, exceto nas citações onde o termo esteja diferente, a fim de que seja preservada a originalidade da citação.

A deficiência é um assunto que permeia diversos ramos do conhecimento, diversas ciências tais como Medicina, Educação, Economia, Direito tratam sobre deficiência; no entanto, a medicina foi pioneira ao tratar o tema:

Entre nós, a medicina vem influenciando as propostas educacionais para os deficientes, não só pelos motivos já expostos, como também por ser, na área do ensino superior, uma das mais antigas no Brasil, junto com o ensino militar, tendo, desde o começo, formado profissionais. As primeiras academias médico-cirúrgicas datam da chegada de João VI ao Brasil, que assim tratou de viabilizar a vida da Corte que com ele veio. A do Rio de Janeiro, Escola Anatômica, Cirúrgica e Médica foi criada em 1809, mais tarde, em 1813, a Academia Médico-Cirúrgica do Rio de Janeiro. (Jannuzzi, 2006, p.32)

O decreto que classifica as deficiências é o Decreto n. ${ }^{0}$ 5.296, de 02 de dezembro de 2004, conforme Tabela 1: 
Tabela 1

Tipos de Deficiência

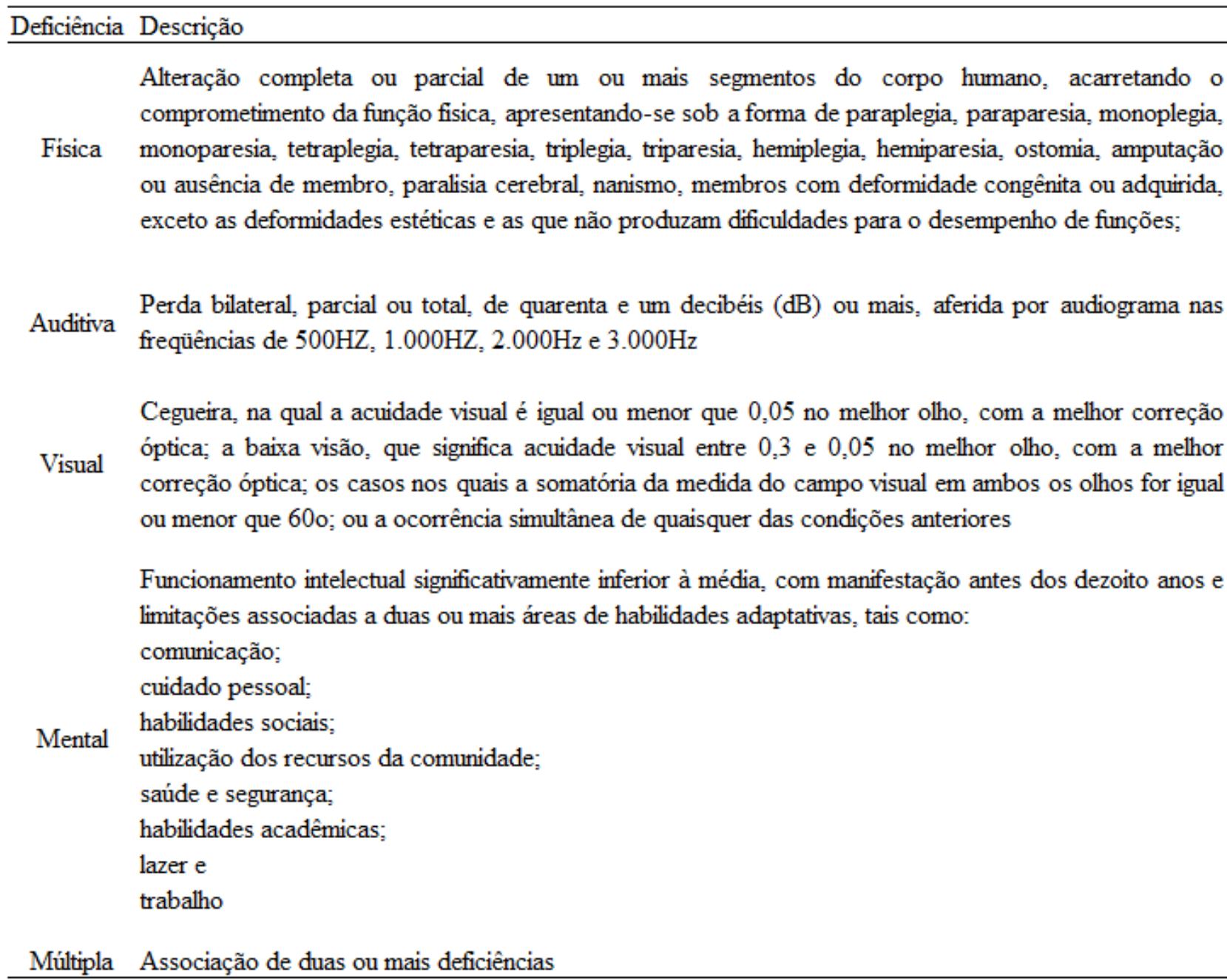

Fonte: Decreto n 5296 de 02 de dezembro de 2004, art $5^{\circ}$

Pela classificação do art. $1^{0}$ da Convenção Internacional sobre os Direitos das Pessoas com Deficiência (2006): "... pessoas com deficiência são aquelas que têm impedimentos de natureza física, intelectual ou sensorial, os quais, em interação com diversas barreiras, podem obstruir sua participação plena e efetiva na sociedade com as demais pessoas".

Os transtornos globais do desenvolvimento (TGD) são distúrbios nas interações sociais recíprocas que costumam manifestar-se nos primeiros cinco anos de vida. Caracterizam-se pelos padrões de comunicação estereotipados e repetitivos, assim como pelo estreitamento nos interesses e nas atividades. Os TGD englobam:

I- $\quad$ Os diferentes transtornos do espectro autista, 


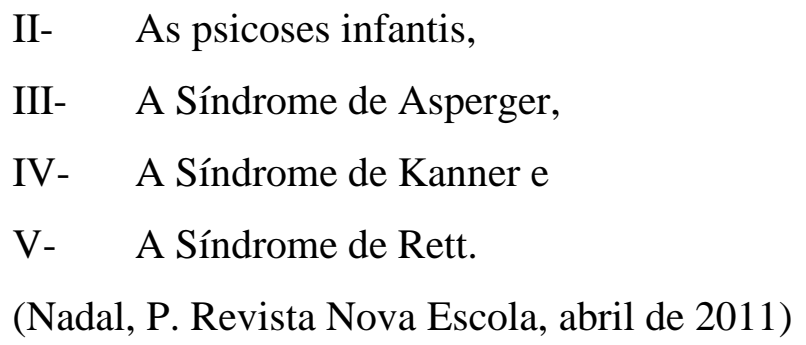

A Política Nacional de Educação Especial (1994) define como pessoas com altas habilidades/superdotados os educandos que apresentarem notável desempenho e elevada potencialidade em qualquer dos seguintes aspectos, isolados ou combinados (Política Nacional de Educação Especial, 1994):

$\begin{array}{ll}\text { I- } & \text { Capacidade intelectual geral; } \\ \text { II- } & \text { Aptidão acadêmica especifica; } \\ \text { III- } & \text { Pensamento criativo ou produtivo; } \\ \text { IV- } & \text { Capacidade de liderança; } \\ \text { V- } & \text { Talento especial para artes e } \\ \text { VI- } & \text { Capacidade psicomotora. }\end{array}$

Do ponto de vista legislativo, serão abordados direitos conquistados a partir de 1988, ano em que a Constituição Federal tratou sobre o tema educação e deficiência. Antes disto, as Constituições anteriores não especificam leis em relação a pessoa com deficiência e a educação. Mencionam somente trechos como educação laica (Constituição, 1891), profissionalização na educação (Constituição, 1937), educação para todos (Constituição, 1967).

O objetivo de elencar os documentos é identificar aspectos legais e normativos sobre o acesso e permanência de alunos com deficiência nas escolas. Os documentos contribuem "para melhor entendimento do caso e também para corroborar evidencias coletadas por outros instrumentos e outras fontes, possibilitando a confiabilidade de achados através de triangulação de dados e de resultados” (Martins, 2012, p. 46).

Na década de 90, paulatinamente, as políticas de inclusão começam a ser implantadas. Temas como acessibilidade, qualidade no ensino e a inclusão dos deficientes no ensino superior começam a ser discutidos de forma organizada. Para isso, são amparados pela legislação através da Constituição Federal de 1988; pela Lei $\mathrm{n}^{0} 7.853$ de 1989, que trata sobre vestibulares; pela Declaração Universal dos Direitos Humanos de 1990; pela Lei de Diretrizes 
e Bases da Educação Nacional nº 9.394 de 1996; pelo Plano Nacional de Educação nº 10.172 de 2001; pela Lei Brasileira de Sinais no 10.436 de 2001; pelo Decreto Federal $n^{\circ} 5.296$ de 2004 sobre Acessibilidade; pela Convenção sobre o direito das pessoas com deficiência de 2006, pela Política Nacional de Educação Especial, na perspectiva da Educação Inclusiva de 2008 e por políticas afirmativas como o Incluir de 2005 e a lei de cotas para estudantes com deficiência em trâmite no congresso.

O marco introdutório na Constituição Federal relacionando deficiência e educação ocorre na Constituição de 1988. O capítulo III trata sobre a Educação, a Cultura e o Desporto. O primeiro artigo deste capítulo, art. 205, menciona a universalidade da educação: “A educação, direito de todos e dever do Estado e da família, será promovida e incentivada com a colaboração da sociedade, visando ao pleno desenvolvimento da pessoa, seu preparo para o exercício da cidadania e sua qualificação para o trabalho" (Constituição da Republica Federativa do Brasil, Brasília, DF, 1988), ou seja, todo cidadão, inclusive as pessoas com deficiência têm direito a educação. O próximo artigo, 206, inciso I menciona a igualdade de condições para o acesso e permanência na escola; ou seja, é papel do Estado prover acesso para as pessoas que assim o necessitem. O artigo 208, no inciso III, mais específico às pessoas com deficiência garante "atendimento educacional especializado aos 'portadores de deficiência', ${ }^{1}$ preferencialmente na rede regular de ensino”. Por fim, o artigo 227, parágrafo 2 menciona que "a lei disporá sobre normas de construção dos logradouros e dos edifícios de uso público e de fabricação de veículos de transporte coletivo, a fim de garantir acesso adequado às pessoas ‘portadoras de deficiência'.” (Constituição da Republica Federativa do Brasil, Brasília, DF, 1988)

Voltada para o acesso da pessoa com deficiência no ensino superior através de concurso vestibular, a Lei $n^{\circ} 7.853$ de 1989, regulamentada pelo Decreto 3298 garante condições necessárias para o deficiente no momento da avaliação: “oferecer adaptação de provas e os apoios necessários, previamente solicitados pelo aluno 'portador de deficiência', inclusive tempo adicional para a realização das provas, conforme as características da deficiência”. A mesma lei, em seu artigo $8^{\circ}$ ameaça com reclusão e multa aquele que "recusar, suspender, procrastinar, cancelar ou fazer cessar, sem justa causa, a inscrição de aluno em estabelecimento de ensino de qualquer curso ou grau, público ou privado, por motivos

\footnotetext{
1 O termo portador de deficiência foi substituído por pessoa com deficiência na Convenção sobre os Direitos das Pessoas com Deficiência em 2006. Porém, será mantido o termo portador nas citações e documentos visando fidelidade aos originais, acompanhados sempre por aspas.
} 
derivados da deficiência que porta”. O Aviso Circular nº 277 de 1996 complementa o tema sobre vestibulares estabelecendo os critérios para a elaboração do edital, o momento da avaliação e a forma de correção: "na elaboração do edital, para que possa expressar, com clareza, os recursos que poderão ser utilizados pelo vestibulando no momento da prova”, "no momento dos exames vestibulares, quando serão providenciadas salas especiais para cada tipo de deficiência e a forma adequada de obtenção de respostas pelo vestibulando" e "no momento da correção das provas, quando será necessário considerar as diferenças específicas inerentes a cada 'portador de deficiência'”, para que o domínio do conhecimento seja aferido por meio de critérios compatíveis com as características especiais desses alunos.

Em nível internacional, em 1990, na Tailândia, todas as nações pertencentes às Nações Unidas aprovaram a nova Declaração Universal dos Direitos Humanos. O artigo 3º parágrafo 5, menciona a universalização da educação e promoção da equidade para as pessoas com deficiência: “As necessidades básicas de aprendizagem das pessoas 'portadoras de deficiências’ requerem atenção especial. É preciso tomar medidas que garantam a igualdade de acesso à educação aos 'portadores de todo e qualquer tipo de deficiência', como parte integrante do sistema educativo".

Em continuidade pelas Nações Unidas, no ano de 1994 foi elaborada a Declaração de Salamanca que trata sobre os princípios da educação especial. O item 40 aborda a questão sobre modelos de sucesso: "Um problema recorrente em sistemas educacionais, mesmo naqueles que provêem excelentes serviços para estudantes 'portadores de deficiências' referese a falta de modelos para tais estudantes.” Alunos de educação especial requerem oportunidades de interagir com adultos com deficiências que tenham obtido sucesso de forma que eles possam ter um padrão para seus próprios estilos de vida e aspirações com base em expectativas realistas. Além disso, alunos com deficiências deveriam ser treinados e providos de exemplos de atribuição de poderes e liderança à deficiência de forma que eles possam auxiliar no modelamento de políticas que irão afetá-los futuramente. Sistemas educacionais deveriam, portanto, basear o recrutamento de professores e outros educadores que podem e deveriam buscar, para a educação de crianças especiais, o envolvimento de indivíduos com deficiências que sejam bem sucedidos e que provenham da mesma região.

Do ponto de vista trabalhista, a Lei 8.213 de 1991 define um percentual de vagas para as pessoas com deficiência. No artigo 93 é estipulado que empresas com mais de 100 funcionários devem garantir um percentual do quadro para as pessoas com deficiência. 
Empresas com até 200 empregados devem cumprir uma cota de 2\%, de 201 a 500 empregados, a cota é 3\%, até 1000 empregados, 4\% e, acima de 1000, 5\%. (Lei 8.213,1991).

A Lei de Diretrizes e Bases da Educação Nacional (LDB) nº 9.394 de 1996 impulsionou uma série de reformas educacionais. Os artigos 58 e 59 merecem destaques visto que estão no capítulo V sobre Educação Especial. O artigo 58 menciona “Entende-se por educação especial, para os efeitos desta Lei, a modalidade de educação escolar, oferecida preferencialmente, na rede regular de ensino, para educandos 'portadores' de necessidades especiais”. O artigo 59 garante “currículos, métodos, técnicas, recursos educativos e organização específicos, para atender às suas necessidades” (Lei de Diretrizes e Bases da Educação Nacional, 1996).

Uma escola "integradora, inclusiva, aberta à diversidade dos alunos” é mencionada no Plano Nacional de Ensino de 2001. Na questão do ensino superior é destacado o tripé nas universidades de ensino, pesquisa e extensão (Plano Nacional de Ensino, 2001). Em suas metas, há o destaque para a importância do assunto junto às universidades no sentido de ensino e pesquisa: "Incluir ou ampliar, especialmente nas universidades públicas, habilitação específica, em níveis de graduação e pós-graduação, para formar pessoal especializado em educação especial, garantindo, em cinco anos, pelo menos um curso desse tipo em cada unidade da Federação” e "Incentivar, durante a década, a realização de estudos e pesquisas, especialmente pelas instituições de ensino superior, sobre as diversas áreas relacionadas aos alunos que apresentam necessidades especiais para a aprendizagem”. O Plano Nacional de Ensino mais recente, de 2014 também menciona o ensino aos alunos com deficiência estabelecendo como estratégias: “ampliar as políticas de inclusão e de assistência estudantil dirigidas aos (às) estudantes de instituições públicas de modo a ampliar as taxas de acesso e permanência na educação superior de estudantes com deficiência, transtornos globais do desenvolvimento e altas habilidades ou superdotação, de forma a apoiar seu sucesso acadêmico" e "institucionalizar programa de composição de acervo digital de referências bibliográficas e audiovisuais para os cursos de graduação, assegurada a acessibilidade às pessoas com deficiência”.

Voltada para as pessoas com deficiência auditiva, a Lei $n^{\circ} 10.436$ de 2002 de Língua Brasileira de Sinais (LIBRAS) é regulamentada pelo Decreto 5.626 de 2005. Segundo Rossetto (2009, p.47), “A Libras é reconhecida como meio legal de comunicação e expressão, em que o sistema linguístico de natureza visual-motora com estrutura própria constitui um 
sistema linguístico de transmissão de acontecimentos, ideias e fatos, provenientes de pessoas surdas.” O decreto obriga a inserção do curso de Libras para a formação de professores para o magistério, em nível médio e superior, e no curso de fonoaudiologia.

Com a finalidade de garantir acessibilidade às pessoas com deficiência física em locais público e privado, a Lei de Acessibilidade do Decreto Federal nº 5.296 de 2004 expõe as diretrizes para uma reforma.

\footnotetext{
"os estabelecimentos de ensino de qualquer nível, etapa ou modalidade, públicos ou privados, proporcionarão condições de acesso e utilização de todos os seus ambientes ou compartimentos para pessoas 'portadoras de deficiência’ ou com mobilidade reduzida, inclusive salas de aula, bibliotecas, auditórios, ginásios e instalações desportivas, laboratórios, áreas de lazer e sanitários.” (Lei de Acessibilidade do Decreto Federal nº 5.296 de 2004, art. $\left.5^{\circ}\right)$.
}

Junto com a Lei da Acessibilidade, a Portaria $n^{0} 3.284$ de 2003 define uma padronização sobre acessibilidade para instruir processos de autorização e reconhecimento de cursos superiores e de credenciamento de instituições. As normas são definidas pela Associação Brasileira de Normas Técnicas (ABNT), através da Norma Brasil 9050, que trata de Acessibilidade de Pessoas "Portadoras de Deficiências” a Edificações, Espaço, Mobiliário e Equipamentos Urbanos:

I - com respeito a alunos "portadores de deficiência” física: - eliminação de barreiras arquitetônicas para circulação do estudante, permitindo acesso aos espaços de uso coletivo; - reserva de vagas em estacionamentos nas proximidades das unidades de serviço;

- construção de rampas com corrimãos ou colocação de elevadores, facilitando a circulação de cadeira de rodas; - adaptação de portas e banheiros com espaço suficiente para permitir o acesso de cadeira de rodas; - colocação de barras de apoio nas paredes dos banheiros; - instalação de lavabos, bebedouros e telefones públicos em altura acessível aos usuários de cadeira de rodas;

II - no que concerne a alunos "portadores de deficiência" visual, compromisso formal da instituição, no caso de vir a ser solicitada e até que o aluno conclua curso: - de manter sala de apoio equipada com máquina de datilografia braile, impressora braile acoplada ao computador, sistema de síntese de voz, gravador e fotocopiadora que amplie textos, software de ampliação de tela, equipamento para ampliação de textos para atendimento a aluno com visão subnormal, lupas, réguas de leitura, scanner acoplado a computador; - de adotar um plano de aquisição gradual de acervo bibliográfico em braile e de fitas sonoras para uso didático; 
III - quanto a alunos “portadores de deficiência” auditiva, compromisso formal da instituição, no caso de vir a ser solicitada e até que o aluno conclua o curso: - de propiciar, sempre que necessário, intérprete de língua de sinais/língua portuguesa, especialmente quando da realização e revisão de provas, complementando a avaliação expressa em texto escrito ou quando este não tenha expressado o real conhecimento do aluno; - de adotar flexibilidade na correção das provas escritas, valorizando o conteúdo semântico; - de estimular o aprendizado da língua portuguesa, principalmente na modalidade escrita, para o uso de vocabulário pertinente às matérias do curso em que o estudante estiver matriculado; - de proporcionar aos professores acesso a literatura e informações sobre a especificidade lingüística do "portador de deficiência” auditiva. (ABNT 9050)

Devido a Portaria, diferentes ferramentas de acessibilidade aos ambientes digitais para pessoas com deficiência foram desenvolvidas. Cada um destes sistemas apresenta características específicas de acordo com as necessidades dos deficientes. Pode-se citar como exemplos o Motrix, o Dosvox e o Virtual Vision². Outras ferramentas também foram desenvolvidas para serem utilizadas indiretamente com estas pessoas, como o Lift, um software de acessibilidade para webdesigners utilizados na construção de websites acessíveis.

Em 2006, a Convenção sobre os Direitos das Pessoas com Deficiência em seu art. 19 menciona:

“Os Estados Partes desta Convenção reconhecem igual direito de todas as pessoas com deficiência de viver na comunidade como as demais e deverão tomar medidas efetivas e apropriadas para facilitar às pessoas com deficiência o pleno desfrute deste direito e sua plena inclusão e participação na comunidade.” (Convenção sobre os Direitos das Pessoas com Deficiência, 2006)

Com relação ao ensino superior na convenção, o artigo 24, item 5 menciona:

“Os Estados Partes assegurarão que as pessoas com deficiência possam ter acesso ao ensino superior em geral, treinamento profissional de acordo com sua vocação, educação para adultos e formação continuada, sem discriminação e em igualdade de condições. Para tanto, os Estados Partes assegurarão a provisão de adaptações razoáveis para pessoas com deficiência.” (Convenção sobre os Direitos das Pessoas com Deficiência, 2006)

De forma abrangente, a Política Nacional de Educação Especial na perspectiva da Educação Inclusiva de 2008 tem como objetivo:

\footnotetext{
${ }^{2}$ Trata-se de softwares especiais com o intuito de facilitar o acesso das pessoas com deficiência á documentos digitais. O Motriz é destinado para pessoas com comprometimento motor severo dos membros superiores. O Dosvox é destinado para pessoas com deficiência visual e reproduz uma voz sintetizada. O Virtual Vision também é voltado para pessoas com deficiência visual e possibilita a utilização do sistema Windows e os aplicativos do pacote Office da Microsoft.
} 


\begin{abstract}
“Assegurar a inclusão escolar de alunos com deficiência, transtornos globais do desenvolvimento e altas habilidades/ superdotação, orientando os sistemas de ensino para garantir: acesso ao ensino regular, com participação, aprendizagem e continuidade nos níveis mais elevados do ensino, transversalidade da modalidade de educação especial desde a educação infantil até a educação superior; oferta do atendimento educacional especializado; formação de professores para o atendimento educacional especializado e demais profissionais da educação para a inclusão; participação da família e da comunidade; acessibilidade arquitetônica, nos transportes, nos mobiliários, nas comunicações e informação; e articulação intersetorial na implementação de políticas públicas.” (Política Nacional de Educação Especial, 2008).
\end{abstract}

“As ações afirmativas são políticas sociais, as quais têm como intuito a inserção de determinados grupos sociais na sociedade, diminuindo as desigualdades. A acessibilidade e a paridade nas condições de vida são os focos das políticas sociais, bem como as ações afirmativas “(Oliveira, 2008, p. 4). Tais políticas têm característica temporária, devendo ser aplicadas em determinados contexto até que haja um efetivo progresso nas condições do grupo. O Governo Federal promove no país estas ações afirmativas focando a inclusão de negros, índios e deficientes nos diversos setores da sociedade. Um exemplo é o Programa de Acessibilidade na Educação Superior (Incluir) vinculado às Secretarias de Ensino Superior (SESu) e Secretaria de Educação Especial de São Paulo (SEESP) do Ministério da Educação (MEC) que desde 2005, oferece recursos financeiros para as universidades, que propõem ações para garantir o acesso pleno de pessoas com deficiência às Instituições Federais de Educação Superior (IFES), tendo, como principais objetivos:

“1.1. Implantar a política de educação especial na perspectiva da educação inclusiva na educação superior; 1.2. Promover ações que garantam o acesso e a permanência de pessoas com deficiência nas

(IFES);

1.3. Fomentar a criação e/ou consolidação de núcleos de acessibilidade nas instituições federais de ensino superior 1.4. Promover a eliminação de barreiras atitudinais, pedagógicas, arquitetônicas de comunicações. Por Núcleos de Acessibilidade, entende-se: espaço físico, com profissional responsável pela organização das ações, articulação entre os diferentes órgãos e departamentos da universidade para a implementação da política de acessibilidade e efetivação das relações de ensino, pesquisa e extensão na área. Os Núcleos deverão atuar na implementação da acessibilidade às pessoas com deficiência em todos os espaços, ambientes, materiais, ações e processos desenvolvidos na instituição. As ações desenvolvidas pelo Núcleo deverão integrar e articular as demais atividades da instituição como os projetos de pesquisa, estudo, intercâmbio, cooperação técnico-científica e 
extensão, demonstrando seu caráter multidisciplinar para a inclusão educacional e social das pessoas com deficiência.” (Edital Incluir, 2008)

Em relação ao sistema de cotas para estudantes com deficiência, existe um Projeto de Lei, ainda em debate no Congresso Nacional. Este projeto prevê a reserva de 10\% das vagas em universidades públicas para estudantes que vivem a condição de deficiência. Contudo, independentemente da aprovação deste projeto, algumas universidades brasileiras já adotam o sistema de cotas para estudantes com deficiência, tomando como parâmetro as Políticas de Ações Afirmativas vigentes. (Santos, 2012, p. 394). Um estudo conduzido por Gois (2009) mostra que no universo de 249 instituições públicas de ensino superior, 19 destas já desenvolviam algum tipo de ação afirmativa em benefício dos referidos estudantes. Dentre as instituições que já adotavam o sistema de cotas para estudantes com deficiência no Brasil, destacavam-se as universidades estaduais do Rio de Janeiro, de Goiás, do Rio Grande do Sul e as universidades federais do Maranhão, Paraná e Sergipe. Cabe ressaltar que o percentual de estudantes cotistas com deficiência não alcança 1\% do total das matrículas destas instituições, apesar de elas terem implantado este sistema há pelo menos três anos. Essa situação é evidente até mesmo na Universidade Estadual do Rio Grande do Sul, pioneira na reserva de vagas para estudantes com deficiência e que já adota a reserva de $10 \%$, conforme sugere o Projeto de Lei em tramitê no Congresso Nacional.

Um elevado número de documentos da Legislação voltados para a pessoa com deficiência foram consultados, porém referente ao ensino de forma geral e ensino superior foram selecionados os citados acima. Pouco se fala na Legislação sobre ensino superior, principalmente pelo baixo número de alunos com deficiência matriculados em faculdades e também pelo Governo atualmente não garantir nem o Ensino Básico para esta população. Pelo exposto, percebe-se grandes mudanças ocorridas na Legislação em benefício das pessoas com deficiência a partir da década de 90. Esses avanços contaram com a participação das pessoas com deficiência, principais interessadas nestas mudanças e também de familiares, principalmente pais; como evidencia Mazzotta (2005, p. 64): "Historicamente, os pais têm sido uma importante força para as mudanças no atendimento aos 'portadores de deficiência'. Os grupos de pressão por eles organizados têm seu poder político concretizado na obtenção de serviços e recursos especiais para grupos de deficientes" No entanto, poucas pessoas com deficiência conhecem ou desfrutam de todos estes direitos; muitos pela vergonha que sentem ao assumir sua deficiência e outros pelo desconhecimento da gama de direitos que foram conquistados nas últimas décadas. 
A transformação dessas políticas em ações efetivas requer disposição para um reposicionamento da sociedade como um todo, incluindo as pessoas com deficiência e no limite, a adoção de novos paradigmas.

Além da legislação vista neste capítulo, pretende-se trazer no próximo tópico o que a literatura produziu sobre o tema deficiência e educação em termos quantitativos.

\subsection{Pesquisa Bibliométrica}

Neste capítulo pretende-se analisar quantitativamente obras publicadas mundialmente relacionadas simultaneamente à educação superior e a deficiência utilizando a análise bibliométrica. A bibliometria, segundo Araújo (2006, p.12): “é a técnica quantitativa e estatística de medição dos índices de produção e disseminação do conhecimento científico”.

Para atingir este objetivo, foi utilizado o programa de análise de dados do Web of Knowledge, conjunto de base de dados compilados onde é possível identificar o impacto das publicações periódicas sobre determinado assunto desde 1900, junto com o banco de teses da Coordenação de Aperfeiçoamento de Pessoal de Nível Superior (CAPES). A CAPES ligada ao MEC mantém uma das maiores bibliotecas virtuais do mundo: o Portal de Periódicos da CAPES. Este portal oferece acesso a mais de 24 mil títulos com trabalhos abrangendo todas as áreas do conhecimento, disponibilizados em versão integral. Há ainda 130 bases referenciais, com informações bibliográficas; 150 mil livros digitais, nove bases de patentes, além de estatísticas, normas técnicas, e um banco de teses e dissertações. Entre os bancos de teses destaca-se o Banco de Teses da CAPES, criado em março de 2001, é uma ferramenta de busca e consulta, relativa a teses e dissertações defendidas no Brasil desde 1987. As informações são fornecidas diretamente à CAPES pelos programas de pós-graduação, que se responsabilizam pela veracidade dos dados. A base permite a pesquisa por autor, título e palavra-chave (Moreira \& Stroparo, 2013). Considerou-se como objeto de estudo as dissertações de mestrado e teses de doutorado em Educação Inclusiva no Ensino Superior, e a consulta ocorreu no Banco de Teses da Capes, adotando-se a metodologia da análise bibliométrica.

A partir de combinações de palavras chaves tais como deficiência, portador de necessidades especiais, inclusão social, acessibilidade, educação, educação especial, políticas inclusivas, ensino superior, contabilidade encontrou-se no site grande quantidade de artigos relacionados 
(cerca de 780 trabalhos). Após o filtro por área de pesquisa (Educação, Negócios, Administração, Economia, Pedagogia e Sociologia) a quantidade de artigos foi reduzida para 337. Por fim, uma triagem manual feita pela autora separou artigos pertinentes ao tema, restando 137 publicações. Destes, foram lidos 25 dos quais 9 contribuíram na composição deste trabalho, tais como Martins (2012), Castilho (2012), Moreira (2005, 2008, 2013), Rossetto (2009), Ferrari e Sekkel (2007), Miranda e Galvão Filho (2012), Sassaki (1997).

Buscou-se também dentre as palavras chaves o termo "ensino de contabilidade e pessoa com deficiência”, porém não foi encontrado nenhum trabalho com essa temática, somente artigos relacionados à profissão de contador e a deficiência, como exemplo os artigos dos escoceses Duff e Ferguson (2007, 2011), dos ingleses Bishop e Boden (2008) e dos ingleses Roulstone e Williams (2013). A respeito destes artigos, mais adiante haverá um tópico descrevendo o conteúdo.

Nesta seção, serão apresentados e discutidos os dados obtidos da análise destas 137 publicações destas áreas. Inicia-se por um histograma das obras encontradas no decorrer dos últimos vinte anos, na sequência são mostrados os principais autores que escreveram sobre o tema, os países em que foram publicados, as universidades que os elaboraram, a língua em que foram escritos, os tipos de publicação, se artigos, livros, anais divulgados em congressos... Por fim, o número de vezes que as principais publicações foram citadas por ano.

Ao analisar a quantidade de publicações por ano relacionadas ao tema Deficiência e Educação, foram encontrados nos últimos vinte anos, 85 publicações representadas abaixo na Figura 1. A diferença de 52 publicações, para o total de 137 que serão analisadas no presente trabalho, estão dispersas entre os anos de 1922 até 1993. A representação abaixo não apresenta linearidade dos dados obtidos; em 1995, por exemplo, constatam-se 5 publicações e no ano seguinte nenhuma. Além disto, no ano de 2002 não foi encontrado nenhum trabalho sobre o assunto. De 2009 até 2013, constata-se um aumento na produção, atingindo a média de sete obras publicadas por ano, um valor bem superior do que a média de 1993 a 2008 de 3 publicações ao ano. 


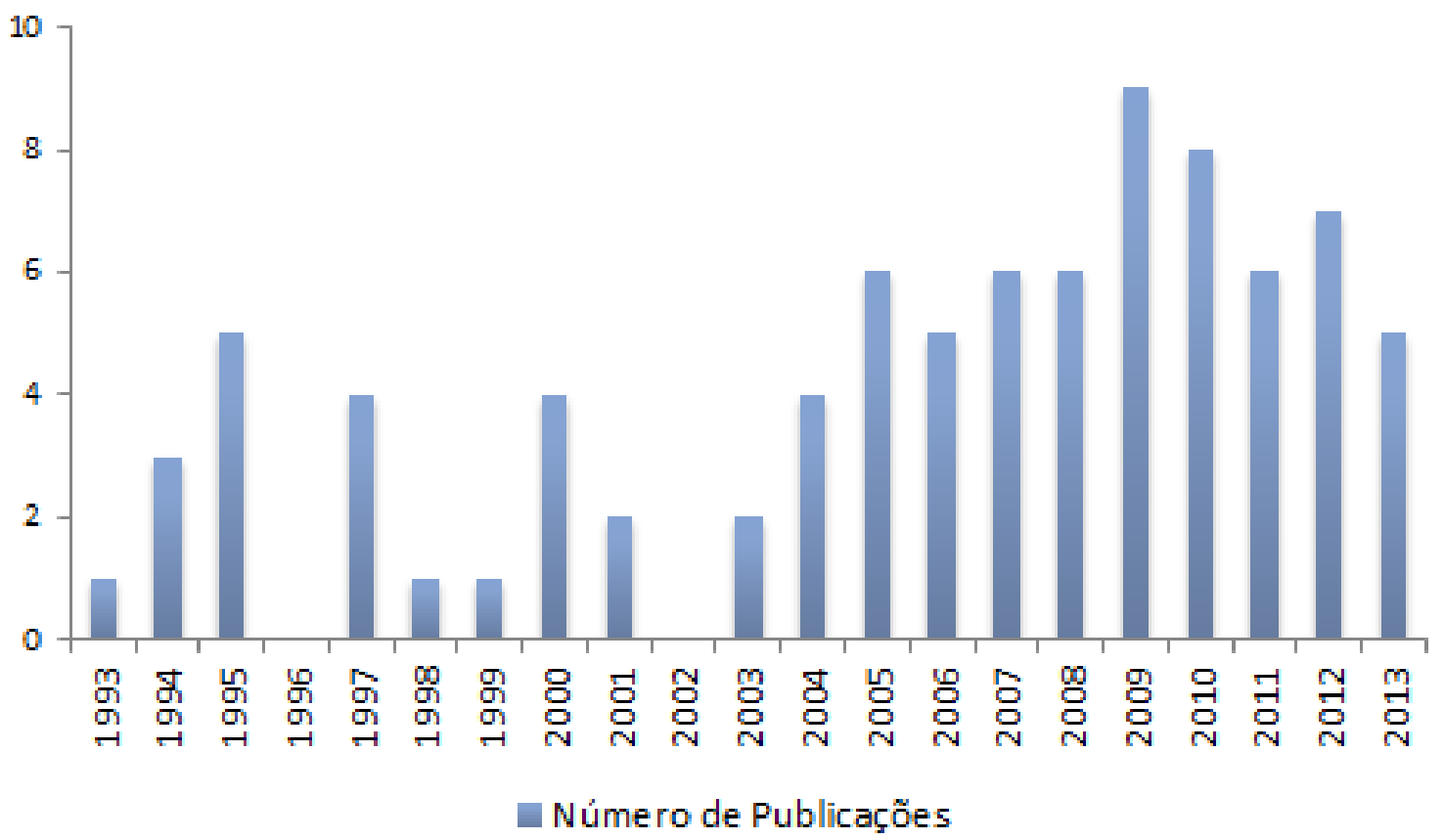

Figura 1. Concentração de obras publicadas sobre o assunto Educação e Deficiência.

As universidades brasileiras vêm produzindo trabalhos científicos sobre educação inclusiva de alunos com deficiência, abrangendo os seguintes eixos de análise: formação de professores, políticas inclusivas, ingresso e permanência na universidade. Registra-se que a produção cientifica em termos de Educação Inclusiva no Ensino Superior em teses e dissertações está sendo difundida timidamente visto que o interesse pelo tema é recente. (Moreira \& Stroparo, 2013).

O próximo item de análise consiste em evidenciar os principais autores que escreveram sobre o tema. A Figura 2 mostra os dez principais autores encontrados. Uma lei conhecida na bibliometria é a Lei de Lotka, que trata sobre a produtividade dos autores. Esta lei estabelece que grande parte do que é escrito sobre um tema está concentrado em poucos autores. De acordo com a Lei de Lotka, a pesquisa abaixo encontrou 28 artigos escritos por 10 autores, destaque para Moreira, com 8 publicações. As demais 114 publicações foram escritas por somente um autor. 


\begin{tabular}{|lccrr|}
\hline Autor & Artigos & \% Artigos Autor & Artigos & \multicolumn{2}{c|}{ \% Artigos } \\
\hline Moreira, Laura C. & 8 & $5,84 \%$ Richardso & 2 & $1,46 \%$ \\
Konur O. & 3 & $2,19 \%$ Riddell S. & 2 & $1,46 \%$ \\
Tinklin T. & 3 & $2,19 \%$ Smith A. & 2 & $1,46 \%$ \\
Beckett A. E. & 2 & $1,46 \%$ Taylor M. & 2 & $1,46 \%$ \\
Haycock D. & 2 & $1,46 \%$ Thompsor & 2 & $1,46 \%$ \\
\hline
\end{tabular}

Figura 2. Principais autores e quantidade de publicações.

Com a finalidade de entender onde mais se escreve sobre o tema, serão apresentados dados dos principais países onde ocorreram as publicações, as universidades e a língua original dos trabalhos.

Na Figura 3 é possível identificar que o maior país em termos de publicações a respeito do tema é os Estados Unidos com 45 artigos (33\% do total). Na sequência, o Brasil surge com 26 artigos, a Inglaterra com 25, Canadá com 6, Escócia com 4, Turquia com 3 e Finlândia com 2. O número de publicações em outros países atinge 26; sendo que cada país possui 1 artigo publicado.

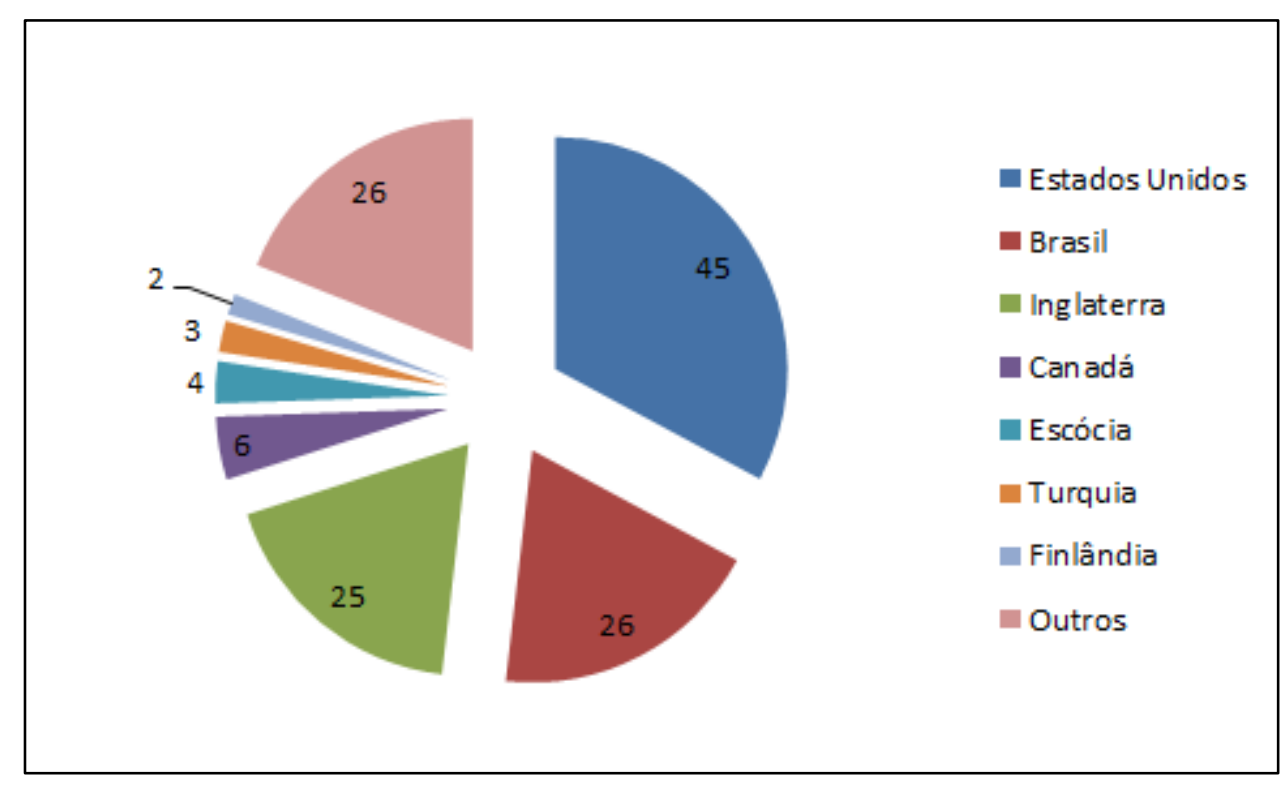

Figura 3. Países das publicações.

A Figura 4 traz as universidades que mais publicaram os artigos. Um fato a ser destacado abaixo é que das universidades que mais publicaram o assunto, cinco delas estão no Reino Unido (University Edinburgh, University Leeds, University Strathclyde, Hereward Coll e University Chester). No gráfico anterior, 33\% das publicações foram produzidas nos Estados 
Unidos; portanto, esperava-se encontrar um número maior de universidades americanas, fato não constatado. Os Estados Unidos aparecem em segundo lugar, com quatro universidades em destaque no assunto. Isso deixa claro que apesar de possuir mais trabalhos sobre o assunto, as produções nos Estados Unidos são mais dispersas do que no Reino Unido.

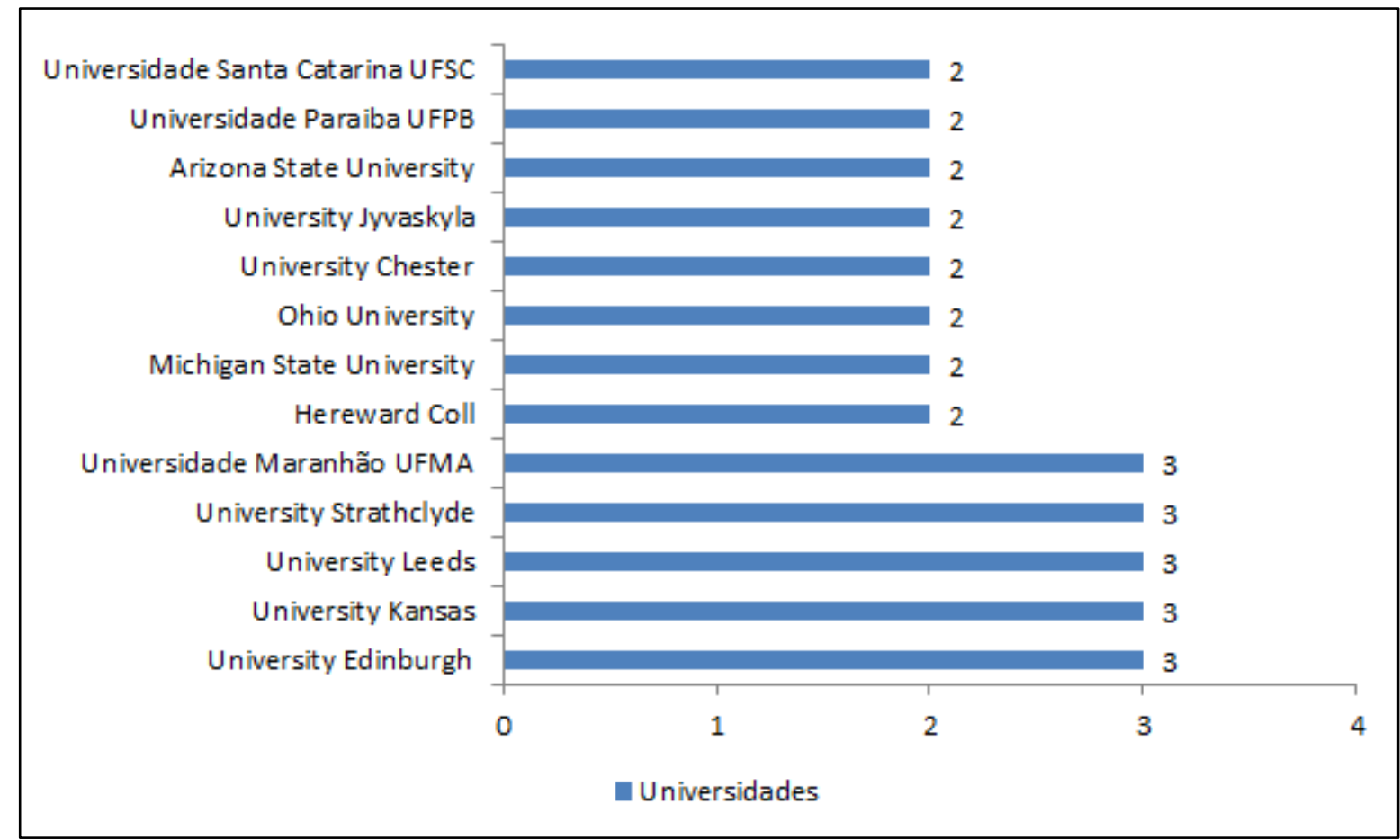

Figura 4. Universidades das publicações.

Por fim, é possível deduzir de acordo com os dois últimos gráficos, que a língua dos trabalhos publicados em sua maioria é o inglês com 74\% das publicações, 102 trabalhos, seguido pelo português com 19\%, 26 trabalhos, conforme Figura 5. Com isso, inferimos que os trabalhos dos outros países foram traduzidos para o inglês em sua publicação. 


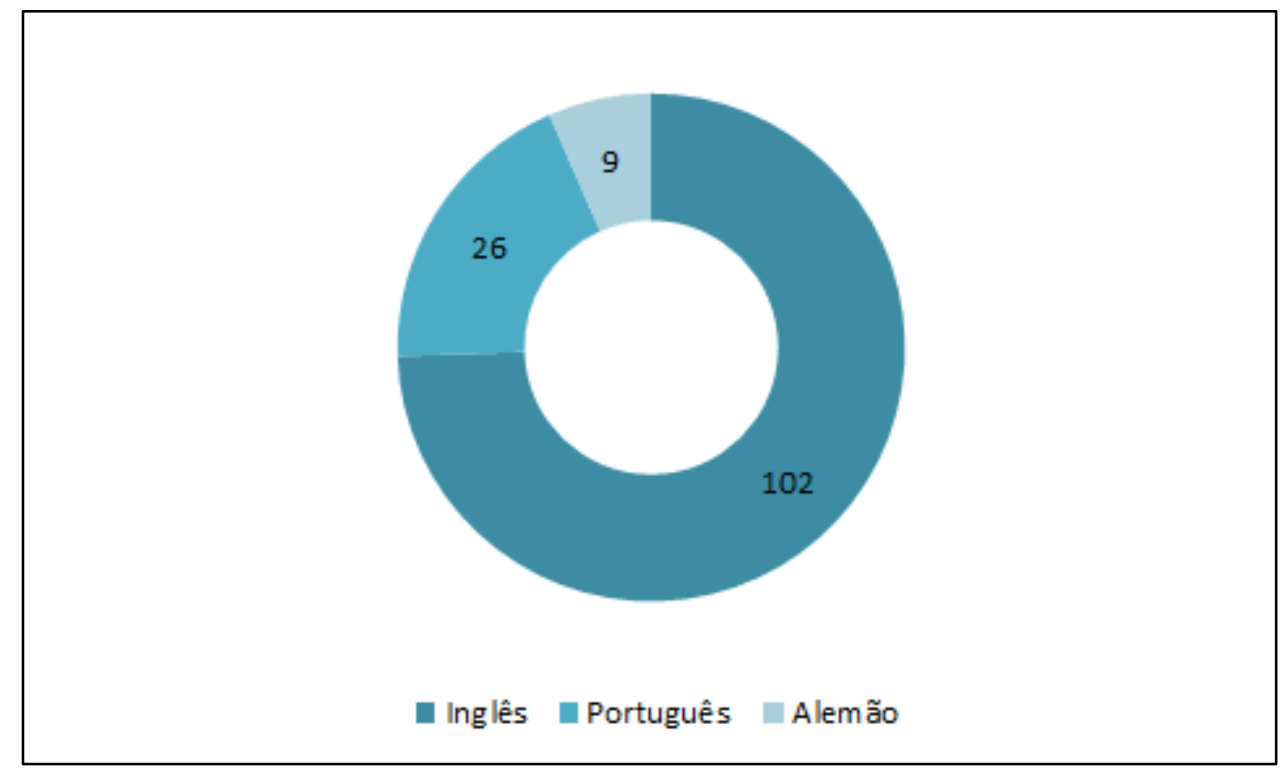

Figura 5. Língua das publicações.

Outra comparação que pode ser feita diz respeito aos tipos de publicações. Pode-se observar no Figura 6 que a grande concentração dos trabalhos está nos artigos, representando 74\% do total com 102 trabalhos. Na sequência, aparecem os livros com 15\% de representatividade (20 livros), os periódicos e revistas com $4 \%$ cada um e os anais divulgados em congressos com $3 \%$.

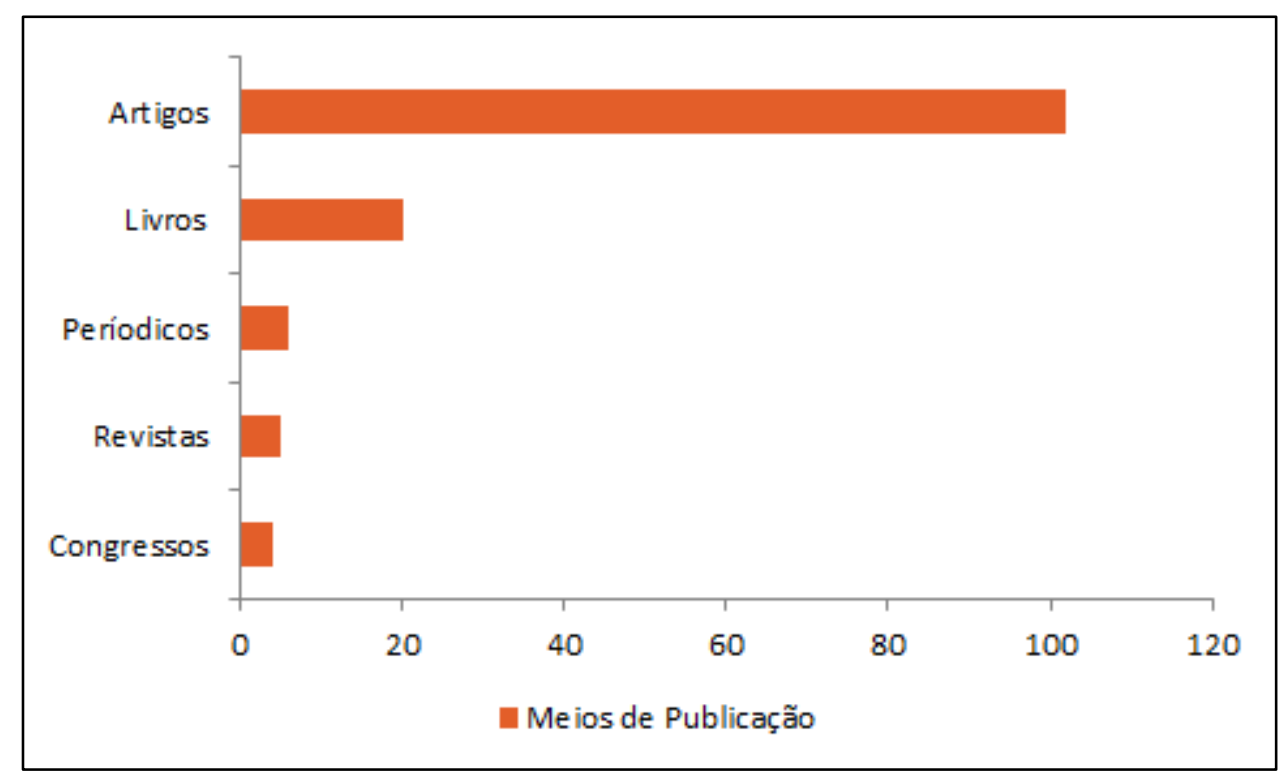

Figura 6. Meios de publicação. 
As citações são um indicativo de representatividade de determinada obra. Sendo assim, muitos trabalhos recebem diversas citações e por isso, obtém grande importância. Por meio desse estudo, foi possível levantar anualmente quantas vezes estas obras foram citadas em outros trabalhos. Analisando um período de vinte anos, chegamos a 362 citações; representando uma média de 17,2 citações por ano. Se considerarmos que o volume analisado foi de 137 trabalhos, em vinte e um anos chegamos a 2,6 citações por trabalho, um volume muito baixo quando comparado com a literatura de outras obras. O gráfico 6 nos mostra a frequência dessas citações anualmente. De forma análoga aos autores por ano, as citações também ganham um incremento de 2009 a 2013, apresentando 41 citações por ano. No período anterior de 1993 a 2008, a média permaneceu em 10 citações.

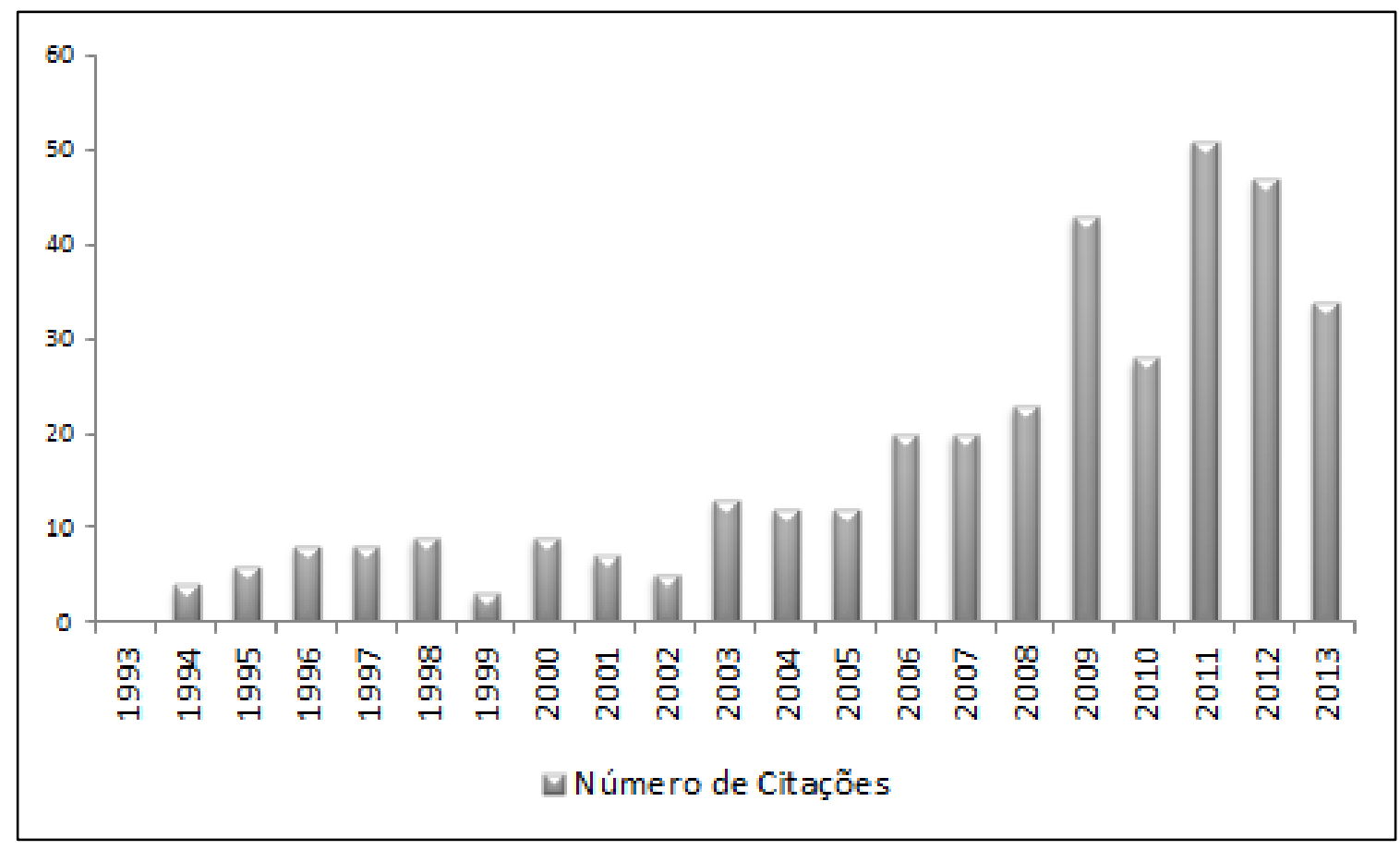

Figura 7. Citações por ano.

A pesquisa bibliométrica nos mostra que há trabalhos mencionando o assunto; no entanto, ainda percebemos ações incipientes. Como constatado nos trabalhos, o assunto vêm ganhando importância na literatura a partir de 2008 com incremento de trabalhos e citações no meio acadêmico. “A capacidade de pressão dos grupos organizados por 'portadores de deficiência' tem sido evidenciada na própria elaboração da legislação sobre os vários aspectos da vida social.” (Mazzotta, 2005, p. 65). 
A pesquisa bibliométrica foi importante neste trabalho para delimitar a produção científica sobre o tema e a partir daí, extrair contribuições nesta dissertação. Autores como Martins (2012), Castilho (2012), Moreira (2005, 2008, 2013), Rossetto (2009), Ferrari e Sekkel (2007), Miranda e Galvão Filho (2012), Sassaki (1997); identificados nesta análise bibliométrica, contribuíram na composição deste trabalho em trechos sobre inclusão, cotas, legislação.

Na tentativa de encontrar trabalhos acadêmicos com os temas de contabilidade e pessoas com deficiência, foram localizados cinco artigos relacionando a profissão de contabilidade e as pessoas com deficiência. Como o tema central desta dissertação trata sobre o ensino superior e as pessoas com deficiência, foram feitas diversas pesquisas com a finalidade de localizar trabalhos mencionando os dois assuntos, porém, infelizmente não foi possível identificar trabalhos que tratassem de ambos assuntos. No próximo capítulo serão apresentadas as principais ideias trazidas pelos trabalhos relacionando contabilidade e pessoas com deficiência.

\subsection{Contabilidade e Pessoas com Deficiência}

O surgimento do capitalismo reforçou a ideia da eficiência do trabalho braçal, onde a economia industrial prevaleceu e exigiu uma alta produtividade dos trabalhadores. As pessoas com deficiência, diante desse cenário, eram muitas vezes consideradas inadequadas para alguns trabalhos e, portanto, geravam menos valor para a sociedade capitalista. Historicamente, é claro que, seguindo o advento do capitalismo, o imperativo trabalho criou um regime de classificação de corpos capazes e não capazes. O discurso médico sobre deficiência apoiado e sustentado pelo capitalismo permite legitimamente rejeitar corpos considerados inadequados por sua capacidade produtiva. Este modelo, surgido no Reino Unido, classifica a deficiência como uma tragédia pessoal, como algo errado na pessoa. Uma vez identificada a deficiência, a visão é patológica e o sujeito submetido a diversos tratamentos para a cura ou para tentar minimizar as consequências da deficiência. Efetivamente, o modelo médico impede as pessoas com deficiência de contestar seu status inferior, tornando-o não contestável. 
Em contraste, há outra visão para a deficiência, denominada modelo social, no qual a preocupação recai nas barreiras atitudinais e psicológicas que a pessoa com deficiência enfrenta em seu cotidiano.

Dentro deste contexto, a contabilidade desempenhou seu papel ao medir a produtividade, principalmente através da contabilidade de custos. Seria importante refletir se, indiretamente, a contabilidade não acentuou ainda mais o preconceito com as pessoas com deficiência ao tentar quantificar pessoas versus trabalho.

Na profissão contábil, estudos feitos por Duff e Ferguson (2007), demonstram que as empresas de auditoria contábil recorrem a contratação de funcionários com deficiência quando há uma escassez de funcionários sem deficiência, funcionando como um "exército de trabalho reserva” e que o emprego em contabilidade é marcado pela ausência de funcionários com deficiência devido aos fatos abaixo:

$\checkmark \quad$ Falta de qualificação necessária em contabilidade para exercício da profissão (onde muitas pessoas com deficiência não alcançam um título de graduação);

$\checkmark \quad$ Falta de disponibilidade em viagens e longas horas fora de casa;

$\checkmark \quad$ Questão da imagem e aparência do profissional de contabilidade;

$\checkmark \quad$ Dificuldade no acesso aos clientes, onde nem sempre há estrutura adequada para certas necessidades, tais como rampas de acesso para deficientes físicos, leitor para deficientes visuais, intérpretes para deficientes auditivos.

De todos os motivos acima, nenhum é atribuído como responsabilidade das empresas de contabilidade; são sempre relacionados a fatores externos da empresa, tais como a falta de qualificação, a disponibilidade, a aparência; o acesso ao cliente. Estes fatores tendem a legitimar a falta de profissionais em contabilidade com deficiência nas empresas. Em muitos casos, as oportunidades não são oferecidas aos funcionários com deficiência a fim de demonstrarem seus talentos e habilidades, com receio da incapacidade para executar determinada atividade. Ao invés, mitos e estereótipos em relação a performance da pessoa com deficiência prevalecem, impedindo a empregabilidade ou promoção das pessoas com deficiência.

Duff, Ferguson e Gilmore (2007) relatam em outro trabalho o conhecimento dos gerentes de recursos humanos em relação aos funcionários com deficiência. É demonstrado no trabalho 
que a maioria dos gerentes de recursos humanos só têm conhecimento das características legais de empregar pessoas com deficiência nas empresas.

Acerca da questão levantada pela falta de qualificação necessária para a profissão contábil, no trabalho de Duff e Ferguson (2007); dados ingleses constatavam 6\% da população de graduandos com alguma deficiência em 2004, cerca de 38000 alunos; número este que dobrou em relação a 2000. No entanto, alguns pesquisadores estimam que este número possa ser maior devido ao fato de muitos alunos não se auto declararem deficientes. Há autores que estimam 10\% dos graduandos com alguma deficiência, segundo o próprio artigo de Duff e Ferguson (2007).

Encorajar os funcionários das empresas contábeis a se auto declararem como deficientes traria um melhor entendimento do tamanho da população de contadores com alguma deficiência. Uma vez estabelecida esta população, seria possível criar uma rede de trabalhadores contábeis com deficiência objetivando a troca de experiências, identificação de melhores práticas e estimular a diversidade na profissão, tornando mais aceitável socialmente a questão da deficiência e mais atrativa para as pessoas com deficiência.

Os achados dos artigos consultados apontam que a deficiência raramente impacta na capacidade do individuo em realizar seu trabalho contábil, porém as barreiras sociais e intelectuais, principalmente dos empregadores e gerentes impedem a expansão das pessoas com deficiência no setor contábil.

\subsection{Educação Especial em Outros Países}

Neste tópico serão abordados trabalhos referentes à França, Inglaterra e Alemanha e outros países no que diz respeito ao tratamento do ensino oferecido às pessoas com deficiência.

Na França, a preocupação com esta parcela da população começou a partir do século XVII junto às crianças deficientes, por meio do assistencialismo, fruto da caridade cristã, da filantropia e de alguns homens letrados. Mas somente na década de 70 do século XX, ocorreu a institucionalização da “deficiência” por meio de textos legislativos, aparecimento de associações que tratam da causa e do orçamento público posto a disposição das questões relacionadas à deficiência. O Direito foi o meio de sair das práticas filantrópicas adotadas anteriormente à década de 70, visto que o direito pode ser reivindicado por ser uma garantia 
dada ao cidadão, um passo fundamental na constituição da cidadania de uma pessoa com deficiência. A lei que trouxe esse direito foi promulgada em 1975, a "Loi 75-534" denominada a "Loi d'orientation em faveur des personnes handicapes" que trouxe ao estado a responsabilidade dos direitos gerais, e consequentemente da educação das pessoas com deficiência (Mendes, 2010).

Beyer (2004) traz em seu estudo, o exemplo da Alemanha, da escola Flämming, ou conhecida também como modelo Flämming, tida como a primeira e mais importante experiência na concepção de integração de alunos com e sem deficiência, neste país. Criada por iniciativa dos pais na década de 70, mas em conjunto com professores, equipe diretiva e equipe científica da universidade que acompanhava o projeto. O princípio que norteava a escola era se as condições pedagógicas seriam apropriadas e suficientes para receber os alunos em seus ritmos de aprendizagem, e não se a criança com deficiência poderia participar ou não da escola, o objetivo era incluir o aluno. O processo da escola Flämming parte do princípio de que a escola e a prática do professor devem ser transformadas, não para o modelo tradicional onde o aluno se adapta ao modelo do professor, mas ao inverso, onde o professor se adapta às necessidades do aluno. O ensino no modelo dessa escola é baseado na inclusão, orientado ao aluno, fazendo com que as práticas pedagógicas e a estrutura escolar sejam voltadas às necessidades dos alunos e fortemente baseadas em princípios, de forma a se adaptarem e responderem melhor às condições de ensino (Beyer, 2004).

A pesquisa de Laplane (2006) sobre políticas de educação inclusiva na Inglaterra, mostra que a década de 70 foi também para este país um marco no que diz respeito a este tema, quando foi elaborado o Relatório de Warnock, produto do trabalho de um comitê governamental, com o objetivo de investigar e recomendar ações relacionadas à provisão de educação especial no país. Este relatório foi responsável por trocar a responsabilidade de ensinar, antes das instituições de ensino específicas para alunos especiais, para as autoridades escolares e professores do ensino regular, transformando a visão de que o ensino especial seria "separado e alternativo”, mas deveria ser “adicional e suplementar”. Muitas das recomendações contidas no referido relatório vieram, posteriormente, a fazer parte de uma sucessão de textos oficiais do governo. Os últimos documentos oficiais acerca do assunto destacam que os alunos com necessidades especiais devem ser atendidos em escolas comuns. A partir de então, foi elaborado o plano Early Years Action. Este plano consiste em uma série de intervenções junto à criança com deficiência através de programas personalizados, dispondo de tempo adicional do adulto, materiais distintos para aprendizagem, equipamentos especiais e apoio individual; 
tudo para aumentar o progresso da aprendizagem do aluno. Ao final é gerado um relatório por estudante propondo metas a serem atingidas no curto prazo e a cada quatro meses esse relatório é revisado por diversos especialistas. (Hegart, 2008).

Após análise de outros países, ditos desenvolvidos, é possível perceber que os direitos assegurados às pessoas com deficiência ainda são muito recentes, quando comparados a história e há muito a ser feito. "Entretanto, mesmo em países desenvolvidos onde, os benefícios sociais conquistados têm sido mais numerosos, estes têm sido no presente considerados insuficientes, quando enquadrados nos orçamentos internacionais, nas economias, nas incertezas da universalidade dos direitos, obrigações das nações.” (Mendes, 2010, p.13).

No próximo capítulo serão apresentados dados sobre o ensino superior no Brasil, a fim de contextualizar o momento que o país apresenta.

\subsection{Educação Superior}

O ensino superior no Brasil foi marcado pela exclusão até décadas atrás. Passados 300 anos de existência do país, devido a colonização e a resistência de Portugal, não existia nenhuma instituição de ensino superior. Somente a elite tinha acesso às universidades, fora do país, geralmente na Europa. Várias tentativas por parte dos jesuítas surgiram neste período para criação de universidades, no entanto, somente com a chegada da família real portuguesa em 1808 que se iniciou o ensino superior no país.

Oliven (1992, p.65) afirma que: “a criação das primeiras universidades brasileiras conservava o caráter elitista e, ao mesmo tempo, meramente profissionalizante dos cursos. Mantinha-se alheia às necessidades da maior parte da população e não incentivava o desenvolvimento da ciência e da tecnologia”.

Diante deste contexto excludente do ensino superior, levou-se muito tempo até que o assunto pessoas com deficiência no ensino superior fosse discutido e tangibilizado. O próprio histórico mostra a exclusão total da sociedade que as pessoas com deficiência enfrentaram. Cogitar estudar um curso superior realmente era algo raro há cinquenta anos, somente uma minoria de pessoas com deficiência abastada financeiramente alcançavam esse grau.

Contudo, é preciso não perder de vista que o nascimento da universidade no Brasil não se concretizou alicerçado às necessidades da realidade educacional nacional bem como, não se 
pautou em políticas governamentais construídas a partir da preocupação de a mesma contribuir significativamente para democratizar o direito à educação. Mesmo com a concretização em 1931, do Estatuto das Universidades Brasileiras, considerado como um dos grandes marcos estruturais da universidade em nosso país, pouco se alterou do caráter excludente e seletivo que vinha caracterizando o Ensino Superior.

Entretanto, hoje é numa visão totalizante de ser humano, numa concepção alargada e ampliada que vai além da participação política que precisamos conceber a educação, principalmente quando se deseja incluir e rever o quadro histórico instituído de exclusões. Do mesmo modo que, não se pode perder de vista que, fazendo parte do cenário de exclusões, de toda ordem, estão as pessoas com necessidades educacionais especiais que, foram e ainda são representados, pelas categorias da ineficiência, do desvio, do atípico e do improdutivo (Moreira, 2005).

Fatos evidenciam que a educação pode transformar a vida de uma pessoa, principalmente uma pessoa com deficiência, nos últimos anos o conceito de inclusão também vem abordando a inclusão no ensino superior. “O objetivo da educação para alunos 'portadores de deficiência' é o de reduzir os obstáculos que impedem o indivíduo de desempenhar atividades e participar plenamente na sociedade” (Nogueira, 2003, p.148).

O artigo 205 da Constituição fala sobre a universalização da educação. O Brasil avançou rumo a universalidade em meados da década de 90, através do Ensino Fundamental: “atingiram-se taxas de escolarização superiores a 95\% no país como um todo e em suas regiões, resultado fortemente impulsionado por políticas governamentais visando à incorporação de toda a população em idade escolar nesse nível de ensino” segundo relatório da Fundação de Amparo à Pesquisa do Estado de São Paulo (FAPESP) em 2010. A permanência na escola foi foco de ações por parte dos sistemas públicos de Educação Básica. Muitos deles, estaduais e municipais, estabeleceram medidas e programas visando à redução das disparidades entre idade dos alunos e série cursada, quebrando as práticas de elevados percentuais de reprovação. Entre tais programas estão os de aceleração da aprendizagem e os de implantação de ciclos no Ensino Fundamental, sempre na busca de melhoria/garantia de eficiência do processo de aprendizagem (LDB, 1996, Cap. II, art.23․). A seriação anual foi substituída pelos ciclos de aprendizagem, especialmente no Ensino Fundamental. A premissa utilizada foi oferecer aos alunos um período mais prolongado para que o processo de aprendizagem pudesse ser consolidado. Assim, a partir de 1998, o Ensino Fundamental foi 
dividido em dois segmentos: Ciclo I, da $1^{\mathrm{a}}$ à $4^{\mathrm{a}}$ séries, e Ciclo II, da $5^{\mathrm{a}}$ à $8^{\mathrm{a}}$ séries; onde a possibilidade de reprovação se restringe ao final do ciclo. $\mathrm{O}$ argumento para utilização deste modelo partiu do pressuposto que reprovações seguidas, com o consequente atraso em idade, constituem fator de estímulo à evasão em vez de contribuir para ganhos de aprendizagem dos alunos. Este sistema causa polêmica, tanto entre os educadores como na sociedade. No entanto, não é objetivo deste trabalho aprofundar esta questão, restringindo somente a mencionar o mecanismo dos ciclos.

As políticas educacionais mencionadas acima aliadas com a diminuição das taxas de crescimento populacional no final da década de 90, conforme Tabela 2, diminuíram o ritmo de crescimento das matrículas nos Ensinos Fundamental e Médio no Brasil nos anos 2000, quando comparado com a década anterior. No período pós-2000, as matrículas na Educação Básica no país praticamente se estabilizaram em torno de 48 milhões de alunos: caíram no Ensino Fundamental e cresceram, ligeiramente, no Ensino Médio. (FAPESP, 2010)

Tabela 2

Taxa de crescimento anual da população de 1980 a 2007 (IBGE, 2010).

\begin{tabular}{lccc} 
Grande regiäo & \multicolumn{3}{c}{ Taxa de crescimento anual da populaçåo (\%) } \\
\cline { 2 - 4 } & $1980-1990$ & $1990-2000$ & $2000-2007$ \\
\hline Brasil & 2,1 & 1,6 & 1,4 \\
Estado de São Paulo & 2,4 & 1,7 & 1,6 \\
Norte & 4,3 & 2,7 & 2,3 \\
Nordeste & 2,0 & 1,3 & 1,2 \\
Sudeste & 2,0 & 1,5 & 1,4 \\
Sul & 1,5 & 1,4 & 1,3 \\
Centro-Oeste & 3,4 & 2,3 & 2,0 \\
\hline
\end{tabular}

Além do número absoluto de matrículas, o indicador taxa de matrícula é essencial para avaliar a questão da expansão na educação brasileira. A taxa de matrícula pode ser formulada como taxa líquida ou taxa bruta. A taxa líquida corresponde à relação entre o número de jovens numa dada faixa etária (no ensino superior, em geral, entre 18 e 24 anos) matriculados no ensino superior e o total de jovens da faixa etária considerada. A taxa bruta relaciona o número de matriculados no ensino superior (independentemente da idade) com o número de jovens na faixa etária considerada. Para avaliar o esforço na democratização do acesso da população ao ensino, a taxa bruta parece ser um indicador melhor do que a taxa líquida. A taxa bruta indica que o país forma mais pessoas no ensino e aumenta, assim, o nível de 
escolaridade da população, que é, de fato, o fator mais relevante em termos de qualificação da mão de obra e da elevação do nível de escolarização da população. No contexto da sociedade do conhecimento, com a capacidade de inserção internacional das economias dependendo cada vez mais de suas possibilidades de atender à crescente demanda de altos níveis de conhecimento, o papel atribuído à educação é crucial. Os requisitos para a cidadania e as demandas do mercado de trabalho definem a necessidade de cidadãos com uma forte base de educação geral e capacidade de apropriação de informações. Com isso, em função das imensas disparidades que caracterizam a sociedade brasileira, delineiam-se enormes desafios à área governamental.(FAPESP, 2010)

Na Tabela 3 (página 42), pode-se observar a taxa de matrícula bruta no ensino superior de diversos países em 1999 e 2006. Percebe-se que o Brasil fica abaixo de México, Argentina e Paraguai mesmo após a expansão do ensino superior ocorrida após os anos 2000. Para entender a dinâmica dessas variações e avaliar as perspectivas de aumento do acesso ao ensino superior, é necessário ir além da análise do número de vagas e de alunos matriculados. O ensino superior não constitui uma parte autônoma do sistema de ensino, e tanto a sua abrangência como a sua qualidade dependem dos níveis anteriores de escolarização, os quais condicionam sua expansão. Nesse sentido, um dos fatores principais responsáveis pela histórica baixa taxa de matrícula no ensino superior brasileiro decorre de gargalos educacionais localizados em etapas anteriores a ele, nos ensinos fundamental e médio. $\mathrm{O}$ aumento da oferta no ensino superior é diretamente condicionado pelo número de concluintes do nível de ensino que lhe é imediatamente anterior. (FAPESP, 2010) Adiante será feita uma análise dos ingressantes e concluintes dos ensinos fundamentais, médio e superior. 
Tabela 3

Taxa de matrícula bruta no ensino superior de 1999 e 2006

\begin{tabular}{|c|c|c|}
\hline \multirow{2}{*}{ Países selecionados } & \multicolumn{2}{|c|}{ Taxa de matrícula bruta (\%) (1) (2) } \\
\hline & 1999 & 2006 \\
\hline Grécia & 46,8 & 94,9 \\
\hline Finlândia & 82,4 & 93,2 \\
\hline Coreia do Sul & 66,0 & 92,6 \\
\hline Cuba & 20,5 & 87,9 \\
\hline Estados Unidos & 73,0 & 81,8 \\
\hline Dinamarca & 56,1 & 79,9 \\
\hline Nova Zelândia & 64,3 & 79,7 \\
\hline Suécia & 63,5 & 79,0 \\
\hline Noruega & 66,2 & 77,5 \\
\hline Islândia & 40,0 & 72,9 \\
\hline Austrália & 65,4 & 72,7 \\
\hline Espanha & 56,7 & 67,4 \\
\hline Itália & 47,1 & 67,0 \\
\hline Argentina & 48,5 & 63,8 \\
\hline Bélgica & 56,7 & 62,8 \\
\hline Canadá & 60,3 & 62,4 \\
\hline Holanda & 49,5 & 59,8 \\
\hline Reino Unido & 59,7 & 59,3 \\
\hline Irlanda & 45,9 & 58,8 \\
\hline Israel & 48,4 & 57,6 \\
\hline Japão & 45,1 & 57,3 \\
\hline França & 52,4 & 56,2 \\
\hline Portugal & 45,2 & 54,5 \\
\hline Chile & 37,6 & 46,6 \\
\hline Suíça & 35,9 & 45,8 \\
\hline Panamá & 40,6 & 45,5 \\
\hline Bolívia & 32,9 & 40,6 \\
\hline Peru & . & 35,1 \\
\hline Colômbia & 22,0 & 30,8 \\
\hline Filipinas & 28,7 & 28,5 \\
\hline México & 18,2 & 26,1 \\
\hline Paraguai & 13,0 & 25,5 \\
\hline Brasil & 14,5 & 25,5 \\
\hline Costa Rica & 16,0 & 25,3 \\
\hline China & 6,4 & 21,6 \\
\hline Índia & . & 11,8 \\
\hline
\end{tabular}

Fonte: Education for All Global Monotoring Report (Unesco, 2009).

Além da baixa taxa bruta no ensino superior, outra característica no Brasil é que a taxa bruta é bastante superior à taxa líquida. Isso ocorre porque um alto percentual de estudantes está acima da média de idade apropriada por dois motivos. Em primeiro lugar, a elevada taxa de reprovação e de abandono dos estudos, com retorno posterior, que caracteriza o ensino médio, 
cujo efeito é a elevação da idade média de ingresso no ensino superior (maior que 18 anos). O segundo motivo está associado à ampliação da oferta de ensino e às exigências do mercado de trabalho. Nessas condições, um grande número de pessoas que abandonaram os estudos na conclusão do ensino médio e se inseriram no mercado de trabalho volta a procurar uma formação em nível superior.

Tabela 4

Evolução das taxas de escolarização bruta e líquida na educação superior de 2001 a 2009

\begin{tabular}{|c|c|c|c|c|c|c|c|c|c|c|c|c|c|c|c|c|c|c|}
\hline \multirow{3}{*}{$\begin{array}{l}\text { Brasil// } \\
\text { Regiões }\end{array}$} & \multicolumn{18}{|c|}{ Educação Superior (18 a 24 anos) } \\
\hline & \multicolumn{9}{|c|}{ Escolarização Bruta } & \multicolumn{9}{|c|}{ Escolarização Líquida } \\
\hline & 2001 & 2002 & 2003 & 2004 & 2005 & 2006 & 2007 & 2008 & 2009 & 2001 & 2002 & 2003 & 2004 & 2005 & 2006 & 2007 & 2008 & 2009 \\
\hline Brasil & 15,1 & 16,6 & 18,6 & 18,6 & 19,9 & 22,6 & 24,3 & 25,5 & 26,7 & 8,9 & 9,8 & 10,6 & 10,5 & 11,2 & 12,6 & 13,1 & 13,7 & 14,4 \\
\hline Centro- Oeste & 18,2 & 21,8 & 23,6 & 23,2 & 25,9 & 27,0 & 28,8 & 31,1 & 32,6 & 9,7 & 11,9 & 12,3 & 12,2 & 14,0 & 14,8 & 15,6 & 16,3 & 17,9 \\
\hline Nordeste & 9,1 & 9,5 & 10,9 & 11,1 & 11,9 & 14,3 & 15,9 & 16,9 & 18,4 & 5,1 & 5,1 & 5,8 & 5,9 & 6,1 & 7,1 & 7,7 & 8,3 & 9,4 \\
\hline Norte & 11,3 & 15,3 & 14,7 & 12,2 & 14,6 & 17,0 & 19,3 & 21,7 & 23,7 & 5,2 & 6,7 & 6,1 & 5,7 & 7,0 & 7,6 & 9,0 & 9,9 & 11,0 \\
\hline Sudeste & 17,3 & 19,0 & 21,2 & 22,0 & 23,3 & 26,7 & 28,6 & 29,4 & 30,1 & 10,9 & 12,0 & 12,8 & 13,0 & 13,8 & 15,7 & 16,4 & 16,6 & 16,8 \\
\hline Sul & 21,3 & 22,8 & 26,7 & 26,5 & 27,8 & 29,7 & 30,8 & 32,9 & 33,5 & 12,7 & 13,7 & 15,9 & 15,3 & 16,2 & 17,1 & 16,8 & 18,7 & 19,2 \\
\hline
\end{tabular}

Fonte: IBGE/ PNAD; elaborado por MEC/Inep (2010).

O primeiro Plano Nacional de Educação (PNE) foi elaborado em 1996, para vigorar entre os anos de 2001 a 2010. A meta definida no PNE em 1996 foi de 30\% dos jovens de 18 a 24 anos matriculados na educação superior sendo 40\% destas matrículas em escola pública. Em 2014, um novo Plano Nacional de Educação foi aprovado e o percentual de 30\% dos jovens de 18 a 24 anos matriculados na educação superior foi elevado para 33\%. O percentual de 40\% na rede pública manteve-se. Além disto, foi fixado um percentual de 50\% para a taxa de matrícula bruta no ensino superior. O Censo da Educação Superior de 2011 retratava 15\% dos jovens da faixa etária de 18-24 anos cursando a educação superior, conforme Tabela 5:

Tabela 5

Alunos matriculados na graduação

\begin{tabular}{lrrr}
\hline \multicolumn{1}{c}{$\begin{array}{c}\text { Brasil/ } \\
\text { Regiões }\end{array}$} & $\begin{array}{c}\text { População (18 a 24 } \\
\text { anos) }\end{array}$ & $\begin{array}{c}\text { Frequenta curso de } \\
\text { graduação (18 a 24 } \\
\text { anos) }\end{array}$ & \% Alunos \\
\cline { 2 - 4 } Brasil & 22.497 .453 & 3.283 .368 & $15 \%$ \\
Norte & 2.098 .423 & 217.642 & $10 \%$ \\
Nordeste & 6.399 .491 & 664.870 & $10 \%$ \\
Sudeste & 9.113 .639 & 1.471 .314 & $16 \%$ \\
Sul & 3.128 .684 & 582.965 & $19 \%$ \\
Centro-Oeste & 1.757 .216 & 346.577 & $20 \%$ \\
\hline
\end{tabular}

Fonte: IBGE e Censo da Educação Superior/MEC/INEP/DEED (2010). 
Cabe ressaltar a diferença entre as regiões Norte e Nordeste, retratando $10 \%$ da população desta faixa etária no curso de graduação e as regiões Sul e Centro Oeste retratando 19\% e $20 \%$, respectivamente.

Tabela 6

População total de 15 a 17 anos, matrículas no ensino médio total e relativa á população de 15 a 17 anos e taxas de matrícula no Brasil e no Estado de São Paulo de 1998 a 2006

\begin{tabular}{|c|c|c|c|c|c|c|}
\hline \multirow[b]{2}{*}{ Área geográfica } & \multicolumn{2}{|c|}{ População } & \multicolumn{2}{|c|}{ Matrículas no ensino médio } & \multirow{2}{*}{$\begin{array}{c}\text { Taxa de } \\
\text { matrícula } \\
\text { bruta }\end{array}$} & \multirow{2}{*}{$\begin{array}{l}\text { Taxa de } \\
\text { matrícula } \\
\text { líquida }\end{array}$} \\
\hline & Total & $\begin{array}{l}\text { De } 15 \text { a } 17 \\
\text { anos }\end{array}$ & Total & $\begin{array}{c}\text { Da população } \\
\text { de } 15 \text { a } 17 \text { anos }\end{array}$ & & \\
\hline \multicolumn{7}{|c|}{2002} \\
\hline Brasil & 174.632 .960 & 10.353.123 & 8.710 .584 & 4.161.691 & 84,1 & 40,2 \\
\hline Estado de São Paulo & 38.177.742 & 2.062 .967 & 2.065 .270 & 1.310 .772 & 100,1 & 63,5 \\
\hline \multicolumn{7}{|c|}{2003} \\
\hline Brasil & 176.871 .437 & 10.481 .393 & 9.072 .942 & 4.470 .266 & 86,6 & 42,6 \\
\hline Estado de São Paulo & 38.709 .320 & 2.204 .978 & 2.099.910 & 1.384 .826 & 95,2 & 62,8 \\
\hline \multicolumn{7}{|c|}{2004} \\
\hline Brasil & 181.581.024 & 10.742 .044 & 9.169.357 & 4.660 .419 & 85,4 & 43,4 \\
\hline Estado de São Paulo & 39.825 .226 & 2.196 .187 & 2.045 .851 & 1.406 .202 & 93,2 & 64,0 \\
\hline \multicolumn{7}{|c|}{2005} \\
\hline Brasil & 184.184.264 & 10.658 .958 & 9.031 .302 & 4.687 .574 & 84,7 & 44,0 \\
\hline Estado de São Paulo & 40.442 .795 & 2.184 .556 & 1.913 .848 & 1.349.521 & 87,6 & 61,8 \\
\hline \multicolumn{7}{|c|}{2006} \\
\hline Brasil & 186.770 .562 & 10.424 .755 & 8.906 .820 & 4.723.399 & 85,4 & 45,3 \\
\hline Estado de São Paulo & 41.055 .434 & 2.032 .494 & 1.813 .795 & 1.319 .078 & 89,2 & 64,9 \\
\hline \multicolumn{7}{|c|}{ Taxa de Crescimento 2002-2006 (\%) } \\
\hline Brasil & 7,0 & 0,7 & 2,3 & 13,5 & 1,6 & 12,7 \\
\hline Estado de São Paulo & 7,5 & $-1,5$ & $-12,2$ & 0,6 & $-10,9$ & 2,1 \\
\hline
\end{tabular}

Fonte: INEP. Censo do Ensino Superior; IBGE. Pesquisa Nacional por Amostra de Domicílio (PNAD, 2010).

Os dados da Tabela 7 abaixo trazem números absolutos de alunos matriculados por série no Ensino Fundamental dos anos de 2001 a 2010. É possível visualizar no Ensino Fundamental que o número de concluintes sobre ingressantes aumentou de 2001 a 2010 saindo de 54\% para 96\%. O sistema de ciclos mencionado anteriormente contribuiu para a elevação deste percentual. 
Tabela 7

Evolução do Número de Matrículas totais e por série do Ensino Fundamental de 2001 a 2010

\begin{tabular}{|c|c|c|c|c|c|c|c|c|c|c|c|}
\hline Ano & Total & PRÉ & $1^{\mathrm{a}}$ série & $2^{\mathrm{a}}$ série & $3^{\mathrm{a}}$ série & $4^{\mathrm{a}}$ série & $5^{\mathrm{a}}$ série & $6^{a}$ série & $7^{\mathrm{a}}$ série & $8^{\mathrm{a}}$ série & $\begin{array}{l}\text { Concluinte/ } \\
\text { Ingressante }\end{array}$ \\
\hline 2001 & 35.298.089 & & 5.978.272 & 4.782.389 & 4.625 .014 & 4.342.009 & 4.763 .018 & 3.963.575 & 3.622 .550 & 3.221.262 & $54 \%$ \\
\hline 2002 & 35.150 .362 & & 5.818 .388 & 4.764.926 & 4.492 .856 & 4.304.217 & 4.814.111 & 3.960 .133 & 3.657 .202 & 3.338 .529 & $57 \%$ \\
\hline 2003 & 34.430 .749 & & 5.575.157 & 4.709.176 & 4.434 .820 & 4.199.909 & 4.691 .702 & 3.993 .340 & 3.560 .209 & 3.274 .370 & $59 \%$ \\
\hline 2004 & 34.012 .434 & 739.714 & 4.996 .791 & 4.548 .305 & 4.334.171 & 4.155.147 & 4.533 .470 & 3.990 .245 & 3.514 .653 & 3.199.938 & $64 \%$ \\
\hline 2005 & 33.534.561 & 908.052 & 4.816 .489 & 4.417.501 & 4.177 .063 & 4.146 .400 & 4.520 .875 & 3.891 .386 & 3.476 .179 & 3.180 .616 & $66 \%$ \\
\hline 2006 & 33.282.663 & 1.336 .992 & 4.602.744 & 4.317.289 & 4.060 .900 & 4.020 .675 & 4.517 .883 & 3.881 .120 & 3.409.231 & 3.135 .829 & $68 \%$ \\
\hline 2007 & 32.122.273 & 1.957.337 & 4.029.748 & 4.102.657 & 3.856.011 & 3.836 .615 & 4.277.648 & 3.769 .816 & 3.278 .540 & 3.013.901 & $75 \%$ \\
\hline 2008 & 32.086 .700 & 2.266.667 & 3.749 .503 & 3.899.166 & 3.884 .405 & 3.820 .698 & 4.231 .765 & 3.760 .732 & 3.365.933 & 3.107.831 & $83 \%$ \\
\hline 2009 & 31.705 .528 & 2.528 .631 & 3.582 .152 & 3.706 .870 & 3.661 .063 & 3.816 .902 & 4.199.197 & 3.703 .875 & 3.354.061 & 3.152.777 & $88 \%$ \\
\hline 2010 & 31.005.341 & 2.883.191 & 3.216 .170 & 3.589.029 & 3.489 .360 & 3.577.958 & 4.150.365 & 3.675 .161 & 3.333.061 & 3.091 .046 & $96 \%$ \\
\hline Média & 33.262 .870 & 1.802 .941 & 4.636.541 & 4.283 .731 & 4.101 .566 & 4.022 .053 & 4.470 .003 & 3.858.938 & 3.457.162 & 3.171 .610 & $68 \%$ \\
\hline
\end{tabular}

Fonte: MEC/ Inep (2010). 
Ao analisar os números brutos de matrículas de 2001 a 2010 do Ensino Médio, conforme Tabela 8 é possível constatar um número maior de alunos que ingressam no Médio comparado aos que concluem o Ensino Fundamental. Isso se deve ao fato de muitos estudantes retomarem seus estudos no Ensino Médio mesmo depois de anos de conclusão do Ensino Fundamental devido à demanda do mercado.

Tabela 8

Evolução do Número de Matrículas totais e por série do Ensino Médio de 2001 a 2010

\begin{tabular}{|c|c|c|c|c|c|}
\hline Ano & Total & $1^{\circ}$ ano & $2^{\circ}$ ano & $3^{\circ}$ ano & $\begin{array}{l}\text { Concluinte/ } \\
\text { Ingressante }\end{array}$ \\
\hline 2001 & 8.398 .008 & 3.438 .523 & 2.479 .473 & 2.480 .012 & $72 \%$ \\
\hline 2002 & 8.710 .584 & 3.481 .556 & 2.585 .801 & 2.643.227 & $76 \%$ \\
\hline 2003 & 9.072 .942 & 3.687.333 & 2.736.381 & 2.649 .228 & $72 \%$ \\
\hline 2004 & 9.169 .357 & 3.782 .921 & 2.885 .874 & 2.500 .562 & $66 \%$ \\
\hline 2005 & 9.031 .302 & 3.660 .934 & 2.846.877 & 2.523 .491 & $69 \%$ \\
\hline 2006 & 8.906.820 & 3.651 .903 & 2.772 .967 & 2.481 .950 & $68 \%$ \\
\hline 2007 & 8.369.369 & 3.440 .048 & 2.629.339 & 2.299 .982 & $67 \%$ \\
\hline 2008 & 8.366 .100 & 3.409 .015 & 2.615.903 & 2.341 .182 & $69 \%$ \\
\hline 2009 & 8.337.160 & 3.430 .376 & 2.574 .195 & 2.332 .589 & $68 \%$ \\
\hline 2010 & 8.357.675 & 3.471 .986 & 2.578.949 & 2.306 .740 & $66 \%$ \\
\hline Soma & 86.719.317 & 35.454 .595 & 26.705 .759 & 24.558.963 & $69 \%$ \\
\hline Média & 8.671.932 & 3.545 .460 & 2.670 .576 & 2.455 .896 & $69 \%$ \\
\hline
\end{tabular}

Fonte: MEC/ Inep (2010).

No Ensino Médio, as elevadas taxas de expansão das matrículas verificadas nos anos 1990, especialmente no último quinquênio, associaram-se inicialmente à forte expansão da demanda. Esse crescimento foi impulsionado tanto pelo maior contingente de concluintes do Ensino Fundamental quanto pelo significativo retorno ao sistema de ensino de jovens que já haviam abandonado os estudos, sustentado especialmente pela percepção da necessidade de maior escolaridade como requisito para ingresso no mercado de trabalho. (FAPESP, 2010)

Abaixo, na Figura 8, há o comparativo entre o número de matrículas no ensino médio no Estado de São Paulo e no Brasil. Percebe-se a partir de 1999 uma grande ascensão de matriculas no Brasil, fato que não se reflete no Estado de São Paulo. 


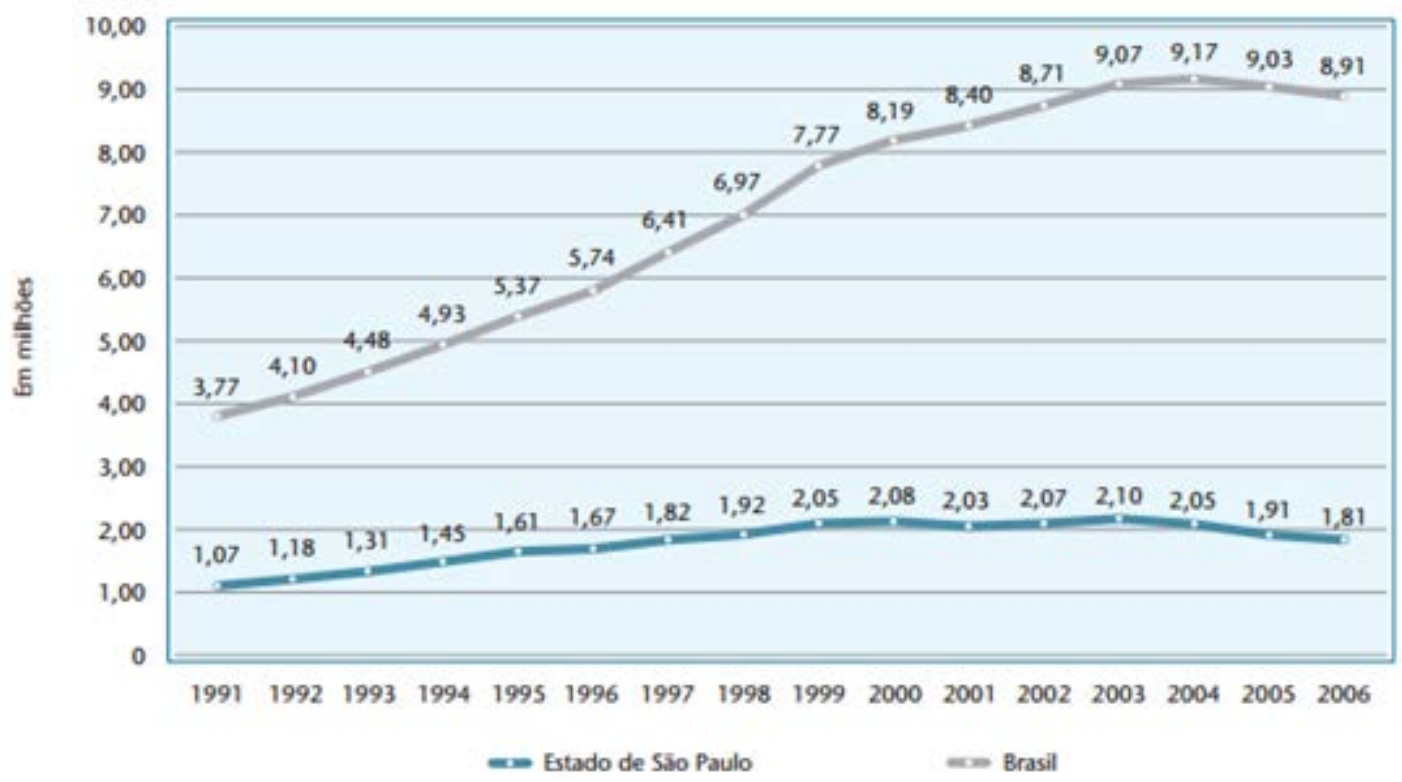

Figura 8. Matrículas no ensino médio no Brasil e Estado de São Paulo de 1991 a 2006. Fonte: Censo da Educação Básica - microdados (INEP, 2010).

Ao compararmos o número de concluintes do Ensino Médio com os ingressantes do Ensino Superior percebe-se que o número de ingressantes é menor que o de concluintes. A média de concluintes de 2001 a 2010 no Ensino Médio é de 2,5 milhões de alunos e de ingressantes no mesmo período do Superior é de 1,8 milhões, conforme Tabela 9. No entanto, como demonstrado pela taxa de matrícula bruta e líquida, não se tratam dos mesmos alunos que concluíram o Ensino Médio e sim de pessoas que após alguns anos de término do Ensino Médio, retornam para cursar uma graduação.

Outro dado relevante é o número de matrículas, ingressantes e concluintes mais que dobram no período analisado, principalmente concluintes, elevando a taxa de concluintes sobre ingressantes de $38 \%$ para $45 \%$ no período analisado. 
Tabela 9

Evolução do Número de Matrículas, Ingressantes e Concluintes do Ensino Superior de 2001 a 2010

\begin{tabular}{rrrrc}
\hline \multirow{2}{*}{ Ano } & \multicolumn{1}{l}{ Matrículas } & \multicolumn{1}{l}{ Ingressantes } & \multicolumn{1}{l}{ Concluintes } & $\begin{array}{c}\text { Concluinte/ } \\
\text { Ingressante }\end{array}$ \\
\hline 2001 & 3.036 .113 & 1.043 .308 & 396.119 & $38 \%$ \\
2002 & 3.520 .627 & 1.431 .893 & 467.972 & $33 \%$ \\
2003 & 3.936 .933 & 1.554 .664 & 532.228 & $34 \%$ \\
2004 & 4.223 .344 & 1.646 .414 & 633.363 & $38 \%$ \\
2005 & 4.567 .798 & 1.805 .102 & 730.484 & $40 \%$ \\
2006 & 4.883 .852 & 1.965 .314 & 762.633 & $39 \%$ \\
2007 & 5.250 .147 & 2.138 .241 & 786.611 & $37 \%$ \\
2008 & 5.808 .017 & 2.336 .899 & 870.386 & $37 \%$ \\
2009 & 5.954 .021 & 2.065 .082 & 959.197 & $46 \%$ \\
2010 & 6.379 .299 & 2.182 .229 & 973.839 & $45 \%$ \\
Média & 4.756 .015 & 1.816 .915 & 711.283 & $39 \%$ \\
\hline
\end{tabular}

Fonte: MEC/ Inep (2010).

Com relação às instituições de ensino superior, dados do MEC-INEP de 2011, retratam 2365 instituições de ensino superior no país, número em ascensão desde o ano de 2000; conforme a Figura 9. Deste total, 2081 instituições são privadas e 284 públicas (12\%). Desde a década de 60 o crescimento no setor privado vem se acentuando, tendo grandes variações nas décadas de 70, 90 e anos 2000.

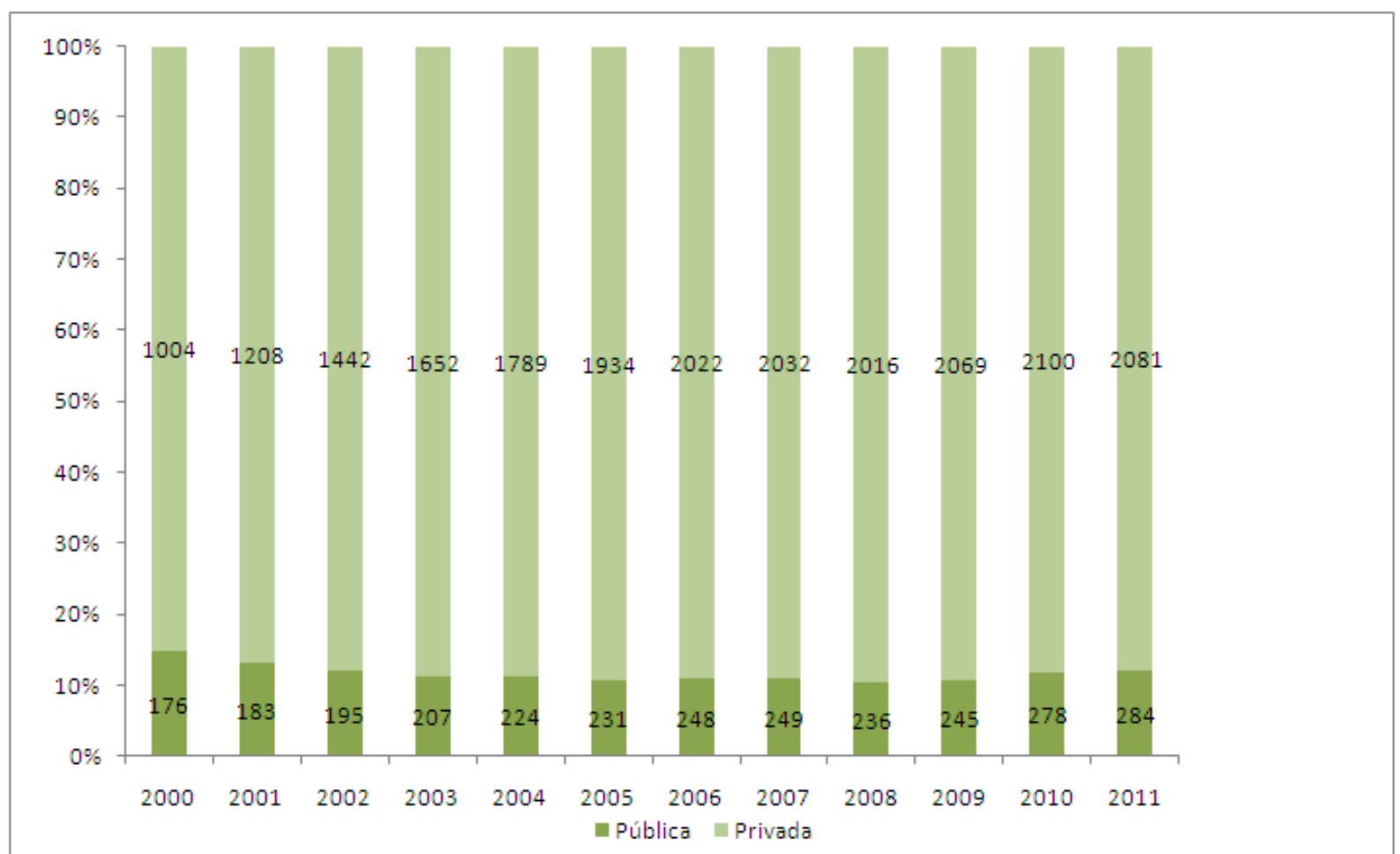

Figura 9. Proporção entre instituições de educação superior pública e privada de 2000 a 2011 (Censo da Educação Superior/MEC/INEP/DEED, 2011). 
Em 2011, dados obtidos constata-se 6.739.689 alunos matriculados em cursos de graduação. Destes, 4.966.374 alunos em instituições privadas (74\%).

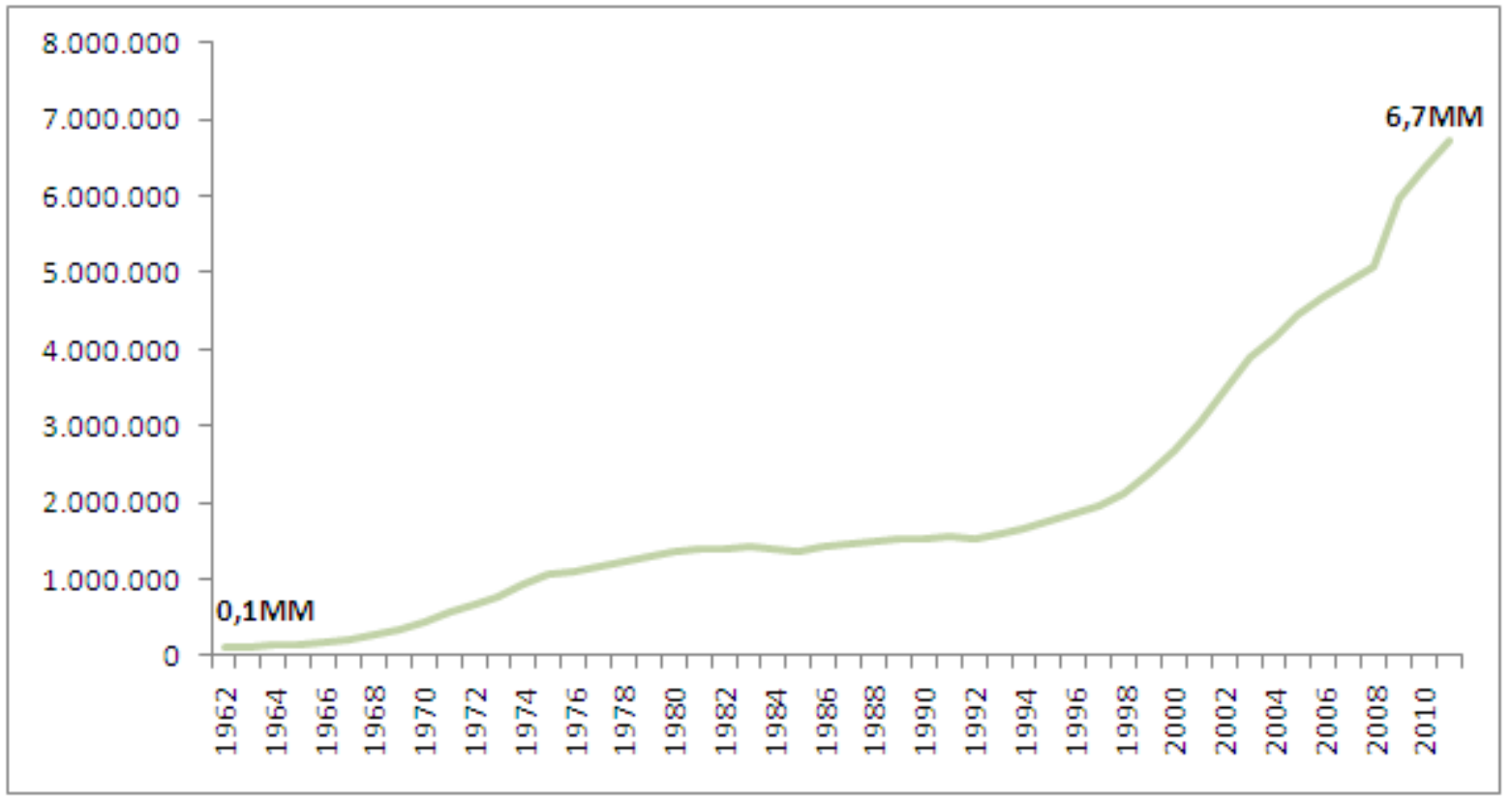

Figura 10. Evolução do número de matrículas na educação superior no Brasil - 1962-2011 (Censo da Educação Superior/MEC/INEP/DEED, 2011).

Dentre as áreas de conhecimento com mais matrículas, destacam-se Ciências Sociais, Negócios e Direitos com 41,5\%, seguida pela área da Educação com 21,2\%, conforme Figura 11:

\begin{tabular}{lr}
\multicolumn{1}{c|}{ Área Geral do Conhecimento } & $\%$ \\
\hline Total & 100,0 \\
\hline Ciências sociais, negócios e direito & 41,5 \\
\hline Educação & 21,2 \\
\hline Saúde e bem estar social & 14,0 \\
\hline Engenharia, produção e construção & 9,9 \\
\hline Ciências, matemática e computação & 6,5 \\
\hline Humanidades e artes & 2,3 \\
\hline Agricultura e veterinária & 2,3 \\
\hline Serviços & 2,2 \\
\hline
\end{tabular}

Figura 11. Distribuição do número de matrículas por área geral de conhecimento em 2010 (Censo da Educação Superior/MEC/INEP/DEED, 2010).

Apesar dos avanços nos últimos anos em número de matrículas, o que se percebe é a migração destas matrículas para o setor privado, conforme Tabela 10. 
Tabela 10

Alunos matriculados na graduação

\begin{tabular}{llrrrrr}
\hline Ano & Total & Público & $\%$ & \multicolumn{3}{c}{ Privado } \\
\hline 2001 & 3.036 .113 & 944.584 & $31 \%$ & 2.091 .529 & $69 \%$ \\
2002 & 3.520 .627 & 1.085 .977 & $31 \%$ & 2.434 .650 & $69 \%$ \\
2003 & 3.936 .933 & 1.176 .174 & $30 \%$ & 2.760 .759 & $70 \%$ \\
2004 & 4.223 .344 & 1.214 .317 & $29 \%$ & 3.009 .027 & $71 \%$ \\
2005 & 4.567 .798 & 1.246 .704 & $27 \%$ & 3.321 .094 & $73 \%$ \\
2006 & 4.883 .852 & 1.251 .365 & $26 \%$ & 3.632 .487 & $74 \%$ \\
2007 & 5.250 .147 & 1.335 .177 & $25 \%$ & 3.914 .970 & $75 \%$ \\
2008 & 5.808 .017 & 1.552 .953 & $27 \%$ & 4.255 .064 & $73 \%$ \\
2009 & 5.954 .021 & 1.523 .864 & $26 \%$ & 4.430 .157 & $74 \%$ \\
2010 & 6.379 .299 & 1.643 .298 & $26 \%$ & 4.736 .001 & $74 \%$ \\
2011 & 6.739 .689 & 1.773 .315 & $26 \%$ & 4.966 .374 & $74 \%$ \\
\hline
\end{tabular}

Fonte: Censo da Educação Superior/MEC/INEP/DEED (2011)

O próximo capítulo abordará a educação inclusiva e, principalmente, dados das pessoas com deficiência ao ensino superior.

\subsection{Educação Inclusiva}

No século XIX, a resposta para a incapacidade das escolas em lidar com a aprendizagem dos alunos com deficiência foi a criação das classes especiais. Os alunos considerados “difíceis” eram enviados para as classes especiais. O surgimento das salas especiais foi o primeiro passo para a educação das pessoas com deficiência, que até então ficavam confinadas em manicômios e asilos. A disseminação das escolas e classes especiais só ocorreu definitivamente após a Segunda Guerra Mundial no século XX. Por muitas décadas, este sistema apartado de ensino perdurou, de forma a não misturar alunos "normais" com “anormais”. Na tentativa de inserir o aluno com deficiência nas salas de aula regulares, as adaptações curriculares ou metodológicas não ocorreram, assim, a criança era matriculada nas classes especiais no sistema de ensino regular. Nos espaços do ambiente escolar, era o educando que deveria se adaptar, e não o processo inverso. Alunos que eram enviados às salas de ensino regular fracassavam uma vez que não tinham as adaptações e apoios necessários para terem as mesmas oportunidades de ensino que os demais pares. Em vista do contexto das dificuldades ocorridas nesse período, uma nova proposta foi veiculada, a da inclusão, questionando a proposta da fase anterior. (Castilho, 2012) 
Para Sassaki, (1997, p. 41) inclusão é:

"um processo pelo qual a sociedade se adapta para poder incluir em seus
sistemas sociais gerais pessoas com necessidades especiais e,
simultaneamente, estas se preparam para assumir seus papéis na sociedade...
. Incluir é trocar, entender, respeitar, valorizar, lutar contra exclusão, transpor
barreiras que a sociedade criou para as pessoas. É oferecer o
desenvolvimento da autonomia, por meio da colaboração de pensamentos e
formulação de juízo de valor, de modo a poder decidir, por si mesmo, como
agir nas diferentes circunstâncias da vida.”

O ápice da discussão sobre inclusão ocorreu em Salamanca, na Espanha, em 1994, com a elaboração da Declaração de Salamanca (1994), na qual 88 países se comprometeram em implantar uma educação inclusiva. “Cada escola, como um todo, é responsável por promover atitudes positivas frente à inclusão. A preparação dos professores passa a ser papel das universidades e deve ocorrer de forma a capacitá-los para a demanda, de forma que saibam identificar as necessidades de seus alunos” (Unesco, 1994, p. 1).

Apesar de bastante defendido nas últimas décadas, o conceito de inclusão é antigo. Na década de 20 foi abordado por Vigotski. O psicólogo menciona a necessidade das crianças com deficiência permanecerem juntas das crianças sem deficiência.

"Dessa maneira, reagindo ao enfoque quantitativo, Vigotski criticou a forma de tratamento que os estudiosos adotavam em relação á criança com deficiência. Esses estudiosos se referiam a ela como uma pessoa enferma e não consideravam a deficiência como um processo em seu caráter dinâmico. Para Vigotski, ao contrário, as crianças com deficiência devem ser educadas de forma mais semelhante possível às crianças em geral, inclusive educar conjuntamente.” (Rossetto, 2009, p. 43)

\footnotetext{
“Vigotski opunha-se às ideias de biologizar as concepções existentes sobre o desenvolvimento de crianças deficientes, enfatizando que a deficiência não se caracteriza somente pelo caráter biológico, mas principalmente pelo caráter social. Por meio da teorização do desenvolvimento psíquico, fazia a defesa de que, no desenvolvimento das crianças com deficiência, atuam as mesmas leis que no desenvolvimento das crianças em geral. Desse modo, não fazia distinção entre o quadro evolutivo da criança 'normal' e o quadro da criança com deficiência, reafirmando a necessidade de uma mesma escola para todas as crianças.” (Rossetto, 2009, p. 30)
} 
Portanto, o conceito da inclusão surgiu no século XX, porém somente a partir das últimas décadas se solidificou como sendo a melhor alternativa para a educação dos alunos com deficiência.

Em suma, a escola inclusiva permite, na prática, evidenciar o fundamento de que todas as crianças devem aprender juntas, com dificuldades ou diferenças que apresentam. Isto se reporta à elaboração de planos que reconheçam e respondam às necessidades dos alunos. Em outras palavras, acomodar estilos, ritmos de aprendizagem, independentemente de suas condições físicas, intelectuais, sociais, emocionais, lingüísticas e outras. (Baumel, 1998)

Ao falar sobre escolas inclusivas, normalmente o ensino abordado pela literatura refere-se ao fundamental. Inclusão no ensino superior é algo recente, visto que anteriormente nem se tinham dados oficiais da quantidade de pessoas com deficiência na educação superior. É fato que, a pessoa com deficiência após transpor a barreira do vestibular e ingressar em uma instituição de ensino superior, depara-se com outras dificuldades a fim de obter o diploma. $\mathrm{O}$ ingresso constitui-se como mais uma etapa no processo de inclusão.

\begin{abstract}
“O desafio, então, é construirmos não um direito ao Ensino Superior em termos de acesso universal e obrigatório a todos, mas sim no sentido de uma progressiva expansão e enquanto garantia àqueles que aspiram um diploma e formação superior, aperfeiçoada as formas de assegurar igualdade de oportunidades no acesso e permanência, inclusive em instituições altamente competitivas. As condições para manter esse aluno, nos vários espaços da universidade, além da garantia de seu sucesso na vida acadêmica, estão relacionadas à democratização do Ensino Superior. Neste contexto, é preciso pensar em práticas diferenciadas, tais como disponibilidade de materiais adequados, tecnologias e redes de suporte.” (Moehlecke, 2004, p.98).
\end{abstract}

O último Censo de pessoas com deficiência, realizado em 2010 pela Secretaria dos Direitos da Pessoa com Deficiência do Governo do Estado de São Paulo mostrou que no Brasil são cerca de 40 milhões de pessoas classificadas com alguma deficiência.

Ao analisar dados da Educação Superior, segundo dados do Instituto Nacional de Estudos e Pesquisas (INEP), em 2001 havia 2.173 alunos com deficiência matriculados nas instituições de ensino superior. Em 2010 este número saltou para 20.287 (834\% de crescimento). Desse contingente de 20 mil pessoas, em 2010, 66\% das matrículas estavam em instituições de ensino superior privada. Ao observar o percentual de pessoas com deficiência na graduação sobre o total de alunos, em 2001 a representatividade era de 0,1\% e em 2010 alcançou 0,3\%. 
Apesar do incremento percentual ocorrido entre 2001 e 2010, o número de candidatos ainda é incipiente. Um dos fatores que apontam a razão destes números é a exclusão enorme que os alunos com necessidades educacionais especiais enfrentam no ensino médio. Dados do Censo Escolar MEC/INEP de 2001 e 2010, relativos a escolas comuns e escolas especiais, apontam que, do total de 8.398.008 alunos matriculados no Ensino Médio em 2001 somente 3.342 tinham alguma deficiência (0,04\% do total) e em 2010, dos 8.357 .675 alunos, 28.667 apresentavam alguma deficiência (0,34\% do total). O crescimento de alunos com deficiência no ensino médio entre 2001 e 2010 assemelha-se com o percentual de crescimento no ensino superior no mesmo período (758\% e 834\%, respectivamente). Magalhães (2010, p.10) refere que “até o início da década de 80, poucas pessoas com deficiência tinham acesso à educação superior no Brasil, isso está associado, inclusive, ao não acesso desta população à educação básica”, fato este comprovado pelo baixo número apresentado ainda em 2001.

Na Tabela 11 é possível observar as taxas de escolarização de pessoas com deficiência e sem deficiência, tanto em países com alta renda como com baixa renda:

Tabela 11

Resultados de educação para respondentes com deficiência e sem deficiência

\begin{tabular}{|c|c|c|c|c|c|c|}
\hline \multirow[t]{2}{*}{ Indivíduos } & \multicolumn{2}{|c|}{ Paises de Baixa Renda } & \multicolumn{2}{|c|}{ Paises de Alta Renda } & \multicolumn{2}{|c|}{ Todos os Paises } \\
\hline & $\begin{array}{c}\text { Não } \\
\text { Deficientes }\end{array}$ & Deficientes & $\begin{array}{c}\text { Não } \\
\text { Deficientes }\end{array}$ & Deficientes & $\begin{array}{c}\text { Não } \\
\text { Deficientes }\end{array}$ & Deficientes \\
\hline \multicolumn{7}{|l|}{ Homens } \\
\hline Conclusão do Fundamental & $55.6 \%$ & $45.6 \% *$ & $72.3 \%$ & $61.7 \% *$ & $61.3 \%$ & $50.6 \% *$ \\
\hline Média de Anos de Educação & 6.43 & $5.63 *$ & 8.04 & $6.60 *$ & 7.03 & $5.96 *$ \\
\hline \multicolumn{7}{|l|}{ Mulheres } \\
\hline Conclusão do Fundamental & $42.0 \%$ & $32.9 \% *$ & $72.0 \%$ & $59.3 \% *$ & $52.9 \%$ & $41.7 \% *$ \\
\hline Média de Anos de Educação & 5.14 & $4.17 *$ & 7.82 & $6.39 *$ & 6.26 & $4.98 *$ \\
\hline \multicolumn{7}{|l|}{$18-49$ anos } \\
\hline Conclusão do Fundamental & $60.3 \%$ & $47.8 \% *$ & $83.1 \%$ & $69.0 \% *$ & $67.4 \%$ & $53.2 \% *$ \\
\hline Média de Anos de Educação & 7.05 & $5.67 *$ & 9.37 & $7.59 *$ & 7.86 & $6.23 *$ \\
\hline \multicolumn{7}{|l|}{$50-59$ anos } \\
\hline Conclusão do Fundamental & $44.3 \%$ & $30.8 \% *$ & $68.1 \%$ & $52.0 \% *$ & $52.7 \%$ & $37.6 \% *$ \\
\hline Média de Anos de Educação & 5.53 & $4.22 *$ & 7.79 & $5.96^{*}$ & 6.46 & $4.91^{*}$ \\
\hline \multicolumn{7}{|l|}{60 ou mais anos } \\
\hline Conclusão do Fundamental & $30.7 \%$ & $21.2 \% *$ & $53.6 \%$ & $46.5 \% *$ & $40.6 \%$ & $32.3 \% *$ \\
\hline Média de Anos de Educação & 3.76 & 3.21 & $5.36^{*}$ & $4.60 *$ & 4.58 & $3.89 *$ \\
\hline
\end{tabular}

Nota: Relatório Mundial sobre a deficiência (2011). As estimativas estão ponderadas usando pesos da WHS pósestratificados, quando disponíveis (pesos de probabilidade quando não) e padronizado por idade. *teste-t sugere diferença significativa de Não Deficientes a um nível de significância de 5\%.

A cultura acadêmica acostumou-se de tal modo a excluir de seus espaços de formação a diversidade humana, representada pela condição de diferença/deficiência, que a inclusão educacional no ensino superior tem sido marcada por enfrentamentos e recuos diante das trajetórias de exclusão vivenciadas por minorias que foram historicamente marginalizadas 
e/ou segregadas em seus processos de educação formal, em função de diferenças étnicas, de raça, de gênero, da condição de deficiência, dentre outras.(Miranda \& Galvão Filho, 2012)

No entanto, estes dados não devem ser desmerecidos, é preciso associá-los a outros fatores presentes no sistema educacional brasileiro, tais como:

“a) o reconhecimento da educação especial como modalidade de ensino é muito recente, (promulgado pela LDB (Lei $\mathrm{n}^{\circ}$ 9.394/96); b) os dados de escolarização dos alunos com deficiência no ensino brasileiro são muito recentes;

c) o direito à educação dos alunos com deficiência delineou-se historicamente como concessão que encobriu parte de sua segregação e da falta de compromisso dos poderes públicos. Estes aparatos legais, sem dúvida, são importantes e necessários para uma educação inclusiva no ensino superior brasileiro, muito embora, por si só não garantam a efetivação de políticas e programas inclusivos. Uma educação que prime pela inclusão deve ter, necessariamente, investimentos em materiais pedagógicos, em qualificação de professores, em infraestrutura adequada para ingresso, acesso e permanência e estar atento a qualquer forma discriminatória. Para tanto, urge a implementação de políticas educacionais que explicitem em seus programas de governo, sobretudo, de que forma as universidades públicas poderão buscar recursos financeiros para equiparar adequadamente as necessidades dessa demanda.” (Moreira, 2005, p. 6)

Referindo-se ao acesso das pessoas com deficiência aos cursos, o Censo da Educação Superior 2011 afirma que 80,7\% dos cursos de graduação garantem recursos de tecnologia assistiva $^{3}$ disponíveis às pessoas com deficiência. Esses recursos disponíveis às pessoas com deficiência são mencionados abaixo:

- $\quad$ Material em braile;

- $\quad$ Material em áudio;

- $\quad$ Sistema de síntese de voz;

- $\quad$ Tradutor e intérprete de língua brasileira de sinais;

- $\quad$ Guia-Intérprete;

- $\quad$ Material didático em língua brasileira de sinais;

\footnotetext{
${ }^{3}$ Segundo o Comitê de Ajudas Técnicas , tecnologia assistiva é uma área do conhecimento que engloba produtos, recursos, metodologias, estratégias, práticas e serviços que objetivam promover a funcionalidade, relacionada à atividade e participação de pessoas com deficiência, incapacidades ou mobilidade reduzida, visando sua autonomia, independência, qualidade de vida e inclusão social.
} 
- $\quad$ Inserção da disciplina de língua brasileira de sinais no curso;

- $\quad$ Material didático em formato impresso acessível;

- $\quad$ Material didático digital acessível;

- $\quad$ Material pedagógico tátil;

- $\quad$ Recursos de acessibilidade à comunicação;

- $\quad$ Recursos de informática acessível;

- $\quad$ Material em formato impresso em caráter ampliado.

No entanto, este percentual é somente declarado pelos cursos, que afirmam dispor de todos os recursos acima. Não existe nenhuma comprovação por parte do INEP quanto á veracidade deste percentual e principalmente quanto á qualidade destes recursos. Na literatura pesquisada foi possível encontrar trabalhos onde constam entrevistas com alunos deficientes que trazem evidências das universidades não estarem preparadas para atender aos alunos com deficiência: “necessidades de adaptações arquitetônicas” (Maiola, Boos \& Fischer, 2008, p. 91), boa parte de nossos professores universitários não possui uma formação consistente nesta área (Moreira, 2008, p. 13), “os resultados encontrados convergem para o despreparo, tanto da Universidade, quanto dos profissionais que dela fazem parte, para proporcionar o atendimento adequado às necessidades especiais desses alunos” (Rocha \& Miranda, 2009, p.197) e muito ainda existe para ser realizado (Fortes, 2005, p.9).

Outro ponto a ser considerado é a Portaria 3.284 de 2003 do MEC que estabelece critérios mínimos de acessibilidade às instituições de ensino superior para autorizar e reconhecer cursos e credenciar novas instituições. O alto percentual observado acima de instituições aptas não seria uma forma de cumprir a exigência da Portaria somente para efeitos de liberação para funcionamento? Esta é somente uma hipótese a qual não será aprofundada neste trabalho.

O Programa Universidade para Todos (PROUNI) do Ministério da Educação, criado pelo Governo Federal em 2004, regula a atuação de entidades beneficentes de assistência social no ensino superior (Lei $n^{0}$. 11.096 de 2005) e oferece bolsas de estudos em instituições de educação superior privadas, em cursos de graduação para estudantes brasileiros que não tenham um diploma de graduação. O programa também conta com bolsas específicas para os deficientes declarados, a fim de incentivar o ingresso das pessoas com deficiência nas universidades. $\mathrm{O}$ Artigo $3^{\circ}$ dispõe sobre quem pode se inscrever no Programa:

“Somente poderão se inscrever no processo seletivo do PROUNI, referente ao primeiro semestre de 2012, os brasileiros não portadores de diploma de 
curso superior que tenham participado do Enem referente ao ano de 2011 e que atendam a pelo menos uma das condições a seguir:

I - tenham cursado o ensino médio completo em escola da rede pública; II tenham cursado o ensino médio completo em instituição privada, na condição de bolsista integral da respectiva instituição; III - tenham cursado todo o ensino médio parcialmente em escola da rede pública e parcialmente em instituição privada, na condição de bolsista integral na instituição privada; IV - sejam ‘portadores de deficiência’; V - sejam professores da rede pública de ensino, no efetivo exercício do magistério da educação básica e integrando o quadro de pessoal permanente da instituição pública, conforme disposto no art. 3o do Decreto no. 5.493/2005. É necessária a comprovação da condição de deficiente com laudo médico atestando a espécie e o grau da deficiência, com expressa referência ao código correspondente da Classificação Internacional de Doença (CID), quando for o caso.” (Portaria Normativa no1 de 6 de Janeiro de 2012)

Mesmo com o incentivo do programa, em 2012 existiam 7.177 alunos bolsistas com deficiência representando somente 1\% das 1,1 milhão de bolsas concedidas (PROUNI).

No âmbito da cidade de São Paulo, foi criado pela Lei Municipal 15.096 de 05/10/2010, o Censo Inclusão. Em dezembro de 2012, a Secretaria Municipal da Pessoa com Deficiência divulgou os dados preliminares deste censo, o primeiro na história do município de São Paulo. Os resultados foram obtidos a partir dos formulários respondidos por pessoas com deficiência ou mobilidade reduzida, no período entre março e agosto de 2012, por formulário impresso e pela internet.

2.759.004 pessoas declararam ter alguma deficiência na cidade de São Paulo, destas ${ }^{4}$ :

- População residente com deficiência visual - 2.274.466 pessoas;

- $\quad$ População residente com deficiência auditiva - 516.663 pessoas;

- $\quad$ População residente com deficiência motora - 674.409 pessoas;

- $\quad$ População residente com deficiência mental/intelectual - 127.549 pessoas.

Em relação à Educação, o panorama da cidade de São Paulo está abaixo, incluindo a distribuição geográfica:

\footnotetext{
${ }^{4}$ As pessoas com mais de uma deficiência foram contadas em todas as citadas.
} 
- $\quad$ Frequentam escola ou faculdade: 7.393 pessoas;

- $\quad$ Possuem o ensino fundamental completo: 1.886 pessoas;

- $\quad$ Possuem o ensino médio completo: 2.487 pessoas;

- $\quad$ Possuem curso profissionalizante completo: 1.162 pessoas;

- $\quad$ Possuem educação superior completo: 3.167 pessoas;

- $\quad$ Possuem Pós-Graduação completa: 2.040 pessoas. 


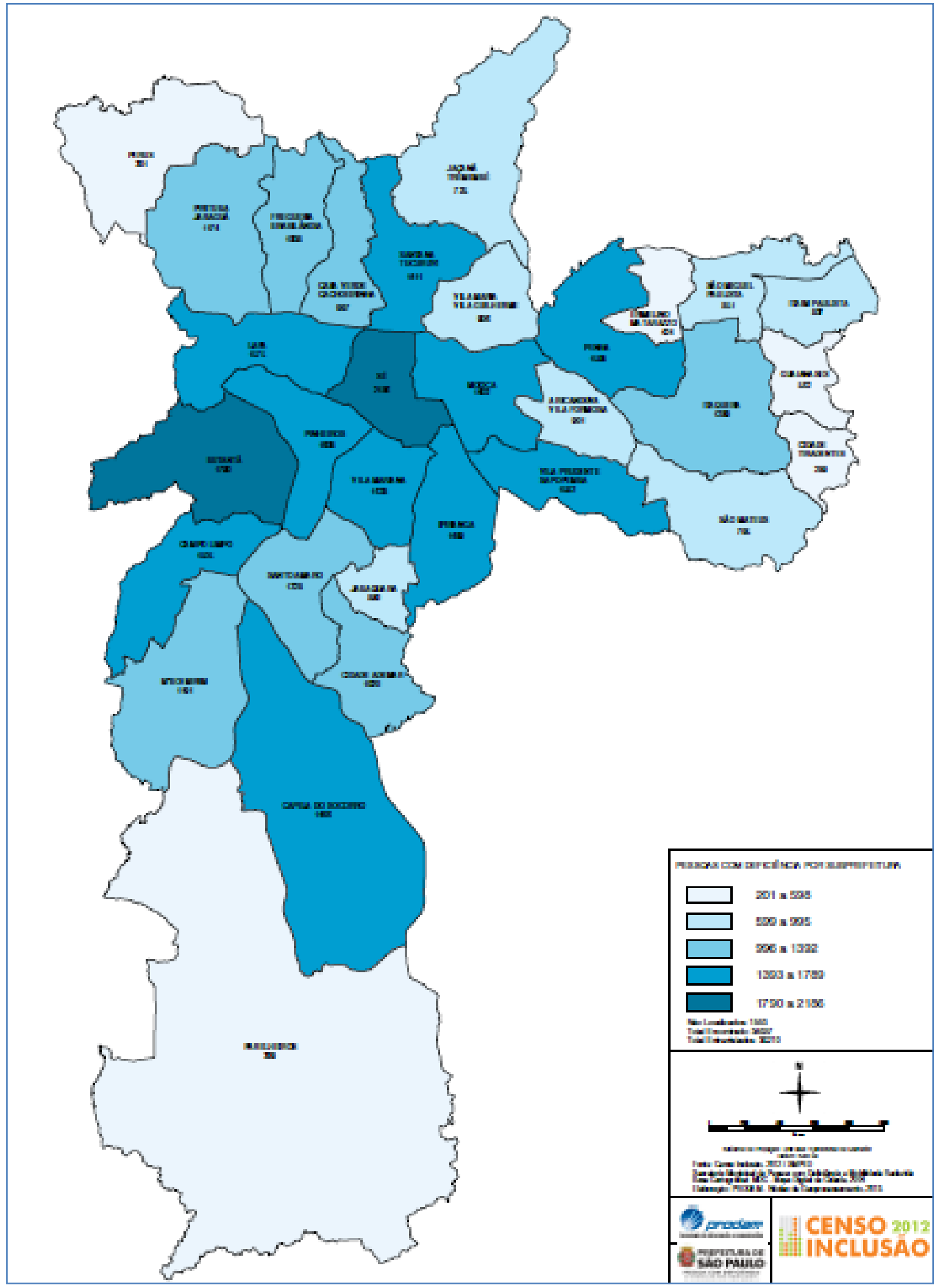

Figura 12. Distribuição Geográfica de Pessoas com Deficiência na cidade de São Paulo (Prefeitura de São Paulo, 2012).

Apesar de poucos dados a respeito da educação, o Censo Inclusão não deixa de ser pioneiro na tentativa de medição regional. 
Fato é que a presença de pessoas com necessidades educacionais especiais no ensino superior é um novo desafio. O processo de construção de um espaço inclusivo na educação, qualquer que seja seu o nível, não se dá por meio de uma padronização; ao contrário, é necessário que a inclusão se faça a partir da experiência e do reconhecimento das diferenças. (Ferrari \& Sekkel 2007)

A partir do próximo capítulo será abordada a Metodologia utilizada neste trabalho. 


\title{
3 Metodologia
}

Este item evidenciará a trajetória percorrida pelo pesquisador para realizar o trabalho, possibilitando a replicação para outros estudos e também a verificação da consistência do trabalho.

Existem duas categorias de metodologia científica: quantitativa e qualitativa. A metodologia quantitativa foca na análise numérica tanto da amostra quanto de seus resultados através de ferramentas estatísticas. Enquanto que a metodologia qualitativa revela a forte influencia positivista de aplicar modelos das ciências naturais às ciências sociais, limitando o fenômeno ao observável e com ênfase ao dado empírico. (Silva, 2007)

Do ponto de vista metodológico, esta pesquisa pode ser classificada como qualitativa, para cuja realização ocorreu um levantamento de literatura e pesquisa de campo, visto que por meio da história oral, buscou-se apurar a trajetória de alunos com deficiência no acesso e permanência nas instituições superiores de ensino além de rever todos os direitos adquiridos ao longo da história.

\begin{abstract}
A pesquisa qualitativa preocupa-se com uma realidade que não pode ser quantificada, respondendo a questões muito particulares, trabalhando um universo de significados, crenças, valores e que correspondem a um espaço mais profundo das relações, dos fenômenos que não podem ser reduzidos à operacionalização de variáveis. A História oral é uma das modalidades de estudo da pesquisa qualitativa. Na História oral o que interessa ao pesquisador é o ponto de vista do sujeito. O objetivo desse tipo de estudo é justamente apreender e compreender a vida conforme ela é relatada e interpretada pelo próprio autor. (Spindola, 2003)
\end{abstract}

Através do método de História Oral será possível conhecer a trajetória dos alunos com deficiência que cursaram uma universidade, ressaltando seus obstáculos enfrentados e facilitadores encontrados, e apontando melhorias necessárias para o atendimento deste público, através de sugestões dos próprios alunos com deficiência.

“o objetivo é conduzir a pessoa estudada a campos significativos de sua experiência pessoal, os quais são capazes de envolvê-la no sentido subjetivo dos diferentes espaços delimitadores de sua subjetividade individual. A partir desses espaços, o relato expressa, de forma crescente, seu mundo, suas necessidades, seus conflitos e suas reflexões, processo esse que envolve emoções que, por sua vez, facilitam o surgimento de novos processos 
simbólicos e de novas emoções, levando à trama de sentidos subjetivos.” (Rey, 2010, p. 126)

\subsection{A Universidade de São Paulo}

Dento da cidade de São Paulo, está localizada a Universidade de São Paulo. Fundada em 25 de janeiro de 1934, na mesma data do aniversário da cidade, surgiu da união das Faculdades de Direito, Medicina, Farmácia e Odontologia, Filosofia, Ciências e Letras e Escola Politécnica e Superior de Agricultura Luiz de Queiroz. As seis instituições de ensino superior já existiam, mas se uniram para formar a pedra fundamental da USP. A Universidade veio com o lema Scientia Vinces (Vencerás pela Ciência, em latim). Atualmente a USP é referência nacional e internacional. Tratando-se de produção científica, 22\% da produção nacional estão concentrados na USP; ao observar dados mundiais, o Brasil representa 2\% da produção científica, portanto pode-se afirmar que a USP representa $0,5 \%$ da produção mundial. (Memória Universidade de São Paulo, 2013). Além da produção científica, grandes nomes no Brasil passaram pela universidade: na instituição se formaram no ensino superior doze dos quarenta e dois presidentes brasileiros, como o sociólogo Fernando Henrique Cardoso e o advogado Jânio Quadros, este último e outros dez apenas na Faculdade de Direito, que também formou 53 ministros na história do Supremo Tribunal Federal (STF).

A USP é uma das três universidades públicas mantidas pelo governo do estado brasileiro de São Paulo, junto com a Universidade Estadual de Campinas (UNICAMP) e a Universidade Estadual Paulista (UNESP). É a maior universidade pública brasileira e a universidade mais importante do país em termos de produção científica, conforme dados mencionados anteriormente e uma das melhores e mais prestigiadas do mundo.

Conta com cerca de 86 mil alunos, distribuídos em 58 mil nos cursos de graduação e 28 mil na pós graduação. Na graduação são 249 cursos enquanto que na pós graduação são 239 programas, dos quais fazem parte 332 cursos de mestrado e 309 de doutorado; todos cursos dados nas 42 unidades de ensino e pesquisa por cerca de 6 mil professores. É composta por 12 campus, sendo 4 em São Paulo e os demais distribuídos nas cidades de Bauru, Lorena, Piracicaba, Pirassununga, Ribeirão Preto e dois em São Carlos. O principal deles, concentrado em São Paulo, é chamado de Cidade Universitária Armando de Salles Oliveira. Com uma área de $7443770 \mathrm{~m}^{2}$, anteriormente fora ocupado pela Fazenda Butantã e na década de 30 foi 
reservado para a Universidade São Paulo. A partir de 1960 as unidades começaram a se transferir para a Cidade Universitária. A Reitoria, órgão executivo central da administração superior encontra-se na Cidade Universitária.

Mais recentemente, em 2005, foi construído na Zona Leste de São Paulo o campus USP Leste, que atualmente abriga a Escola de Artes, Ciências e Humanidades (EACH), tendo alguns cursos que fogem à tradição universitária brasileira e visam à diversificação das áreas consolidadas da instituição. A Universidade de São Paulo possui 70 bibliotecas em suas unidades de ensino, museus e institutos de pesquisa nos diversos campis, que somadas ao Departamento Técnico do Sistema Integrado de Bibliotecas da Universidade de São Paulo (SIBiUSP), órgão da reitoria, compõem o Sistema Integrado de Bibliotecas da USP. O acervo completo da Universidade de São Paulo pode ser consultado pelo Portal de Busca Integrada, que permite tanto o acesso aos materiais online que a USP dispõe quanto provê a localização e informações dos itens físicos que se encontram nas bibliotecas. Algumas bibliotecas especializadas também podem ser consultadas online, como a Biblioteca de Teses e Dissertações da USP e o Portal de Revistas da USP. A Biblioteca da Produção Intelectual da USP é o repositório da Universidade, contribuindo para tornar pública e acessível a produção realizada internamente. No Portal do SIBiUSP é possível encontrar informações sobre todas as bibliotecas das unidades e também sobre os diversos recursos online disponíveis para a comunidade USP e o público em geral.

A forma de acesso para a instituição é o concurso vestibular, feito anualmente pela Fundação Universitária para o Vestibular (FUVEST). Realizado em duas etapas eliminatórias, consiste de um teste de múltipla escolha na primeira fase e prova discursivas na segunda fase.

\subsection{A Faculdade de Economia Administração e Contabilidade (FEA)}

Dentro da USP, encontra-se a Faculdade de Economia, Administração e Contabilidade da Universidade de São Paulo. As entrevistas realizadas neste trabalho, terão como ponto em comum, ex alunos e alunos da FEA.

Fundada em 1946, localizava-se na Vila Buarque, Centro de São Paulo, com o nome de Faculdade de Ciências Econômicas e Administrativas (FCEA). Os dois cursos iniciais da Faculdade eram o de Ciências Econômicas e o de Ciências Contábeis e Atuariais. Uma reforma estrutural interna, em 1964, reorganizou a Faculdade em cinco graduações distintas: 
Ciências Econômicas, Ciências Contábeis, Ciências Atuariais, Administração de Empresas e Administração Pública. Em 1969, a Reforma Estrutural da USP mudou o nome de FCEA para Faculdade de Economia e Administração e surgiu a divisão dos departamentos em Economia, Administração e Contabilidade. Em 1971, a FEA foi transferida para a Cidade Universitária.

A FEA USP é uma instituição pública de ensino e pesquisa, mundialmente reconhecida pela excelência de sua produção acadêmica e de seus cursos, tanto de graduação quanto pósgraduação. Com mais de 60 anos de existência, a Faculdade de Economia, Administração e Contabilidade da Universidade de São Paulo surgiu com o objetivo de preparar profissionais de administração, economia e contabilidade para suprir as necessidades dos grandes centros do Brasil, que na época acabava de sair da segunda Guerra Mundial e passava por um processo de democratização da economia. Seu objetivo inicial, que permanece até hoje, é a formação de profissionais que contribuam e façam a diferença na sociedade de maneira positiva. Décadas após sua criação, a FEA é referência nacional e internacional nas áreas que abrange. Nivelando suas atividades pelos altos padrões da Universidade de São Paulo e aliando o conhecimento sobre a realidade brasileira com os referenciais e conhecimentos metodológicos das mais renomadas instituições internacionais, a faculdade é destaque entre as demais na formação de economistas, administradores e especialistas em contabilidade e atuária (FEA, 2014).

A FEA USP conta com diversos órgãos de relevância na representação discente, pesquisa e extensão acadêmica: o Centro Acadêmico Visconde de Cairu (CAVC), fundado em 1956; a Fundação Instituto de Pesquisas Econômicas (FIPE), em 1973; a Fundação Instituto de Pesquisas Contábeis, Atuariais e Financeiras (FIPECAFI), em 1974; a Fundação Instituto de Administração (FIA), em 1980; a Comissão de Cooperação Internacional (CCInt), em 1986; e o Cursinho da FEA, em 2000.

Atualmente, são quatro os cursos de graduação da FEA USP: Administração de Empresas, Ciências Econômicas, Ciências Contábeis e Atuária, sendo que o último é cursado somente no período noturno, e os outros, nos períodos diurno e noturno. A Faculdade também oferece os cursos de pós-graduação em Economia, implantado em 1966, Administração e Ciências Contábeis, ambos criados em 1970.

\subsection{O USP Legal}


Os obstáculos que as pessoas com deficiência têm que enfrentar na Universidade não se restringem somente ao aspecto físico - como a ausência de rampas e elevadores. Eles envolvem também questões pedagógicas e atitudinais indispensáveis para o exercício de seus direitos que, embora garantidos por lei, ainda são pouco observados. Com essa preocupação, a USP criou em 2001 uma Comissão Permanente conhecida como Programa USP Legal, iniciativa pioneira que acompanhou um momento histórico de luta pelo direito das pessoas com deficiência. Atualmente o Programa integra o Núcleo dos Direitos da Pró-Reitoria de Cultura e Extensão Universitária. O USP Legal trabalha no estabelecimento de políticas e ações para assegurar que os espaços, equipamentos e procedimentos na Universidade sejam acessíveis aos alunos, servidores e docentes com deficiência em todos os campus. (USP Legal, 2010)

Segundo dados obtidos do site do USP Legal, existem aproximadamente 200 alunos com deficiência matriculados em cursos de graduação. É possível que o número seja maior, devido a existência de pessoas que escolhem não declarar sua deficiência, seja por receio da discriminação como também por já conviverem bem com a deficiência e não necessitarem de apoio complementar. Estes dados não consideram a pós-graduação e a extensão (que não estão quantificados), além do público externo que frequenta os diversos espaços e serviços da USP, como o Hospital Universitário (HU).

Ao se matricular na USP, o aluno pode declarar se tem alguma deficiência ou necessidade educacional especial através do USP Legal. Com esta informação, é possível, entre outras medidas, direcionar recursos para a adequação do espaço físico que este estudante irá frequentar. Nesse caso, o trabalho do USP Legal é, fundamentalmente, de mediação entre a demanda identificada e os responsáveis por responder a elas, já que o Programa não executa as obras em si. Outra ação que o USP Legal realiza é a orientação da unidade e seus docentes sobre como lidar com as diversas situações que envolvem a vida acadêmica e fazer um acompanhamento do aluno, de acordo com suas necessidades. Uma pessoa com baixa visão, por exemplo, não consegue enxergar a lousa se o professor escreve com uma letra muito pequena ou com uma cor de giz de pouco contraste. (USP Legal, 2010)

Segundo informações do site da USP Legal, está sendo desenvolvido um sistema de informação onde serão cadastrados todos os equipamentos urbanos de acessibilidade na universidade. Ele estará integrado ao Sistema Atlas, banco de dados com as características do espaço físico da USP, como salas, rede de esgoto, placas, cestos de lixo e sistemas de 
iluminação a fim de melhorar ainda mais a permanência do aluno com deficiência dentro da universidade.

\subsection{Participantes da Pesquisa}

A pretensão inicial de público para os relatos desta pesquisa eram alunos cursando, que tentaram cursar ou concluintes do ensino superior em contabilidade. Para tanto, a autora buscou em diversos órgãos desta categoria informações a respeito destes profissionais, porém não obteve êxito. Tentativas junto ao Conselho Federal de Contabilidade (CFC), a FUVEST e ao Programa de Inclusão da Universidade de São Paulo (INCLUSP) foram feitas diversas vezes, de forma documentada por email, porém todas tiveram respostas negativas ou nem receberam resposta. Dada a restrição de público existente neste contexto, optou-se por estreitar o escopo e fazer um levantamento com pessoas que cursam ou que concluíram alguma disciplina relacionada a Contabilidade na Faculdade de Economia, Administração e Contabilidade da Universidade de São Paulo. Novo desafio foi encontrado nesta escolha, visto que a faculdade não mantém um banco de dados de (ex) alunos com deficiência; não existe essa marcação no cadastro do aluno ou candidato. A secretaria da Graduação e da Pós Graduação foram consultadas, porém não foi possível obter nenhum contato através destas seções.

Desta forma, para tornar o trabalho viável, foram entrevistados alunos com deficiência graduados e com alguma passagem pela contabilidade, seja através da faculdade ou através do ambiente profissional. Através de indicações de professores e alunos da instituição, foi possível encontrar estes alunos; obtendo ao final seis entrevistas ao término deste trabalho.

\subsection{Pesquisa de campo}

As entrevistas junto aos alunos com deficiência que compõem este trabalho ocorreram nos anos de 2014 e 2015. Foram realizadas de acordo com a disponibilidade dos participantes, através de videoconferência ou pessoalmente, sempre com o prévio consentimento dos participantes por escrito. 
Os nomes dos entrevistados foram mantidos em confidencialidade, a fim de que não ocorra exposição da pessoa, conforme termo de consentimento assinado pelos mesmos. A menção aos alunos será feita como Aluno A, Aluno B, Aluno C, Aluno D, Aluno E e Aluno F; conforme ordem cronológica das entrevistas.

No processo de busca por alunos com deficiência com alguma ligação com a FEA, foi apontado por professores, funcionários e colegas o Aluno G. Este aluno possui deficiência visual e concluiu sua graduação em contabilidade em 1999. Em consulta ao Departamento de Contabilidade foi obtido o email e telefones para contato com este aluno. Foram feitas diversas tentativas de contato por email e telefone com este aluno, porém não foi possível estabelecer comunicação com o mesmo, provavelmente pelos dados estarem desatualizados. Sendo assim, não foi possível entrevistar o aluno G.

Dentre os alunos entrevistados, o aluno A é do sexo masculino, possui deficiência visual e perdeu a visão na adolescência por síndrome de glaucoma. A autora conseguiu contato com ele através da indicação de uma professora. Foram realizadas duas entrevistas pessoalmente com o aluno A, a primeira em seu local de trabalho, uma faculdade na cidade de São Paulo e a segunda em sua residência.

O aluno B também é do sexo masculino, possui deficiência auditiva. Ficou surdo aos 3 anos e piorou há 4 anos, quando completou 26 anos, perdendo a audição dos dois ouvidos. Há dois anos realizou um implante. Assim como o aluno A, a autora conseguiu seu contato através da mesma professora. Foram realizadas duas entrevistas com este aluno, através de mensagem instantânea, pelo fato do aluno residir em outro estado.

A aluna C é do sexo feminino, possui deficiência visual (visão subnormal e ceratocone). A aluna C estudou com a autora em uma disciplina na FEA como aluna especial no ano de 2012. Pela proximidade entre ambas, foi solicitado que a aluna $\mathrm{C}$ participasse desta pesquisa. As duas entrevistas realizadas ocorreram por videoconferência, pelo fato da aluna C ter-se mudado para Belo Horizonte por questões profissionais.

O aluno D é do sexo masculino, possui deficiência visual somente na vista direita, com perda de 95\% da capacidade de enxergar. A autora conseguiu contato com o aluno através da indicação da aluna C que trabalhava com o aluno D. A entrevista ocorreu pelo telefone em comum acordo entre entrevistado e entrevistadora. 
O aluno E é do sexo masculino, possui deficiência física classificada como paraplegia. A deficiência surgiu devido a um acidente que sofreu em 2011 quando praticava o esporte de trilhas em motos. Devido a quebra de duas vértebras, ocorreu a lesão medular. O contato com o aluno foi intermediado através de um professor. A entrevista ocorreu via videoconferência.

A aluna F é do sexo feminino, possui deficiência física classificada como distrofia muscular. Aos 9 anos de idade começou a ter dificuldades para andar e após 3 anos chegou-se no diagnóstico de distrofia, através de um exame de DNA. O contato com a aluna foi possível através da empresa onde a pesquisadora trabalha. A entrevista ocorreu pessoalmente.

Todas as nove entrevistas com os seis entrevistados foram conduzidas, gravadas e transcritas pela autora. Todas as entrevistas na íntegra estão de posse da autora e as questões que nortearam os relatos estão no apêndice deste trabalho.

Além das entrevistas com os seis estudantes, foram realizadas entrevistas com uma aluna da pós graduação da Escola Politécnica da USP (POLI) e com a coordenadora da biblioteca da FEA USP para efeito de pré teste. A entrevista da aluna foi fundamental para o desenho final da metodologia.

A aluna da POLI é do sexo feminino, tem 32 anos, possui graduação em engenharia ambiental na POLI USP de 2006 a 2010 e atualmente cursa mestrado em Engenharia Civil. Trabalha na Fundação Centro Tecnológico da Hidráulica desde 2008. Sua deficiência é a paraplegia.

A biblioteca da FEA passou por uma reforma que teve início em 2011, onde uma das principais preocupações foi garantir acesso à biblioteca aos alunos com deficiência, tais como mobiliário exclusivo, elevadores e espaço adequado entre as estantes para cadeirantes, sinalização por toda a biblioteca para deficientes auditivos, sala com recursos para deficientes, funcionários com noções básicas de libras, coordenadores designados para acompanhar o projeto. 


\section{Resultados}

Após a realização das entrevistas, um procedimento importante na análise foi a elaboração das categorias, ou seja, a criação de indicadores que fundamentem a interpretação final. De acordo com Bardin (1977, p.117), a “categorização é uma operação de classificação de elementos constitutivos de um conjunto, por diferenciação e, seguidamente, por reagrupamento segundo o gênero (analogia), com os critérios previamente definidos”. A categorização é uma forma de esquematização onde é possível correlacionar classes de acontecimentos a fim de ordená-los, transformando dados brutos em dados organizados.

Encerrada a transcrição e análise das entrevistas, foram propostas quatro categorias:

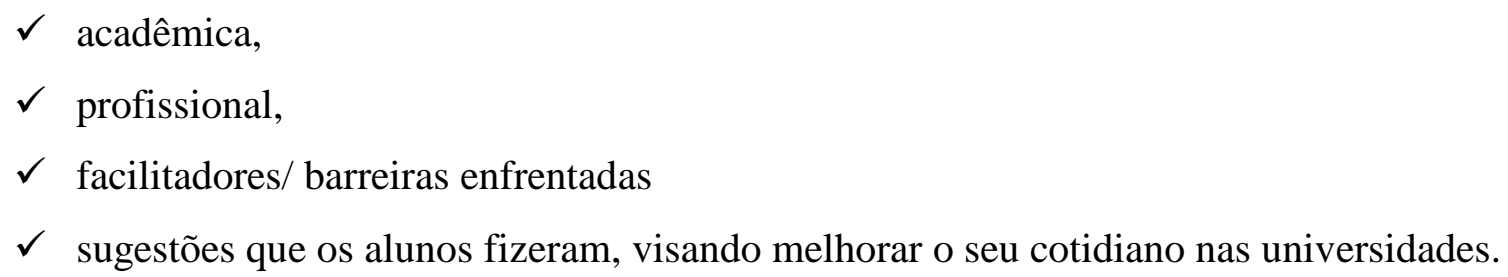

\subsection{Eixo Acadêmico}

Ao analisar o primeiro eixo sobre a trajetória acadêmica, percebe-se perfis distintos entre os seis estudantes. Dois estudantes têm carreira na área acadêmica enquanto os outros quatro possuem carreira em empresas privadas.

O aluno A está cursando pós doutorado em História na Faculdade de Filosofia, Letras e Ciências Humanas da USP (FFLCH), tem doutorado em Economia no exterior pela Columbia University e foi aluno especial da FEA em 2011 em duas matérias: Controladoria e Análise de Custos. Sua graduação foi concluída no ano de 1980 em Economia Regional e Urbana na Faculdade São Luis. Ao comparar o ensino no Brasil com o ensino no exterior, afirma que a base matemática que teve na Faculdade São Luis o ajudou muito no outro país e que não considera o ensino lá fora tão superior quanto ao brasileiro, devido a sua formação sólida na graduação. 
O aluno B está cursando doutorado em Administração na Universidade Federal de Santa Catarina (UFSC), possui mestrado e graduação na mesma instituição, no mesmo curso. Ao ser indagado sobre o motivo da escolha do curso afirma que foi decidido de forma impulsiva:

\footnotetext{
Aluno B: foi uma escolha meio impulsiva, eu tinha 16 anos, não sabia direito nem amarrar os cadarços... achava que gostaria de trabalhar em uma empresa, como gerente, algo assim, estava em dúvida entre fazer Engenharia de Produção e Administração, optei por Administração porque não gostava de matemática.... talvez eu não tenha feito Direito por me sentir inseguro em uma profissão que dependesse tanto da fala e da audição, com certeza a deficiência afeta nossas escolhas de maneira que nem percebemos...
}

Em 2011 veio para São Paulo assistir matérias como aluno especial na FEA em busca de outras disciplinas. Cursou Análise de Balanços, Modelos Multivariados Aplicados e Teoria da Contabilidade enquanto aluno especial. Procurou pelas matérias relacionadas a Contabilidade devido ao interesse por estatística.

A aluna C cursou o ensino fundamental e técnico em contabilidade em escolas públicas, iniciou a faculdade de Análise de Sistemas na Universidade Bandeirantes e por dois anos permaneceu nela, desistindo da mesma por falta de interesse. Em seguida, iniciou a graduação em Contabilidade e se formou já adentrando profissionalmente na área. Quanto a decisão de ingressar no curso de Contabilidade afirma que desejava ter uma profissão e via no contador essa possibilidade. Além disto, tinha familiaridade com matemática. Foi aluna especial da FEA em 2012, onde cursou a matéria de Controladoria junto com a autora deste trabalho e também assistiu aulas no Instituto de Matemática e Estatística (IME). Tinha planos para adentrar no mestrado em Contabilidade na FEA, porém por questões de mudança profissional, resolveu cancelar este projeto e recentemente mudou-se para Belo Horizonte devido ao trabalho.

O aluno D possui graduação em Administração e pós graduação em Gestão de Negócios na Universidade Presbiteriana Mackenzie. Na época da graduação prestou vestibular para adentrar na FEA, através do exame da FUVEST, porém não foi aprovado e decidiu seguir seus estudos em uma universidade particular. Além disto, morou dois anos na Irlanda e Londres. Em 2013 assistiu aula na FEA como aluno especial em Teoria da Contabilidade. Decidiu adiar a decisão de cursar um mestrado pois está se mudando para a Irlanda novamente com a família. 
O aluno E possui graduação em Administração pela FEA e optou pela profissão devido ao interesse pela área de Negócios.

A aluna F iniciou sua graduação em Geografia, no estado da Bahia, porém no segundo ano, mudou de curso e de estado, vindo para São Paulo estudar Administração através de uma bolsa integral concedida pelo PROUNI. Inicialmente optou por cursar Geografia visando prestar um concurso público no estado da Bahia, ao se mudar para São Paulo, vislumbrou no curso de Administração de Empresas uma oportunidade de carreira.

Todos os alunos completaram seus estudos no tempo previsto, tanto o Ensino Fundamental, o Médio e o Superior. Nenhum deles necessitou de mais tempo por conta da deficiência. Todos atribuem sua entrada na faculdade por mérito próprio, por serem bons alunos. É possível identificar nos dizeres dos alunos entrevistados que todos assumiram o controle de suas vidas, indo em busca de oportunidades e direitos reservados á eles. Não foi percebido em nenhum momento o papel de vítima nestes indivíduos devido a sua deficiência. Isso é constatado nos dizeres da aluna F:

\begin{abstract}
Aluno F: "tinha duas opções: ou eu enfrentava e encarava a deficiência ou me entregava. Não é fácil encarar as pessoas. Tem que ter muita força de vontade pra conseguir fazer as coisas. É mais fácil se entregar do que enfrentar todos os obstáculos.”
\end{abstract}

Foi possível constatar que dos seis entrevistados, cinco deles estudaram em escola particular tanto no Ensino Fundamental quanto no Médio. Não é possível afirmar que o estudo em escola particular anterior a entrada no ensino superior permite mais condições de acesso e permanência na universidade, no entanto, esta questão também é levantada por Rocha e Miranda (2009) em outro estudo sobre o tema:

\footnotetext{
"O fato de existir, a maioria de alunos oriundos de escola privada, um total de doze, demonstrou claramente que, o acesso da pessoa com deficiência na universidade pública é fundamentalmente demarcado pela condição sócioeconômica. Aqueles que possuem escolarização em boas instituições privadas, com apoio pedagógico e financeiro para aquisição de tecnologias de ajuda e infra-estrutura de transporte particular, assim como, outros serviços de profissionais como fisioterapeuta, fonoaudióloga, por exemplo, têm mais condição de acesso ao ensino superior público.” (p. 204)
} 


\subsection{Eixo Profissional}

No eixo sobre profissão, o aluno A até o ano passado, era professor em uma faculdade na cidade de São Paulo e coordenava um curso voltado para deficientes visuais na mesma instituição. No entanto, a faculdade passou por reestruturação salarial e dispensou o aluno A. Além de professor, o aluno A possui uma consultoria de custos agrícolas desde 1981. Após estudar nos Estados Unidos o aluno voltou para o Brasil e buscou um emprego, porém não encontrou um cargo compatível com seus desejos e optou por abrir uma empresa:

\footnotetext{
Aluno A: "Depois fui para os Estados Unidos e voltei para a mesma empresa; que ficou pequena para minha atuação, os donos eram velhos e não pensavam em carreira. Eu pensava que com toda minha qualificação, falando quatro línguas seria mais fácil conseguir um bom emprego e não foi, a discriminação era exatamente igual. Daí resolvi abrir uma empresa, contando com a ajuda financeira da minha esposa. A partir daí a discriminação foi embora, pois passei a ser patrão e não mais empregado. O empreendedor assume riscos. Nunca tive dificuldades, exceto na época do confisco Collor, onde fiquei sem receber nada durante um grande período. $\mathrm{E}$ as pessoas me perguntavam porque não procurava emprego, e decidi não mais ser funcionário. Não tem nada pior do que ser empregado, hoje tenho 28 clientes, então preciso ser mandado embora por 28 ao invés de 1 quando você é empregado. E quanto mais o tempo passa, torna-se pior. Você fica caro e velho. O que consegui na vida, foi por qualificação e sorte. Se eu tive competência, foi para não jogar fora as oportunidades”
}

Quanto a lei de cotas trabalhistas, julga-se contra. Acredita que no momento em que se cria a legislação, cria-se também cargos para deficientes; tirando da pessoa a oportunidade de ascender na empresa. Tem um amigo deficiente que foi promovido a gerente e os colegas de trabalho criticaram a promoção de um funcionário oriundo de cotas. Acredita em um modelo de cotas de acordo com a habilidade da pessoa. Por exemplo, um deficiente auditivo não é deficiente para um cargo de desenhista; portanto, não deveria usufruir da cota. A caracterização de uma pessoa com deficiência é muito complexa e a cota generaliza a deficiência. Entende que há pessoas que não tem necessidades especiais e mesmo assim, 
busca a classificação de deficientes somente para adentrar nos percentuais de cotas nas empresas.

Quanto aos deficientes visuais trabalhando com Contabilidade, pensa que há muitos poucos, dado ser uma matéria muito abstrata. Uma vez tentou fazer um balancete em braile e desistiu; não há ferramentas contábeis para deficientes visuais.

O aluno B começou ajudando o pai em um negócio próprio, na sequência, realizou um estágio na secretaria da pós graduação onde se formou e em 2013 prestou concurso para professor na Universidade Federal Fronteira do Sul (UFFS), sendo aprovado e atualmente ministra aulas nesta universidade. Diz se sentir mais protegido no serviço público do que no privado. Ao ser indagado se a área de negócios poderia contribuir com a inclusão, afirma que enxerga oportunidades em empreendedorismo social, economia solidária; há oportunidades dentro de uma lógica inclusiva. No entanto, em cidades pequenas como a dele, não vê as empresas preocupadas com a diversidade. Relata que a era do capital intelectual ainda não chegou em todos os lugares do Brasil.

A aluna C trabalhou em uma concessionária de energia por quinze anos e depois mudou para a empresa atual do ramo de consultoria contábil. A primeira empresa trazia estabilidade de emprego, porém não via oportunidade para crescer na carreira; por este motivo, procurou uma nova oportunidade na empresa atual. Afirma ter tido muitas dificuldades para levar os conceitos de contabilidade vistos em sala para a prática do trabalho nas duas empresas. Quanto a dificuldades devido sua deficiência, não sinaliza nenhum, pelo contrário, a empresa proporciona ferramentas para minimizar as dificuldades do dia a dia, como por exemplo, um monitor de 24 polegadas. Acredito que o fato de ter a deficiência visual desenvolveu uma habilidade maior na checagem das contas, fazendo seu trabalho de forma bastante precisa.

Quanto indagada a respeito das cotas trabalhistas, considera-se a favor. Entende a cota como uma forma de incentivar as pessoas com deficiência a serem inseridas no mercado de trabalho. Gostaria que as pessoas com deficiência fossem contratadas por mérito, porém enquanto isso não ocorre, a lei está instaurada para proporcionar oportunidades a elas. Acredita que o funcionário com deficiência não deve fazer papel de vítima nem receio de trabalhar e sim, mostrar seu potencial e contribuir com ideias. 
O aluno D trabalhou em diversas empresas do setor financeiro e atualmente atua na mesma empresa que a aluna C, porém efetuará seu desligamento em breve devido a decisão de mudar de país. Acredita que encontrará condições melhores em outro país do que no Brasil.

O aluno E trabalhou no mercado financeiro e pediu demissão dias antes do acidente que o deixou com a deficiência física, o intuito era realizar um estágio na Alemanha; plano este cancelado devido ao acidente. Atualmente atua como consultor, comprando e vendendo ações na Bolsa de Valores de São Paulo. Possui parceria com alguns escritórios de gestão de patrimônio em São Paulo. Até o momento, não teve dificuldades para realizar reuniões em clientes, devido existir rampas e elevadores nos prédios; porém sua maior dificuldade está na locomoção em vias públicas. Devido a dificuldade de locomoção em vias públicas, almoça diariamente em sua casa, de onde trabalha e isso gera uma vantagem competitivas em relação aos demais consultores que fazem uma pausa para almoçar e ás vezes, perdem oportunidade de compra e venda de ações neste período. Futuramente, pretende concorrer a um concurso público em Brasília pelo Tribunal de Contas da União, porém mesmo aprovado no concurso, tem intenção de continuar trabalhando como consultor de compra e venda de ações paralelamente.

Quando questionado sobre as cotas, acha justo a lei existir. Acredita que com isso, existe o incentivo para as pessoas com deficiência a serem reintegradas no mercado de trabalho; porém acha mais difícil o percentual máximo de 5\% ser cumprido no setor de escritórios; devido a qualificação exigida em alguns cargos. Afirma que uma pessoa com deficiência leva mais tempo para conseguir fazer algo do que as pessoas sem deficiência, daí a necessidade da proteção legal ser justa.

A aluna F iniciou sua carreira em 2008 em um banco em São Paulo trabalhando inicialmente em agência bancária e posteriormente na área de faturamento. Na área de faturamento, tinha uma função que exigia muita atenção, a fim de não lançar despesas em contas contábeis erradas, porém não existia nenhum reconhecimento da área em relação ao seu trabalho. Atualmente trabalha em outra área do banco, com Segurança Predial e sente-se mais satisfeita na função, porém afirma existir muito desconhecimento por parte dos gestores a respeito de como lidar com um funcionário com deficiência:

Aluna F: "Existe falta de informação nas empresas. Todos os gestores que tive, senti preconceito. Eles têm ideia do que seja uma deficiência e tratam a pessoa com deficiência com a ideia que eles têm. A partir do momento que 
me deram mais espaço, perceberam que eu poderia fazer mais. Me davam atividades que não tinham tanto valor; me subestimavam. Foi assim na agência bancária, na área atual... Tive que trabalhar muito mais que os outros para mostrar minha competência. Há pessoas com deficiência que se escoram nas cotas, mas não sou assim. Assim como há pessoas sem deficiência também sem motivação. Há acessibilidade arquitetônica, mas não atitudinal. Sempre teve acessibilidade arquitetônica. Uma vez, quando minha cadeira de rodas quebrou, eu morava em Mauá e o reparo era demorado e tive que levar a cadeira para arrumar em outro município. Peguei atestado e apresentei ao gestor. O mesmo falou que eu teria que compensar as horas. Isso me deixou muito nervosa, pois era o meio pelo qual eu trabalhava. Não consegui compensar e tive o desconto em folha de pagamento. Depois chamei o gestor para conversar e acionei o RH para fazer valer meu direito. Me senti lesada com a atitude dele. Minha realidade todos no trabalham conhecem: não dirijo, minha mãe não dirige e o gestor falou que não me trataria diferente dos demais. Respondi que não queria tratamento diferenciado, só queria fazer valer meu direito. Falta informação de tudo na empresa para os gestores. Falta senso do que a pessoas com deficiência realmente precisam.”

Quando questionada sobre a questão das cotas, é favorável. Acredita que se não houvesse lei, não haveria contratação de pessoas com deficiência nas empresas; devido ao estigma que a pessoa com deficiência tem.

\footnotetext{
Aluna F: "Se a Lei não existisse, as pessoas com deficiência não estariam inseridas no mercado de trabalho, pois existe o estigma da pessoa com deficiência fazer corpo mole. Existem funcionários preguiçosos tanto com deficiência quanto sem deficiência; não dá pra generalizar; se não houvesse a Lei as empresas não se adequariam e não contratariam. As empresas transfeririam para o Governo essa responsabilidade. Espero que um dia a Lei das cotas não seja mais necessária, que as empresas enxerguem a pessoa com deficiência com competência como qualquer outra.”
}

No quesito de cotas trabalhistas, quatro dos seis entrevistados usufruíram do sistema de cotas trabalhistas para adentrar em seus empregos; alguns mais intensamente, outros em poucas ocasiões. Isso remete a efetividade da Lei 8.213 de 1991 criada para garantir um percentual mínimo de pessoas com deficiência no quadro das empresas com mais de 100 funcionários. Esta lei tem sido tão eficaz que recentemente o Governo do Estado de São Paulo criou um prêmio para reconhecer as Melhores Empresas para a Pessoa com Deficiência trabalhar. Este 
prêmio está em seu segundo ano e é similar ao prêmio Melhores Empresas para se trabalhar, da Editora Abril.

O desconhecimento fez parte da trajetória de vida do aluno D. Inicialmente, aos 4 anos de idade foi diagnosticado que seu nervo óptico atrofiou; no entanto, este processo ocorreu desde seu nascimento, no entanto, seus pais não perceberam. Haveria possibilidade de reversão se o diagnóstico tivesse sido feito precocemente. Posteriormente, trabalhou em diversas empresas sem solicitar a contratação pelo sistema de cotas garantido por lei e participou de diversos concursos sem solicitar nenhum recurso especial devido a sua deficiência. Atualmente conhece seus direitos e tem a opinião que a divulgação melhorou muito nos últimos vinte anos.

Aluno D: “As leis melhoraram muito, estão divulgando os direitos das pessoas com deficiência, antigamente era só para deficiências especificas, isso melhorou muito. De uns 20 anos para cá melhorou muito. Eu acho que muitos ainda desconhecem seus direitos e benefícios e se intimidam com a deficiência devido ao preconceito.”

\subsection{Eixo Facilitadores e Barreiras}

Ao analisar o eixo sobre os facilitadores e barreiras que estes alunos enfrentaram em sua vida, é possível identificar pontos em comuns nas falas. A falta de preparo dos professores em geral é citada como barreira, assim como a divulgação incipiente dos serviços oferecidos pelas instituições para alunos com deficiência. Como facilitadores, é consenso em quase todos os entrevistados que os amigos foram essenciais no decorrer da trajetória.

O aluno A, que realizou seu doutorado nos Estados Unidos, comenta que o ledor disponibilizado naquela época foi um diferencial em relação ao Brasil. Na graduação pôde contar com o apoio de amigos para estudar e a digitalização de documentos facilitou demais a sua leitura. Atualmente lê em torno de 100 livros por ano. Por outro lado, como entrave, aponta o recurso do Portable Document Format (PDF) protector em diversos trabalhos acadêmicos, o que impede o uso do ledor. Entende a questão do plágio, porém acredita que deveriam existir outras formas de impedir a cópia e não um recurso que trava o documento e 
impede a leitura de uma pessoa com deficiência visual. Outro facilitador apontado pelo aluno A refere-se ao professor itinerante que teve até 1979 para aulas de reforço, porém este serviço foi cancelado na troca do governo na época. O aluno recorda com gratidão do professor: “Nas instituições não havia serviço especial, mas dispunha de um professor itinerante para aulas de reforço até 1979, professor Ilton Luis Macedo, que teve papel fundamental na minha educação. Este professor conhecia o sistema de leitura braile e trazia papel especial para braile nas aulas.

Há pesquisas que apontam o fato de que a atitude do professor é de suma importância para a permanência no processo escolar e para a integração do aluno com deficiência com os demais alunos (Moreira, 2005 \& Mittler, 2003).

Quando indagado sobre o termo pessoa com deficiência, mostra-se favorável a nomenclatura. Acredita que o termo portador denota um sentido negativo: "Sou contra portador, não levo a cegueira na mala. Dá a impressão que contamina. Cegueira não pega, só burrice pega.”

O aluno B, com deficiência auditiva, sempre realizou leitura orafacial; por isso, nunca solicitou nenhum serviço especializado junto ás instituições que estudou. Porém em vários momentos de sua trajetória acadêmica, os professores esqueciam de falar de frente para ele, a fim de que realizasse a leitura labial. Considera este fato um despreparo dos professores para lidar com alunos com deficiência auditiva. Por outro lado, este mesmo fato, proporcionou a ajuda de diversos amigos nas escolas que a todo momento lembravam os professores de falarem de frente para o aluno.

Os sentimentos de vergonha, orgulho e timidez também aparecem em trechos da entrevista:

\footnotetext{
Aluno B: "Não sei se não percebi que precisava, ou se me recusava a admitir isso... ou talvez tinha vergonha de pedir e ser tratado de forma diferente, não sei. Eu provavelmente deveria ter pedido um estenotipista...se pudesse voltar no tempo, pediria... a vaidade intelectual falou mais alto.. os colegas sempre empolgados, discutindo, e eu boiando... acho que a ficha não caiu, e eu tentava me virar do jeito que dava, mas na verdade não entendia direito as aulas.”
}

Por diversas vezes, o aluno participava de debates no doutorado. Para isso, era necessário estudar muito o tema com antecedência, pois muitas vezes não conseguia acompanhar os comentários dos colegas: “justamente por não conseguir compreender completamente o que estava sendo discutido nos debates... então, a solução foi me preparar muito bem para as 
aulas... e ter muita cara de pau... imagino que muitas vezes falei coisas que não tinham muito a ver com o assunto, mas faz parte. Imagino que eles nunca tiveram noção de quão pouco eu entendia os debates.”

Como dificuldade, na rotina do trabalho como professor, sinaliza que frequentemente precisa se aproximar dos alunos para entender o que dizem e tem dificuldade para participar de videoconferência, devido a péssima qualidade de som. Este fato inclusive fez com que desistisse de candidatar a um segundo mandato no conselho universitário.

Ao ser questionado sobre o termo atual de pessoas com deficiência, mostra-se favorável em relação ao termo anterior (portador de necessidades especiais):

\footnotetext{
Aluno B: "Portador de necessidades especiais tem um problema: a palavra "portar" transmite a ideia de que a deficiência é algo que eu carrego comigo, não é algo que faz parte de mim... como se fosse algo que eu pudesse colocar e tirar. Necessidades especiais me parece mais amplo. Pessoas com necessidades especiais pode ser uma boa, enfim, acredito que as palavras fazem diferença...”
}

O ingresso de alunos com necessidades educacionais especiais nos cursos superiores muitas vezes não se dá de modo explícito. “As dificuldades podem se revelar para a classe e para os professores paulatinamente. Há casos em que o próprio aluno desconhece sua condição ou não tem consciência das suas dificuldades.” (Ferrari \& Sekkel, 2007, p. 643). A aluna C por muito tempo achou que sua deficiência era um problema tratável de visão, desconhecendo sua deficiência e consequentemente seus direitos por muitos anos. Somente após um exame periódico em seu local de trabalho que foi levantada a hipótese de se tratar de deficiência, fato este confirmado após exames mais específicos. Neste período, a mesma estava na segunda faculdade. Antes de descobrir que tratava de uma deficiência, a mesma enfrentou dificuldades no trabalho, com números pequenos nos relatórios que analisava e também na primeira faculdade, onde sentava nos fundos e tinha problema para acompanhar a aula de forma integral. Após descobrir sua deficiência, a aluna começou a sentar na frente na sala de aula a fim de atenuar a dificuldade que possuía para acompanhar a aula e passou a utilizar lentes para aumentar o tamanho das letras. Além disto, solicitou que a faculdade disponibilizasse material em letras maiores, pedido este acatado pela instituição de forma imediata.

O aluno D possui perda visual de somente um olho e em nenhum momento solicitou serviço especial nas instituições que estudou. Como barreira, mencionou que a falta de divulgação 
dos direitos das pessoas com deficiência é um obstáculo para que o cidadão possa exercer seu direito pleno.

O aluno E menciona como facilitadores o piso plano, os elevadores e a biblioteca da FEA. Como barreira, sinaliza a rampa muito íngreme de acesso ao andar superior no prédio principal, onde ficava as salas dos professores. Além disto, no estacionamento principal não há cobertura, em dias de chuva, acaba se molhando. Considera a estrutura arquitetônica da FEA muito boa em termos gerais, no entanto, reclama do restante da USP; principalmente das calçadas e rampas: "Vários lugares não tem calçada, exemplo na praça dos bancos, há rampa, porém há um canteiro no meio da rampa, inviabilizando minha passagem.”

A aluna F aponta como facilitador a presença de uma professora, que a incentivou a fazer um estágio na época da faculdade. Pensou em desistir do processo, porém a professora a animou e a valorizou; fator crucial para seguir adiante no estágio. Em relação a época da faculdade, afirma que a universidade possuía rampas, elevadores, estacionamento reservado, ônibus na porta, próximo a estação de metrô; além dos professores e alunos serem bastante solícitos. Ressalta também sua atitude em não sentir medo e vergonha para pedir ajuda.

Com relação ao termo atual, pessoa com deficiência, é favorável em relação ao termo anterior, portador de necessidade especial:

\footnotetext{
Aluna F: “O termo foi alterado porque necessidade especial é muito genérico; por exemplo, minha mãe precisa tomar glicose, portanto, ela tem uma necessidade especial. O significado de deficiência é a alteração ou perda de uma funcionalidade; é isso que eu tenho. As pessoas precisam entender o que está por trás da deficiência. Acho necessidade especial mais preconceituoso, dá a impressão que eu sou diferente de você, que eu preciso de um super cuidado. Que eu sou diferente de você, em termos de capacidade. Se pensarmos por esse lado, a terminologia hoje está adequada.”
}

\subsection{Eixo Sugestões}

No último eixo, são mencionadas sugestões que os alunos fizeram visando a melhoria de suas condições de acesso e permanência na escola.

O aluno A menciona a necessidade da tecnologia ser cada vez mais difundida a fim de facilitar o aprendizado das pessoas com deficiência. No seu caso, por exemplo, permite que ele tenha acesso livre á toda literatura pela qual se interessa: “As condições melhoraram uns 
1.000 por cento. Nos anos 80 falava-se que os cegos não eram unidos, no entanto, hoje, com a tecnologia é possível a união e o acesso a qualquer tipo de material.”

Critica também a metodologia de ensino atualmente ser voltada para o visual somente: “ $O$ ensino não é visual somente, é necessário entender o processo cognitivo do aluno. Eu, por exemplo, ensino seno e cosseno dando exemplo de uma vara de pesca.” (Aluno A).

A respeito do processo cognitivo de cada aluno, o Aluno A critica escolas especiais que mesclam em suas salas, alunos com deficiências diferentes e consequentemente necessidades diferentes: “Acho uma irresponsabilidade crianças cegas convivendo em mesma sala de aula especial com crianças com déficit de cognição, por exemplo, pois a situação da criança cega torna-se ainda pior."(Aluno A).

Com relação ao acesso das pessoas com deficiência no ensino superior, acha que os números divulgados pelo Censo são errôneos, acredita que há muito mais pessoas com deficiência no ensino superior: "Julgo as estatísticas como deficitárias. No Censo que respondi, não perguntaram a mim se eu era cego, por exemplo." (Aluno A).

Com relação a sua passagem pela FEA, na época em que estudou na instituição, sugeriu uma série de melhorias a serem feitas: "colocar piso tátil, número da sala em braile na altura de uma pessoa, sinalizador de extintor, para não deixar o cego bater neles, de forma geral seguir a norma ABNT 5090.” (Aluno A).

O aluno B sugere a ampliação da divulgação dos serviços disponíveis na faculdade para estudantes com deficiência. Em sua passagem pela FEA, teve dificuldades para acompanhar algumas aulas, porém por desconhecer os serviços existentes, permaneceu com a barreira:

\footnotetext{
Aluno B: "Às vezes o aluno nem sabe do que precisa ou se precisa de algo, como foi meu caso, tem a questão da vergonha que as vezes impede a busca por ajuda. Se a Universidade mostrar os recursos e a tecnologia que possui despertará no aluno o interesse por buscar a ajuda. Se eu fosse pedir algo na universidade, nem saberia para quem pedir. O fato de ser aluno de fora também fez com que não pedisse ajuda. Nesta época, fazia aula de Análise de Balanços e tive muitas dificuldades, principalmente por ser de outra área”.
}

Diferentemente da opinião do aluno A, o aluno B acredita que mesma com a ajuda da tecnologia, o deficiente visual ainda tem mais dificuldades do que um aluno sem a deficiência: "As escolas não são práticas, um cego nunca terá o mesmo grau de acesso a 
materiais de leitura que um aluno vidente; mesmo utilizando de tecnologia de leitura, a velocidade de leitura nunca será a mesma que um aluno vidente.”

Outro ponto abordado pelo aluno B é a educação com qualidade desde o início da vida escolar: "A garantia à educação de qualidade precisa ser feita no início dos anos de estudo, não adianta providenciar ajuda na faculdade, se o aluno não teve isso antes; ele nem chegará lá, talvez por isso, tão poucas pessoas com deficiência conseguem chegar na faculdade.”

A aluna C menciona programas para conscientizar professores universitários a liderem com alunos com deficiência:

\footnotetext{
Aluno C: "Ações como falar de frente, devagar, escrever em letras maiores, disponibilizar os materiais de forma digital sem proteção são detalhes que passam despercebidos para alunos sem deficiência, mas que fazem toda a diferença para alunos com deficiência. São poucos professores que tomam este cuidado quando têm um aluno com deficiência em sala de aula, poucos prestam atenção nisso.”
}

Assim como o aluno $\mathrm{B}$, o aluno $\mathrm{D}$ também defende a divulgação dos serviços disponibilizados pelas faculdades:

Aluno B: "De uns 20 anos para cá melhorou muito a permanência dos alunos com deficiência na faculdade. No entanto, eu acho que muitos ainda desconhecem seus direitos e benefícios e se intimidam com a deficiência devido ao preconceito. Se houvesse mais informativos nas faculdades, despertaria o interesse em procurar mais ajuda."

O aluno universitário com necessidades educacionais especiais acumula vivências relacionadas às suas especificidades que devem ser consideradas pelos professores e um dos caminhos está na relação dialogada, que é condição real para a efetivação de uma prática pedagógica mais inclusiva. (Moreira, 2008, p. 14). 


\section{Considerações Finais}

Após a revisão da literatura feita sobre a legislação voltada para as pessoas com deficiência, o histórico das pessoas com deficiência, a análise dos dados referentes ao ensino superior, o programa existente na USP, as entrevistas com alunos com deficiência que passaram pela faculdade; pode-se extrair que houve evolução nos últimos anos em relação ao acesso e permanência deste público nas universidades. Os dados do Censo referente aos alunos com deficiência cursando um ensino superior no Brasil, mesmo que não sejam precisos e totalmente confiáveis, mostram a dimensão do crescimento exponencial que o país viveu nos últimos dez anos em relação á educação superior, em conformidade com os depoimentos dos alunos entrevistados em relação a melhoria nas condições.

No entanto, apesar dos avanços refletidos nas estatísticas em relação ao crescimento do acesso deste público, ao comparar o percentual da população cursando o ensino superior versus o total de deficientes no país ainda é ínfima esta parcela da população que cursa uma faculdade. Os dados de escolarização deste público ainda é menor em relação às pessoas sem deficiência, tanto em países desenvolvidos quanto em países em desenvolvimento. Ou seja, a lacuna existente entre ter ou não uma deficiência ainda é enorme no mundo inteiro.

O tema inclusão escolar passou a ser tratado com mais evidência nos últimos anos no meio acadêmico através de artigos voltados ao tema (conforme pesquisa bibliométrica que retrata aumento a cada ano), linhas de pesquisa criadas nas universidades e eventos sobre o tema difundidos pelo país, ou seja, a temática está em pauta nas principais universidades.

Do ponto de vista jurídico, uma gama de leis existem atualmente para garantir o direito á educação, ao acesso e a permanência nos cursos superiores. Os discursos dos políticos trazem atualmente a preocupação com o tema, a mídia divulga cada vez mais casos de sucesso e o próprio cidadão com deficiência está consciente sobre seus direitos básicos. No entanto, ainda não se comprova na prática a utilização de toda a população com deficiência de seus direitos. Por parte das autoridades, verificam-se muitos discursos políticos e poucas ações no sentido em se fazer cumprir com os ordenamentos jurídicos, dispositivos legais e normativos, os quais apóiam e defendem a todos o direito de igualdade, de ir e vir, de acessibilidade, de educação, assim como em relação a tantos outros direitos previstos em tais documentos. (Silva, 1987) 
O histórico evoluiu radicalmente, ao compararmos a forma pela qual as pessoas com deficiência eram tratadas antigamente e atualmente. Há uma mudança irreversível no sentido dos direitos e respeito adquiridos socialmente. O discurso dos ex alunos denota essa evolução, é possível afirmar que com informação e disposição, a pessoa com deficiência atualmente consegue trilhar caminhos de sucesso como qualquer cidadão.

No entanto, diante de tantas leis, tantos trabalhos e debates acadêmicos porque ainda existem números tão baixos de pessoas com deficiência no ensino superior? Este trabalho tentou responder essa questão através do relato da trajetória de vida de seis pessoas com deficiência que em algum momento de sua vida teve contato com a matéria de Contabilidade. É possível afirmar que os alunos entrevistados fazem parte de uma minoria de pessoas com deficiência que conseguiram concluir seu ensino superior; podem ser considerados como heróis, protagonistas de sua vida.

Pode-se apurar através dos relatos que as faculdades ainda precisam evoluir muito na qualidade dos serviços oferecidos para necessidades especiais, visto que os amigos aparecem como destaque nos principais facilitadores da vida acadêmica dos alunos e não a instituição de ensino. Além dos serviços oferecidos, é necessária uma divulgação maior das disponibilidades a fim de que os alunos com deficiência não se intimidem na busca por auxílio. Os professores também necessitam serem melhor preparados, seja através de capacitações técnicas como psicológicas, conforme é relatado em alguns dizeres dos entrevistados. Professores engajados no acolhimento dos alunos com deficiência tornam-se referências para estas pessoas e vice e versa. A inclusão traz ganhos para todos, tanto professores quanto alunos.

\footnotetext{
“A experiência de 12 anos em acompanhar o processo de inclusão de alunos universitários, particularmente com deficiências, tem demonstrado que esses alunos deixam marcas significativas pelos espaços e cursos que freqüentam e muitas vezes representam o imprevisível, o desconhecido. Ao mesmo tempo, sua presença é imprescindível, pois possui um acúmulo de vivências relacionadas às suas singularidades para aprender que deve ser conhecido e considerado pelos professores e colegas.” (Moreira, 2008, p. 16)
}

Por fim, também faz-se necessária uma fiscalização mais rígida dos serviços oferecidos, a fim de que seja medida a qualidade deste serviço, se realmente atende ao aluno com deficiência ou se somente cumpre uma lei. 


\begin{abstract}
“Apesar de os dados preliminares do censo escolar 2003 indicarem um salto educacional no número de alunos com necessidades educacionais matriculados no ensino regular, o desafio de uma educação inclusiva para essa população ainda está longe de ser atingida. Visto que, não são apenas os índices quantitativos que precisam ser alterados: a qualidade de sua educação está longe de ser inclusiva, pois há efetivamente muitas ausências na educação desses alunos. Falta concretizar políticas públicas que atendam e respeitem as suas especificidades, falta articular medidas específicas e ordinárias de atenção à diversidade e propostas de formação inicial e continuada aos professores que respondam adequadamente aos princípios inclusivos.” (Moreira, 2005, p. 6)
\end{abstract}

Ao tratar sobre o tema Educação Superior para pessoas com deficiência no Brasil, pode-se concluir que as conquistas e os direitos foram ampliados, o que é muito positivo, no entanto, ainda se apresenta longe do ideal. Há um vasto caminho a ser percorrido ainda. A frase de Norberto Bobbio, “a atitude do bom democrático é não se iludir com o melhor e não se resignar com o pior” (Bobbio, 1986, p.64) se encaixa com a situação da educação para as pessoas com deficiência no atual momento. Entende-se que o momento é de ascensão, longe do auge ainda.

\footnotetext{
"Uma universidade na perspectiva inclusiva não aparece de um momento para o outro. Não surge por decreto nem se configura por meio de uma única gestão administrativa. Pelo contrário, desenvolve-se ao longo de um processo de mudança que vai eliminando barreiras de toda ordem, desconstruindo conceitos, preconceitos e concepções segregadoras e excludentes que, muitas vezes camufladas pelo silêncio, parecem não existir. É um processo que nunca está finalizado, mas que, coletivamente, pode ser enfrentado. Uma universidade com atitude inclusiva é um grande desafio: sugere a desestabilização do instituído e o reconhecimento de que nossa sociedade é matizada pela diversidade, pela diferenciação e que o ser humano é pluralidade e não uniformidade.” (Moreira, 2008, p. 12)
}

Esta dissertação não pretende esgotar o assunto, mas, sim, provocar mais debates sobre o tema, principalmente na área de negócios, como Administração, Contabilidade e Economia, na qual não se encontrou trabalhos anteriores relacionados ao assunto. Espera-se que outros estudos sejam realizados sobre acesso e permanência dos alunos com deficiência na área de negócios. 


\section{REFERÊNCIAS $^{5}$}

Araújo, C. A. (2006, janeiro/junho). Bibliometria: evolução histórica e questões atuais. Em Questão, 12(1), 11-32.

Associação Brasileira de Normas Técnicas. (2004). NBR 9050: acessibilidade a edificações, mobiliário, espaços e equipamentos urbanos. Rio de Janeiro: Autor.

Bardin, L. (1977). Análise de Conteúdo. Lisboa: Edições 70.

Beyer, H. O. (2004). O pioneirismo da escola (modelo) Flämming na proposta de integração (inclusão) escolar na Alemanha: aspectos pedagógicos decorrentes. In: Reunião ANPED, 2.

Bishop, M. \& Boden, R. (2008). Disabling accounting. Critical Perspective on Accounting, 19(2), 1-16.

Bobbio, N. (1986). O Futuro da Democracia: Uma defesa das regras do jogo (2a ed.). Rio de Janeiro: Paz e Terra.

Castilho, A. M. C. (2012). Caracterização das condições de acessibilidade previstas para o acadêmico com necessidades educacionais especiais nas instituições públicas de Ensino Superior do Estado do Paraná. Dissertação de Mestrado, Psicologia, Universidade Estadual de Maringá, PR.

Constituição da República Federativa do Brasil. (1891). Rio de Janeiro: Senado. Recuperado em 04 de junho de 2014, de www.planalto.gov.br/ccivil_03/constituicao/constituicao91.htm

Constituição da República Federativa do Brasil. (1937). Rio de Janeiro: Senado. Recuperado em 04 de junho de 2014, de www.planalto.gov.br/ccivil_03/constituicao/constituicao37.htm

Constituição da República Federativa do Brasil. (1967). Brasília: Senado. Recuperado em 04 de junho de 2014, de www.planalto.gov.br/ccivil_03/constituicao/constituicao67.htm

\footnotetext{
${ }^{5}$ De acordo com as normas da American Psychology Association (APA).
} 
Constituição da República Federativa do Brasil. (1988). Brasília: Senado. Recuperado em 04 de junho de 2014, de www.planalto.gov.br/ccivil_03/constituicao/constituicao88.htm

Declaração Universal dos Direitos Humanos. (1990). Jomtien, Tailandia: Organização das Nações Unidas. Recuperado em 16 de junho de 2013, de www.unicef.org/brazil/pt/resources_10230.htm

Decreto Federal n. 5.296. (2004, 2 de dezembro). Ministério da Educação. Estabelece normas gerais e critérios básicos para a promoção da acessibilidade das pessoas portadoras de deficiência ou com mobilidade reduzida, e dá outras providências. Brasília. Recuperado em 10 de junho de 2014, de www.planalto.gov.br/ccivil_03/_ato20042006/.../decreto/d5296.htm

Dicionário Michaelis. Recuperado em 22 de janeiro de 2013, em http://michaelis.uol.com.br/moderno/portugues/index.php

Duff, A. \& Ferguson, J. (2007). Disability and accounting firms: evidences from the UK. Critical Perspectives on Accounting, 18(2), 139-157.

Duff, A. \& Ferguson, J. (2011). Disability and the socialization of accounting professionals. Critical Perspective on Accounting, 22(1), 351-364.

Duff, A., Ferguson J. \& Gilmore, K. (2007). Issues concerning the employment and employability of disabled people in UK accounting firms: An analysis of the views of human resource managers as employment gatekeepers. The British Accountin Review, 39(01), 15-38.

Faculdade de Economia, Administração e Contabilidade, História. (2014). Recuperado em 22 de dezembro de 2014, de http://www.fea.usp.br/conteudo.php?i=4

Ferrari, M. A. L. D. \& Sekkel, M. C. (2007). Educação Inclusiva no Ensino Superior: um novo desafio. Psicologia Ciência e Profissão, Instituto de Psicologia, Universidade de São Paulo, p. 636-647

Figueira, E. (2008). Caminhando em silêncio: Uma introdução à trajetória das pessoas com deficiência na história do Brasil. São Paulo: Giz Editorial e Livraria Ltda. 
Fortes, V. G. G. F. (2005). A inclusão da pessoa com deficiência visual na UFRN: a percepção dos acadêmicos. Dissertação de Mestrado, Escola de Educação, Universidade Federal do Rio Grande do Norte, Natal.

Gois, A. (2009, 11 de maio). Cota não garante inclusão de aluno deficiente. Jornal Folha de São Paulo, Caderno Cotidiano, p. 3.

Jannuzzi, G. M. (1997). As políticas e os espaços para criança excepcional. In: Freitas, M. C. (Org). História social da infância no Brasil. São Paulo: Cortez.

Laplane, A. (2006 outubro). Uma análise das condições para a implementação de políticas de educação inclusiva no Brasil e na Inglaterra. Educação e Sociedade, 27(96), 689-715.

Lei n. 7.853. (1989, 24 de outubro). Dispõe o apoio às pessoas portadoras de deficiência, sua integração social, sobre a Coordenadoria Nacional para Integração da Pessoa Portadora de Deficiência - Corde, institui a tutela jurisdicional de interesses coletivos ou difusos dessas pessoas, disciplina a atuação do Ministério Público, define crimes, e dá outras providências. Diário Oficial da União, Brasília. Recuperado em 12 de junho de 2014, de www.planalto.gov.br/ccivil_03/leis/17853.htm

Lei n. 8.213. (1991, 24 de julho). Dispõe sobre os Planos de Benefícios da Previdência Social e dá outras providências. Diário Oficial da União, Brasília. Recuperado em 14 de junho de 2014, de www.planalto.gov.br/ccivil_03/leis/l8213cons.htm

Lei de Diretrizes e Bases da Educação Nacional n. 9.394. (1996, 20 de dezembro). Estabelece as diretrizes e bases da educação nacional. Brasília. Recuperado em 10 de junho de 2014, de www.planalto.gov.br/ccivil_03/leis/19394.htm

Lei n. 10.172 (2001, 09 de janeiro). Plano Nacional de Educação (PNE). Aprovação do Plano Nacional de Educação e outras providências. Ministério da Educação, Brasília. Recuperado em 13 de junho de 2014, de www.planalto.gov.br/ccivil_03/leis/leis_2001/l10172.htm

Lei n. 10.436. (2002, 24 de abril). Dispõe sobre a Língua Brasileira de Sinais - Libras e dá outras providências. Diário Oficial da União, Brasília. Recuperado em 6 de junho de 2014, de www.planalto.gov.br/ccivil_03/leis/2002/110436.htm

Lei n. 11.096. (2005, 13 de janeiro). Institui o Programa Universidade para Todos - PROUNI. Diário Oficial da União, Brasília. Recuperado em 6 de junho de 2014, de www.planalto.gov.br/ccivil_03/_ato2004-2006/2005/lei/L11096.htm 
Magalhães, R.C. (2010). Ensino Superior no Brasil e inclusão de alunos com deficiência. In: Mendes, E. G. (Org.), Tramas entre Deficiência, Estado e Educação: algumas reflexões a partir do contexto francês. CNPQ. Anped.

Maiola, C. S., Boos, F. \& Fischer, J. (2008). Inclusão na Universidade sob a ótica dos acadêmicos com necessidades especiais: possibilidades e desafios. Ponto de Vista 1 (10), 79-93.

Martins, V. S. B. (2012). O REUNI na UFMA e o favorecimento do acesso de alunos com deficiência ao ensino superior: questões para reflexão. Dissertação de Mestrado, Facudade de Educação, Universidade Federal do Maranhão, São Luís.

Mazzotta, M. J. S. (2005). Educação Especial no Brasil: história e políticas públicas (5a ed). São Paulo: Cortez.

Memória USP: 80 anos de história. (2013). Recuperado em 20 de dezembro de 2014, de http://www5.usp.br/institucional/a-usp/historia/linha-do-tempo/

Mendes, E. G. (2010). Tramas entre deficiência, estado e educação: algumas reflexões a partir do contexto francês. CNPq. Anped.

Miranda, T. G. \& Galvão Filho, T. A. (Orgs.). (2012). O professor e a educação inclusão: formação, práticas e lugares. Salvador: EDUFBA.

Mittler, P. (2003). Educação inclusiva: contextos sociais. (W. Brazão, trad.). Porto Alegre: Artmed.

Moehlecke, S. (2004). Fronteiras da igualdade no ensino superior: excelência e justiça racial. Tese de Doutorado, Faculdade de Educação, Universidade de São Paulo, São Paulo.

Moreira, L. C. (2005). In(ex)clusão na universidade: o aluno com necessidades educacionais especiais em questão. Revistas Educação da Universidade de Santa Maria, (25), 1-10.

Moreira, L. C. (2008). Acesso e permanência de pessoas com necessidades especiais no ensino superior. Ponto de Vista, 1(10), 11-17.

Moreira, L. C. \& Stroparo, E. M. (2013). Educação Inclusiva no Ensino Superior: análise bibliométrica na produção de teses e dissertações. In: VIII Encontro da Associação 
Brasileira de Pesquisadores em Educação Especial (p. 993-1003). Londrina, PR: Editora da UEL.

Nadal, P. (2011). O que são os Transtornos Globais do Desenvolvimento (TGD)? Revista Nova Escola. Recuperado em 03 de fevereiro de 2013, de http://revistaescola.abril.com.br/inclusao/educacao-especial/transtornos-globaisdesenvolvimento-tgd-624845.shtml

Nogueira, N. I. (2003). A educação de pessoas com desordens do espectro autístico e dificuldades semelhantes de aprendizagem. Temas sobre desenvolvimento, 12(68), 545 .

Oliveira, J. A. K. (2008). Políticas de cotas em universidades públicas: igualdades e desigualdades no aspecto social da constituição. Fap Ciência. Faculdade de Apucarana. Recuperado em 04 de fevereiro de 2015, de http://www.fap.com.br/fapciencia/002/edicao_2008/008.pdf

Oliven, A.C. (1992). Origem, características e desenvolvimento dos sistema de ensino superior no Brasil. In: Morosoni M.; Leite, D. Universidade e integração no cone sul. Porto Alegre: Ed. das UFRGS.

Política Nacional de Educação Especial (PNEE). (1994). Ministério da Educação. Secretaria de Educação Especial. Orientação sobre o processo de integração instrucional. Brasília. Recuperado em 11 de junho de 2014, de portal.mec.gov.br/arquivos/pdf/politicaeducespecial.pdf

Portaria n. 3.284. (2003, 7 de Novembro). Ministério da Educação. Dispõe sobre requisitos de acessibilidade de pessoas portadoras de deficiências, para instruir os processos de autorização e de reconhecimento de cursos, e de credenciamento de instituições. Brasília. Recuperado em 11 de junho de 2014, de portal.mec.gov.br/seesp/arquivos/pdf/port3284.pdf

Relatório de Indicadores de Ciência, Tecnologia e Inovação em São Paulo. (2010). São Paulo, Brasil: Fundação de Amparo à Pesquisa do Estado de São Paulo - FAPESP

Relatório Mundial sobre a Deficiência. (2011). São Paulo, Brasil: Secretaria dos Direitos de Pessoas com Deficiência.

Resolução A/61/611. (2006, 06 de dezembro). Convenção sobre o direito das pessoas com deficiência. Brasília. Recuperado em 07 de junho de 2014, de www.planalto.gov.br/ccivil_03/_ato2007-2010/2009/.../d6949.htm 
Rey, F. G. (2010). Pesquisa Qualitativa e Subjetividade: os processos de construção da informação. São Paulo: Cengage Learning.

Rocha, T. B. \& Miranda, T. G. (2009, maio/ agosto). Acesso e permanência do aluno com deficiência na instituição de ensino superior. Revista Educação Especial, 22(34), 197212.

Rossetto, E. (2009). Sujeitos com deficiência no ensino superior: vozes e significados. Tese de Doutorado, Faculdade de Educação, Universidade Federal do Rio Grande do Sul, Porto Alegre.

Roulstone, A \& Williams, J. (2013). Being disabled, being a manager: 'glass partitions' and conditional identities in the contemporary workplace. Disability and Society, 29(1), 16-29.

Santos, J. B. (2012). Inclusão e preconceito na universidade: possibilidades e limites para estudantes com deficiência. In T. G. Miranda \& T. A. Galvão Filho (Orgs.), $O$ professor e a educação inclusão: formação, práticas e lugares (pp. 385-402). Salvador: EDUFBA.

Sassaki, R. K. (1997). Inclusão: construindo uma sociedade para todos (3 ${ }^{\mathrm{a}}$ ed). Rio de Janeiro: WVA.

Silva, A.P., Barros, C. R., Nogueira, M. L. M \& Barros, V.A. (2007). Conte-me sua história: reflexões sobre o método de História de Vida. Mosaico Estudos em Psicologia, 1 (1), 25-35.

Silva, O. M. (1987). A epopeia ignorada. São Paulo: CEDAS Centro São Camilo de Desenvolvimento em Administração da Saúde.

Spindola, T. \& Santos, R. S. (2003).Trabalhando com a história de vida: percalços de uma pesquisa(dora?). Revista Escola Enfermagem USP, 37(2), 119-126.

USP Legal, Universidade de São Paulo. (2010). Recuperado em 23 de dezembro de 2014, de http://www.prceu.usp.br/programas/usplegal/pc_usplegal.php

Valdes, M.T.M. (Org) (2006). Inclusão de pessoas com deficiência no ensino superior no Brasil: caminhos e desafios. Fortaleza: EDUECE. 


\section{APÊNDICES}

APÊNDICE A - Termo de Consentimento Livre e Esclarecido

Concordo em participar, como voluntário, do estudo que tem como pesquisador responsável o(a) aluno(a) de pós graduação Cristina Linares Cintra de Carvalho do curso de Mestrado em Ciências Contábeis e Controladoria da Universidade de São Paulo, no. USP 3486680, que pode ser contatado pelo e-mail crislinares@usp.br e pelos telefones (11) 989410344 e (11) 99670 8100. Tenho ciência de que o estudo tem em vista realizar entrevistas com (ex) alunos, visando, por parte do(a) referido(a) aluno(a) a realização de um trabalho de conclusão de mestrado. Minha participação consistirá em conceder uma entrevista que será gravada e transcrita. Entendo que esse estudo possui finalidade de pesquisa acadêmica, que os dados obtidos serão divulgados, preservando o anonimato dos participantes, assegurando assim minha privacidade. Além disso, sei que posso abandonar minha participação na pesquisa quando quiser e que não receberei nenhum pagamento por esta participação.

Assinatura ou De Acordo via email

São Paulo, de de 20 


\section{APÊNDICE B - Roteiro}

1) Nome, sexo, idade, trajetória educacional, profissional, deficiência

2) Como foi o processo de escolha do curso? Por que escolheu o curso de contabilidade? Por que escolheu a profissão em contabilidade? A deficiência em algum momento impactou ou influenciou em sua decisão?

3) Quais os momentos mais difíceis ou críticos que enfrentou em sua trajetória no ensino superior? O que ajudou a superá-los? Conte como foi cada etapa. Em algum momento, teve apoios especiais na escola/ vestibular/ faculdade/ trabalho? Poderia descrever essa situação? Como ela impactou sua trajetória no ensino superior ou na profissão? Em algum momento, sofreu discriminação na escola/ vestibular/ faculdade/ trabalho? Poderia descrever essa situação? Como ela impactou sua trajetória no ensino superior ou na profissão?

4) Quais os momentos mais difíceis ou críticos que enfrentou em sua trajetória de ingresso na profissão? O que ajudou a superá-los? Conte como foi cada etapa. Como a deficiência impacta seu trabalho em contabilidade? Como você se diferencia no que faz?

5) Em sua opinião qual o impacto das leis voltadas para garantir cotas no trabalho e na faculdade?

6) Como você vê o processo de promoção em sua empresa? Quais os meios para alcançá-la?

7) Como são definidos os salários na empresa em que trabalha? Em algum momento, recebeu um salário inferior a um par em seu trabalho? Qual a justificativa para isso?

8) $\mathrm{Na}$ era do capital intelectual, como pessoas com necessidades especiais poderiam contribuir para as empresas? E para a sociedade?

9) Como a contabilidade poderia atuar para ajudar na inclusão de pessoas com necessidades especiais?

10) Acha adequada a nomenclatura Pessoa com Deficiência? Prefere o termo anterior: portadora de necessidades especiais?

11) Tem alguma informação ou situação que gostaria de adicionar ou descrever? 